\title{
Class I Cultural Resource Overview for Oil Shale and Tar Sands Areas in Colorado, Utah, and Wyoming
}

Prepared for:

U.S. Department of the Interior, Bureau of Land Management

Prepared by:

Argonne National Laboratory

November 2007

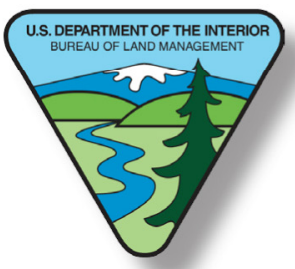





\section{Class I Cultural Resource Overview for Oil Shale and Tar Sands Areas in Colorado, Utah, and Wyoming}

Prepared for:

U.S. Department of the Interior,

Bureau of Land Management

Prepared by:

Dan O'Rourke, Doug Kullen, Lynn Gierek, Konnie Wescott, Matt Greby, Georgia Anast, Matt Nesta, Lee Walston, Robert Tate, Alison Azzarello, Bill Vinikour, Bob Van Lonkhuyzen, John Quinn, and Ron Yuen Environmental Science Division, Argonne National Laboratory

November 2007 



\section{CONTENTS}

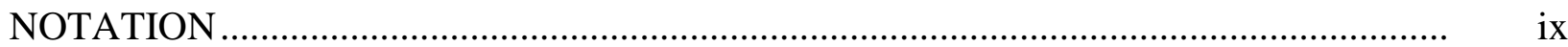

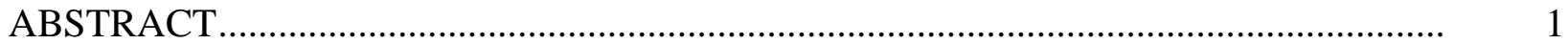

1 INTRODUCTION AND SCOPE ................................................................. 2

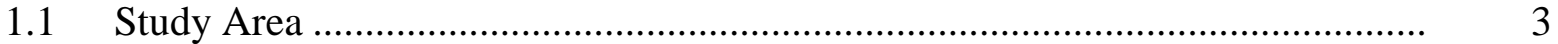

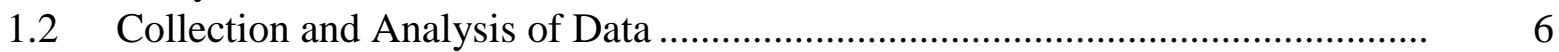

1.2.1 BLM and the Management of Cultural Resources ............................ 6

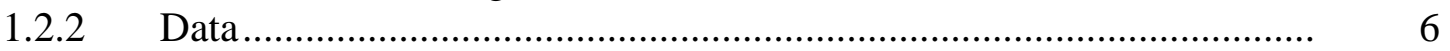

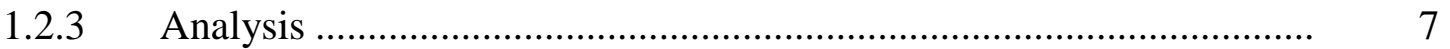

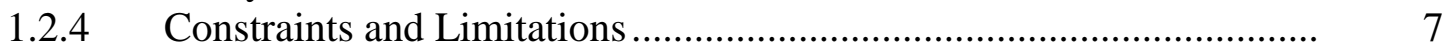

1.2.4.1 Colorado.......................................................................... 8

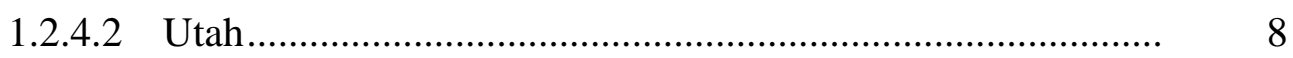

1.2.4.3 Wyoming........................................................................ 8

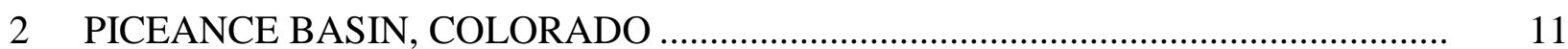

$2.1 \quad$ Environmental Setting ......................................................................... 11

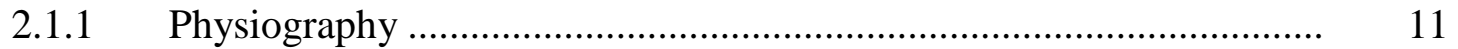

2.1.2 Geology, Soils, and Hydrology...................................................... 11

2.1.3 Climate, Flora, and Fauna .............................................................. 12

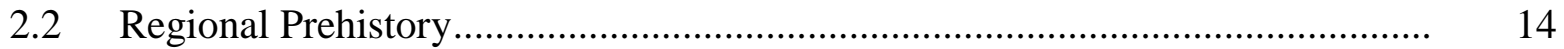

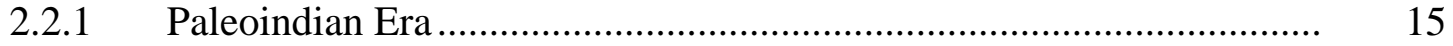

2.2.2 Archaic Era ............................................................................. 16

2.2.2.1 Pioneer Period ............................................................. 17

2.2.2.2 Settled Period .................................................................... 18

2.2.2.3 Transitional Period ................................................................ 18

2.2.2.4 Terminal Period ................................................................ 18

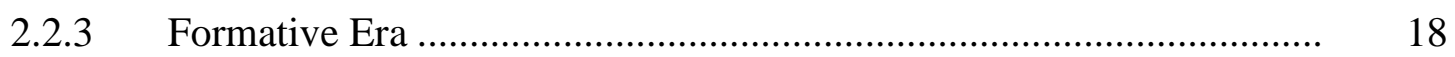

2.2.3.1 Fremont Tradition ....................................................... 19

2.2.3.2 Aspen Tradition ............................................................ 20

2.2.4 Protohistoric Era .................................................................... 20

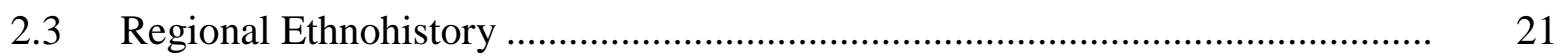

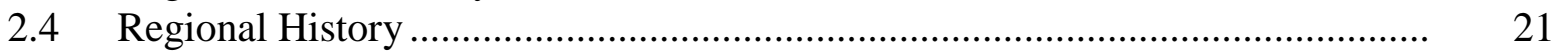

2.4.1 Early Explorations and Fur Trade.................................................... 21

2.4.2 Ute-Euroamerican Conflicts ........................................................... 23

2.4.3 Cattle and Sheep Industries.............................................................. 24

2.4.4 Coal and Oil Exploration ............................................................... 25

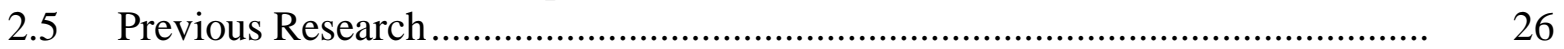

2.5.1 Surveys and Overviews .................................................................. 26

2.5.2 General Observations.................................................................. $\quad 34$

2.5.2.1 Rock Shelters .............................................................. 34 


\section{CONTENTS (Cont.)}

2.5.2.2 Wickiup Camps................................................................. 35

2.5.2.3 Fire Suppression and Architectural Sites ............................... $\quad 35$

2.5.2.4 Effectiveness of Predictive Models ...................................... 36

2.5.2.5 Avoidance Option ............................................................. 37

2.6 Recorded Sites

3 UINTA BASIN AND SPECIAL TAR SANDS AREAS, UTAH ……….................... 41

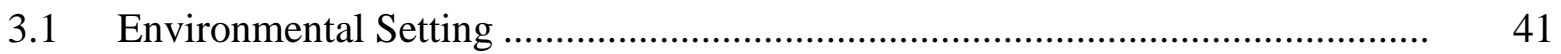

3.1.1 Physiography ........................................................................... 41

3.1.2 Geology, Soils, and Hydrology …………………………………...... 41

3.1.3 Climate, Flora, and Fauna..................................................................... 43

3.2 Regional Prehistory.................................................................................. 44

3.2.1 Paleoindian Period ......................................................................... 44

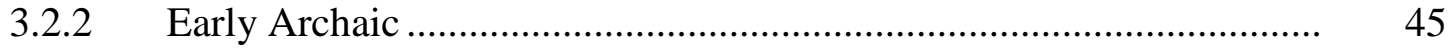

3.2.3 Middle Archaic ........................................................................... 46

3.2.4 Late Archaic............................................................................... 46

3.2.4.1 Formative Era................................................................... 47

3.2.4.2 Ancestral Puebloan .............................................................. 49

3.2.5 Shoshonean Era.......................................................................... 52

3.3 Regional Ethnohistory …………............................................................... 52

$3.4 \quad$ Regional History .......................................................................................... 53

3.4.1 Exploration and the Fur Trade .......................................................... 53

3.4.2 Farming and Ranching................................................................... 54

3.4.3 Mining ....................................................................................... 54

3.5 Previous Research ..................................................................................... 55

3.5.1 Uinta Basin ............................................................................... 55

3.5.1.1 Surveys and Overviews..................................................... 55

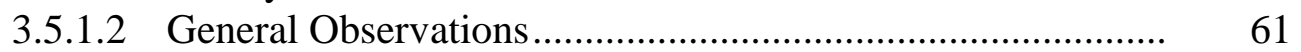

3.5.2 Special Tar Sand Areas.......................................................................... 63

3.5.2.1 Surveys and Overviews....................................................... 63

3.5.2.2 General Observations......................................................... 66

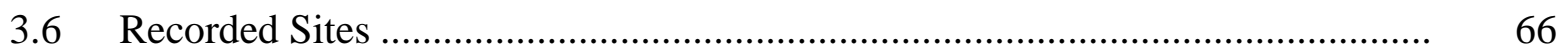

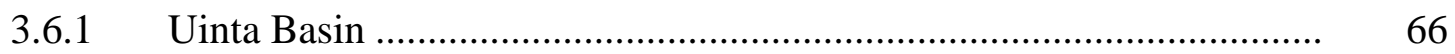

3.6.2 Special Tar Sand Areas..................................................................... 69

4 GREEN RIVER AND WASHAKIE BASINS, WYOMING ……………………..........

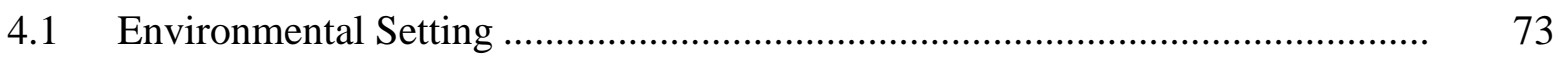

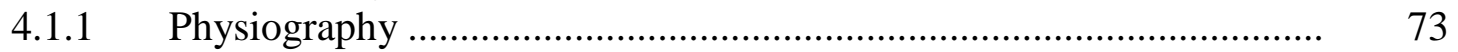

4.1.2 Geology, Soils, and Hydrology......................................................... 73

4.1.3 Climate, Flora, and Fauna..................................................................... $\quad 74$ 


\section{CONTENTS (Cont.)}

$4.2 \quad$ Regional Prehistory........................................................................................ $\quad 76$

4.2.1 Paleoindian Period ............................................................................ $\quad 76$

4.2.2 Archaic Period ............................................................................. 77

4.2.2.1 Early Archaic .................................................................... $\quad 78$

4.2.2.2 Late Archaic .................................................................... 78

4.2.3 Late Prehistoric Period...................................................................... 79

4.2.4 Protohistoric Period ...................................................................... $\quad 80$

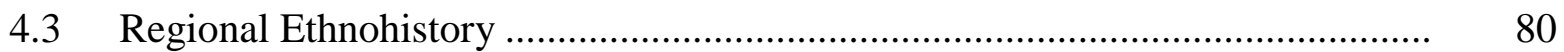

4.4 Regional History .............................................................................. 81

4.4.1 Early Exploration and Fur Trading ……………….............................. 81

4.4.2 Settlement and Transportation ............................................................ 83

4.4.3 Oil and Coal Mining ....................................................................... 86

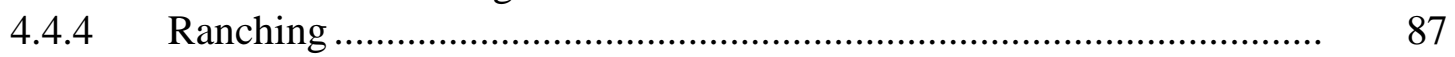

4.5 Previous Research ....................................................................................... 87

4.5.1 Surveys and Overviews ................................................................... 87

4.5.1.1 Green River Basin................................................................ $\quad 89$

4.5.1.2 Washakie Basin................................................................. 91

4.5.2 General Observations................................................................. 92

4.5.2.1 More Surveys, Smaller Surveys........................................... $\quad 92$

4.5.2.2 Effectiveness of Existing Predictive Models ......................... 93

4.6 Recorded Sites ................................................................................... 93

5 DATA GAPS, RESEARCH QUESTIONS AND PRIORITIES, AND MANAGEMENT RECOMMENDATIONS …………………......................... 97

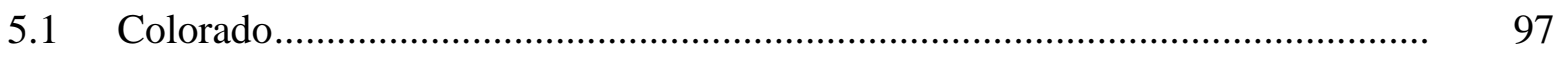

5.1.1 Gaps in the Archaeological Record ..................................................... 97

5.1.2 Research Questions and Priorities ....................................................... 99

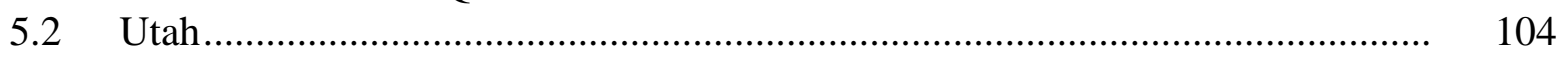

5.2.1 Gaps in the Archaeological Record .................................................. 104

5.2.2 Research Questions and Priorities ....................................................... 105

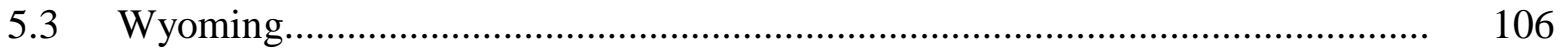

5.3.1 Southwestern Wyoming Archaeological Community .......................... 106

5.3.2 Gaps in the Archaeological Record ...................................................... 106

5.3.3 Research Questions and Recommendations ........................................ 107

5.3.3.1 Research Questions and Priorities ........................................ 108

5.3.3.2 Recommendations........................................................... 110

$5.4 \quad$ Management Recommendations .................................................................... 111

5.4.1 Regional Synthesis of CRM Data ...................................................... 111

5.4.2 Significance of Small Sites ............................................................... 112

5.4.3 Paleoenvironmental Reconstruction of Prehistoric 112

5.4.4 Geomorphological Context and Deeply Buried Site Discovery ........... 112 


\section{CONTENTS (Cont.)}

5.4.5 Site Management Priorities................................................................... 113

5.4.6 Use Categories .................................................................................. 113

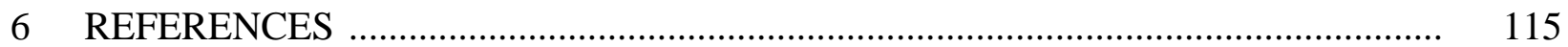

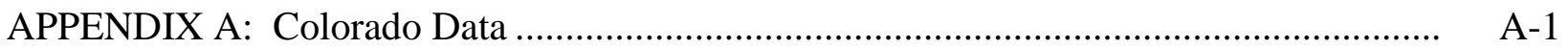

APPENDIX B: Utah Data................................................................................ B-1

APPENDIX C: Wyoming Data …………………................................................. C-1

APPENDIX D: Sensitivity Maps................................................................................ D-1

\section{TABLES}

2-1 Excavated Sites in the Piceance Basin ................................................................. 38

A-1 Colorado Cultural Resource Surveys, Piceance Basin, Colorado.............................. A-3

A-2 Colorado Cultural Resources, Piceance Basin, Colorado ……………………........... A-70

A-3 Colorado Site Types.......................................................................................... A-139

A-4 NRHP Status of Cultural Resources in the Piceance Basin, Colorado ...................... A-139

B-1 Utah Oil Shale Cultural Resource Surveys ……………………………………...... B-3

B-2 Utah Tar Sands Cultural Resource Surveys ............................................................. B-84

B-3 Cultural Resources in Oil Shale Area, Uinta Basin, Utah ....................................... B-105

B-4 NRHP Status of Cultural Resources in the Utah Project Area ................................ B-138

B-5 Cultural Resources in Special Tar Sand Areas ....................................................... B-139

B-6 Prehistoric Site Types in Utah Tar Sands Areas ...................................................... B-158

B-7 Historic Site Affiliation, Special Tar Sand Areas …………………………........... B-159

C-1 Cultural Resource Surveys, Green River Basin, Wyoming ....................................... C-3 


\section{TABLES (Cont.)}

C-2 Cultural Resource Surveys, Washakie Basin, Wyoming

C-3 Cultural Resources, Green River Basin, Wyoming C-138

C-4 Cultural Resources, Washakie Basin, Wyoming

C-5 Site Types and Counts, Green River Basin, Wyoming. C-534

C-6 Site Types and Counts, Washakie Basin, Wyoming.

C-7 NRHP Status of Cultural Resources in the Green River Basin, Wyoming C-541

C-8 NRHP Status of Cultural Resources in the Washakie Basin, Wyoming ......

D-1 Identification of Soil Types by Basin and the Probability of Site Presence for Oil Shale Basins

D-2 Identification of Soil Types by Basin and the Probability of Site Presence for Special Tar Sand Areas

D-3 Chi-Square Distribution of Cultural Sites across Soil Types for Oil Shale Basins

D-4 Chi-Square Distribution of Cultural Sites across Soil Types for Special Tar Sand Areas....

\section{FIGURES}

1-1 Map of the Most Geologically Prospective Oil Shale Resources within the Green River Formation Basins in Colorado, Utah, and Wyoming

1-2 Special Tar Sand Areas in Utah .............................................................

2-1 Cultural Resource Surveys in the Piceance Basin, Northwestern Colorado............. 28

2-2 Cultural Resources in the Piceance Basin, Northwestern Colorado ........................ 39

3-1 Cultural Resource Surveys in the Uinta Basin, Northeastern Utah ....................... 58

3-2 Cultural Resource Surveys in the Special Tar Sand Areas, Utah. .......................... 64 


\section{FIGURES (Cont.)}

3-3 Cultural Resources in the Uinta Basin, Northeastern Utah........................................ 67

3-4 Cultural Resources in the Special Tar Sand Areas, Utah.......................................... 70

4-1 Cultural Resource Surveys in the Green River and Washakie Basins, Southwestern Wyoming

4-2 Cultural Resources in the Green River and Washakie Basins, Southwestern Wyoming ..................................................................................

D-1 Probability of Presence of Cultural Resources in the Piceance Basin, Colorado ...... D-4

D-2 Probability of Presence of Cultural Resources in the Uinta Basin, Utah.................. D-5

D-3 Probability of Presence of Cultural Resources in the Green River and Washakie Basins, Wyoming .......................................................................... D D-6

D-4 Probability of Presence of Cultural Resources in the Special Tar Sand Areas in Utah

D-7 


\section{NOTATION}

The following is a list of the acronyms, initialisms, and abbreviations (including units of measure) used in this document.

\section{ACRONYMS, INITIALISMS, AND ABBREVIATIONS}

APE area of potential effect

BLM Bureau of Land Management

BYU Brigham Young University

CIG Colorado Interstate Gas

CRM Cultural Resource Management

CSU Colorado State University

DOI U.S. Department of Interior

FLPMA Federal Land Policy and Management Act

GIS geographic information system

IMAC Intermountain Antiquities Computer System

LOPA Laboratory of Public Archaeology

MAPCO Mid-America Pipeline Company

NEPA National Environmental Policy Act

NHPA National Historic Preservation Act

NRHP National Register of Historic Places

PA Programmatic Agreement

PEIS programmatic environmental impact statement

P.L. Public Law

RD\&D research, development, and demonstration

SHPO State Historic Preservation Office

STSA Special Tar Sand Area

USC United States Code

USGS U.S. Geological Survey

WYCRO Wyoming Cultural Records Office 


\section{UNITS OF MEASURE}

ac-ft acre-foot (feet)

$\mathrm{ft}$ foot (feet)

m meter(s)

$\mathrm{m}^{2} \quad$ square meter(s)

mi mile(s)

gal gallon(s)

$\mathrm{mi}^{2} \quad$ square mile(s)

in. inch(es)

yr year(s) 


\title{
CLASS I CULTURAL RESOURCE OVERVIEW FOR OIL SHALE AND TAR SANDS AREAS IN COLORADO, UTAH, AND WYOMING
}

\author{
prepared by \\ Dan O’Rourke, Doug Kullen, Lynn Gierek, Konnie Wescott, Matt Greby, Georgia Anast, \\ Matt Nesta, Lee Walston, Robert Tate, Alison Azzarello, Bill Vinikour, \\ Bob Van Lonkhuyzen, John Quinn, and Ron Yuen \\ Environmental Science Division \\ Argonne National Laboratory \\ Argonne, Illinois
}

\begin{abstract}
In August 2005, the U.S. Congress enacted the Energy Policy Act of 2005, Public Law 109-58. In Section 369 of this Act, also known as the "Oil Shale, Tar Sands, and Other Strategic Unconventional Fuels Act of 2005," Congress declared that oil shale and tar sands (and other unconventional fuels) are strategically important domestic energy resources that should be developed to reduce the nation's growing dependence on oil from politically and economically unstable foreign sources. The Bureau of Land Management (BLM) is developing a Programmatic Environmental Impact Statement (PEIS) to evaluate alternatives for establishing commercial oil shale and tar sands leasing programs in Colorado, Wyoming, and Utah. This PEIS evaluates the potential impacts of alternatives identifying BLM-administered lands as available for application for commercial leasing of oil shale resources within the three states and of tar sands resources within Utah. The scope of the analysis of the PEIS also includes an assessment of the potential effects of future commercial leasing. This Class I cultural resources study is in support of the Draft Oil Shale and Tar Sands Resource Management Plan Amendments to Address Land Use Allocations in Colorado, Utah, and Wyoming and Programmatic Environmental Impact Statement and is an attempt to synthesize archaeological data covering the most geologically prospective lands for oil shale and tar sands in Colorado, Utah, and Wyoming. This report is based solely on geographic information system (GIS) data held by the Colorado, Utah, and Wyoming State Historic Preservation Offices (SHPOs). The GIS data include the information that the BLM has provided to the SHPOs. The primary purpose of the Class I cultural resources overview is to provide information on the affected environment for the PEIS. Furthermore, this report provides recommendations to support planning decisions and the management of cultural resources that could be impacted by future oil shale and tar sands resource development.
\end{abstract}




\section{INTRODUCTION AND SCOPE}

The U.S. Department of the Interior (DOI), Bureau of Land Management (BLM), administers approximately 261 million acres of public lands in the United States. This administrative responsibility must address stewardship, conservation, and resource use, including the development of energy resources in an environmentally sound manner. Management of these public lands must be conducted in accordance with the requirements of the Federal Land Policy and Management Act of 1976 (FLPMA) (United States Code, Title 43, Section 1701 et seq. [43 USC 1701 et seq.]).

In August 2005, the U.S. Congress enacted the Energy Policy Act of 2005, Public Law (P.L.) 109-58. In Section 369 of this Act, also known as the "Oil Shale, Tar Sands, and Other Strategic Unconventional Fuels Act of 2005," Congress declared that oil shale and tar sands (and other unconventional fuels) are strategically important domestic energy resources that should be developed to reduce the nation's growing dependence on oil from politically and economically unstable foreign sources. In addition, Congress declared that both research- and commercial-scale development of oil shale and tar sands should (1) be conducted in an environmentally sound manner using management practices that will minimize potential impacts, (2) occur with an emphasis on sustainability, and (3) benefit the United States while taking into account concerns of the affected states and communities. One of several steps Congress directed the Secretary of the Interior (the "Secretary") to undertake that is directly related to the development of a commercial leasing program for oil shale and tar sands is the completion of a programmatic environmental impact statement (PEIS) to analyze the impacts of commercial development of oil shale and tar sands resources on public lands, with an emphasis on the most geologically prospective lands in Colorado, Utah, and Wyoming. The PEIS will evaluate potential impacts associated with oil shale and tar sands resource development on these lands.

This Class I cultural resources study in support of the Oil Shale and Tar Sands Resource Management Plan Amendments to Address Land Use Allocations in Colorado, Utah, and Wyoming and Programmatic Environmental Impact Statement (BLM 2007) is an attempt to synthesize archaeological data covering the most geologically prospective lands for oil shale and tar sands in Colorado, Utah, and Wyoming. This report is based solely on geographic information system (GIS) data concerning cultural resource surveys and sites held by the Colorado, Utah, and Wyoming State Historic Preservation Offices (SHPOs). These data include the information the BLM has provided to the SHPOs. The primary purpose of the cultural resources overview is to provide information on the affected environment for the PEIS. Furthermore, this report provides recommendations to support planning decisions and the management of cultural resources that could be impacted by future oil shale and tar sands resource development. Separate overviews are also being produced that describe the ethnohistoric context and the paleontological resources present in these regions (see Bengston 2007 and Murphey and Daitch 2007, respectively).

The data discussed in this study are organized by basin. The Piceance Basin in Colorado is presented first, after a brief introduction to BLM's program for managing cultural resources and the general types of data and analyses presented in this report. The Piceance Basin 
discussion is followed by summaries of the Uinta Basin and the Special Tar Sand Areas in Utah, and the Green River and Washakie Basins in Wyoming. Each area is discussed in terms of its environmental setting; prehistoric and historic context; previous overviews, surveys, and modeling efforts; known sites that have been recorded, as well as tested or excavated; and data deficiencies that set the stage for formulating research questions and recommendations for future cultural resource planning and management activities. The number of sites and surveys in the Oil Shale and Tar Sands PEIS study area is large given the vast extent of mineral development that has taken place in these areas; therefore, only a sampling of documents is discussed in this report. The programmatic nature of the oil shale and tar sands resources leasing program dictates that site-specific studies be conducted for specific lease parcels prior to the approval of development plans. This document discusses the status of decades of previous archaeological work, summarizes the lingering questions as presented by area scholars, and provides recommendations for future cultural resource management activities as they relate to oil shale and tar sands resource development.

The sensitivity maps were developed as part of this Class I overview. They are included in Appendix D. A discussion of the methods used to develop the maps is included in the appendix.

\subsection{STUDY AREA}

The study area for the oil shale resources includes the most geologically prospective resources of the Green River Formation located in the Green River, Piceance, Uinta, and Washakie Basins. The BLM has identified the most geologically prospective areas for oil shale development on the basis of the grade and thickness of the deposits. For the purposes of the PEIS, the most geologically prospective oil shale resources in Colorado and Utah are those deposits that yield $25 \mathrm{gal} /$ ton or more hydrocarbons (503,342 acres and 840,572 acres, respectively) and are $25 \mathrm{ft}$ thick or greater; in Wyoming, the most geologically prospective oil shale resources are those deposits that yield $15 \mathrm{gal} /$ ton or more hydrocarbons and are $15 \mathrm{ft}$ thick or greater (1,895,061 acres in the Green River Basin and 299,422 acres in Washakie Basin). Figure 1-1 shows the four oil shale basins that were mapped on the basis of the extent of the Green River Formation and the most geologically prospective oil shale resources within those basins.

For the tar sands resources, the study area includes those locations designated as Special Tar Sand Areas (STSAs) in the Utah Combined Hydrocarbon Leasing EIS (BLM 1984). Eleven STSAs were identified across different sedimentary provinces in Utah (Figure 1-2): Argyle Canyon-Willow Creek (hereafter referred to as Argyle Canyon), Asphalt Ridge-Whiterocks and Vicinity (hereafter referred to as Asphalt Ridge), Circle Cliffs East and West Flanks (hereafter referred to as Circle Cliffs), Hill Creek, Pariette, P.R. Spring, Raven Ridge-Rim Rock and Vicinity (hereafter referred to as Raven Ridge), San Rafael Swell, Sunnyside and Vicinity (hereafter referred to as Sunnyside), Tar Sand Triangle, and White Canyon. 


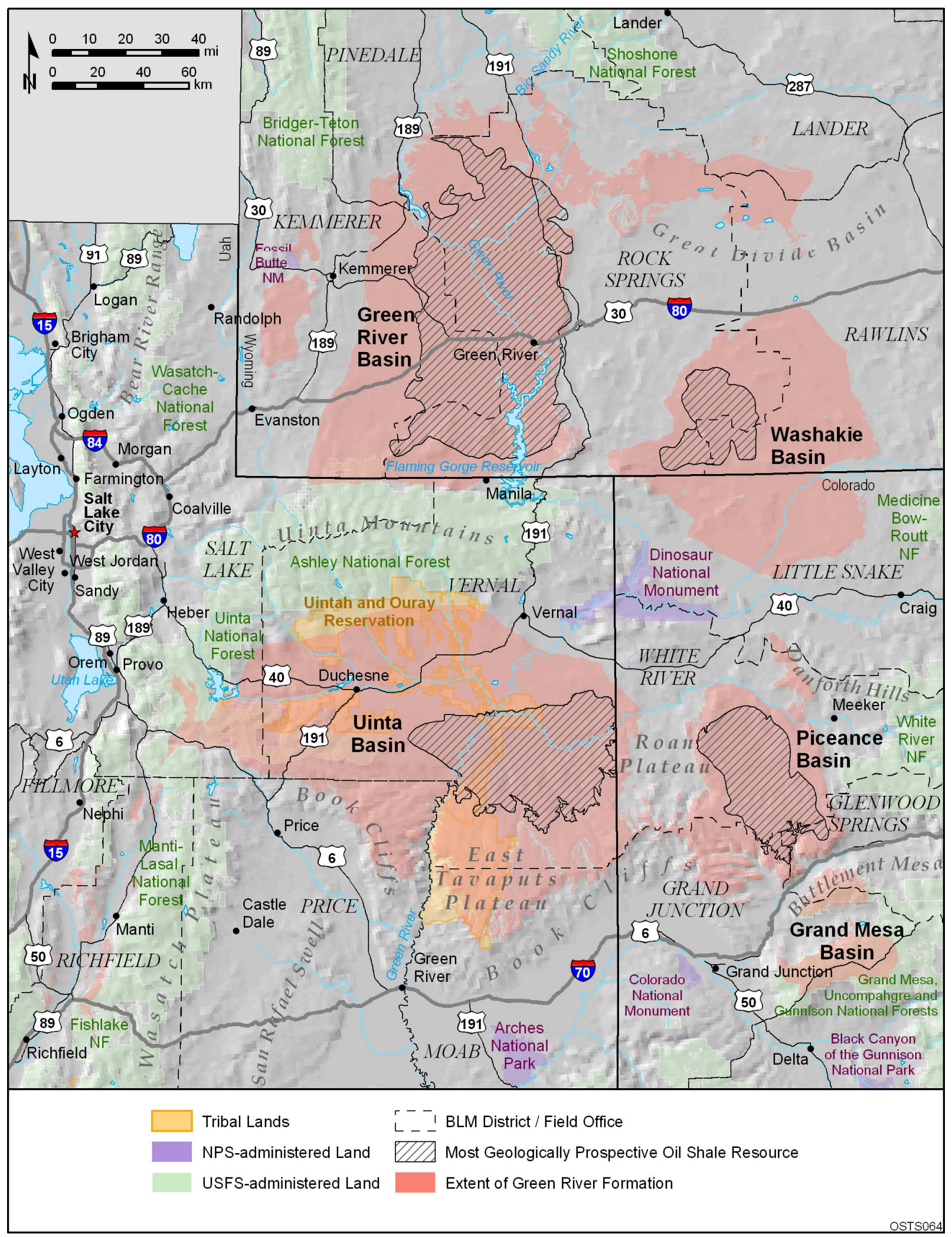

FIGURE 1-1 Map of the Most Geologically Prospective Oil Shale Resources within the Green River Formation Basins in Colorado, Utah, and Wyoming 


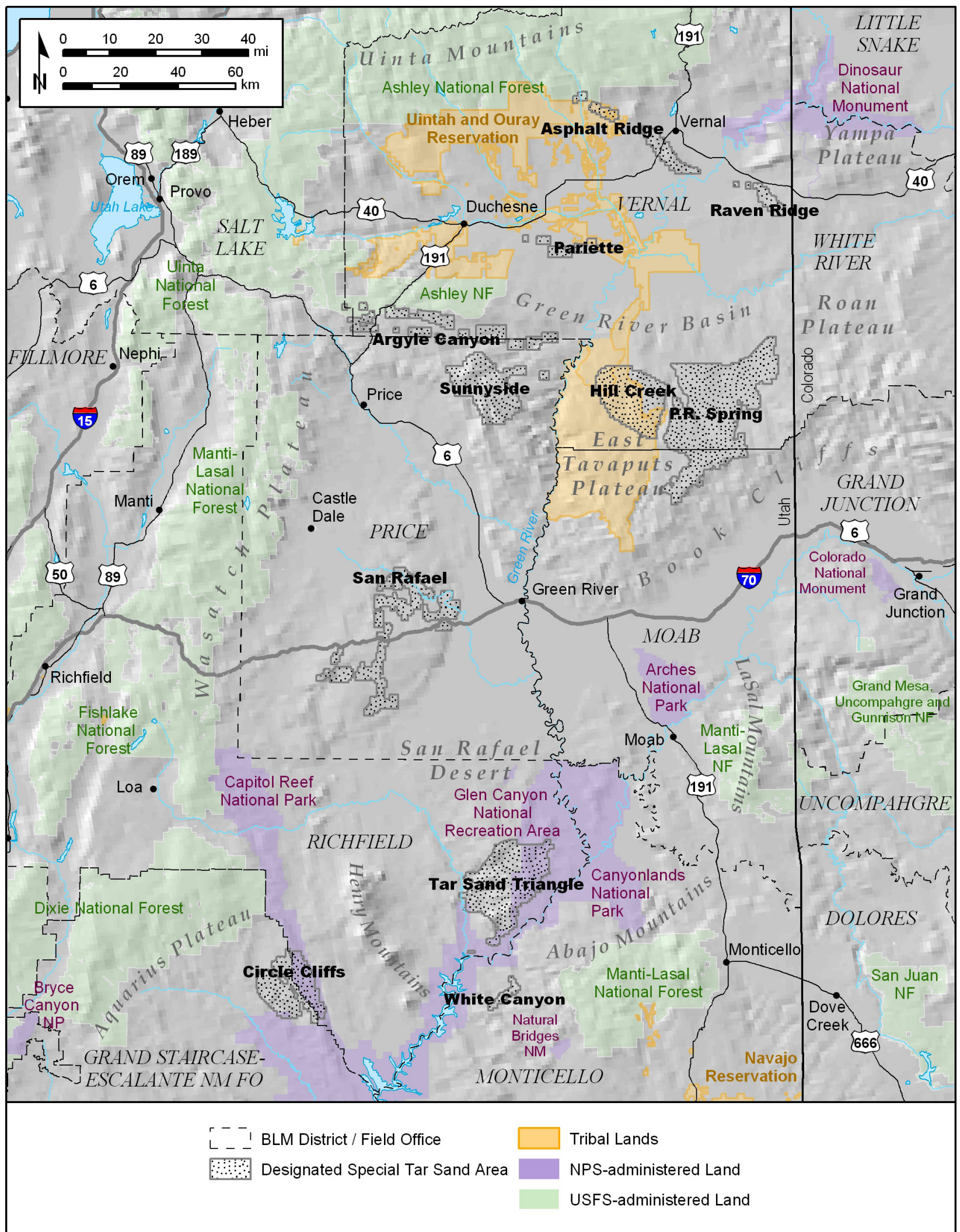

\section{FIGURE 1-2 Special Tar Sand Areas in Utah}




\subsection{COLLECTION AND ANALYSIS OF DATA}

The collection of data for this report focused on the information available at the Colorado, Utah, and Wyoming SHPOs, as well as readily available published reports, books, and overviews describing the cultural resources present in the oil shale and tar sands areas. The BLM did not provide any data for the report. Each SHPO provided GIS data for the areas of interest, including attribute data regarding surveys and sites, to the extent that they were available. These data were used to help identify key sources of information to pull from the files for review during visits to the SHPOs. Additional conversations with staff in these offices, the BLM, and other professionals supplemented the data collection beyond the initial selection of key sources identified by using the GIS data. By describing the extent of data available at the SHPOs and in published literature, this report should facilitate and help focus discussions with BLM archaeologists in the 3 state offices and 12 associated field offices regarding areas of possible oil shale and tar sands development.

The following subsections further describe the data examined and analyzed in this report in the context of BLM's responsibilities for managing cultural resources.

\subsubsection{BLM and the Management of Cultural Resources}

The BLM procedures for managing cultural resources are identified in Manual Series 8100. The procedures are designed to ensure compliance with the National Historic Preservation Act (NHPA) and other cultural resource authorities. The BLM, the National Conference of SHPOs, and the Advisory Council on Historic Preservation also entered into a Programmatic Agreement (PA) in 1997 to further facilitate the management of cultural resources under BLM's jurisdiction. A requirement of the PA is that BLM State offices develop state-specific agreements with the appropriate SHPO. Colorado and Wyoming have completed state protocols between the respective BLM state directors and the SHPOs. Utah also operates under a state protocol, but the $75 \%$ of the Vernal Field Office that is within the external boundaries of the Uintah Ute Indian Reservation are tribal lands under the NHPA. These lands are not covered by the BLM national PA or Utah protocol. The BLM follows the standard Title 36, Part 800, of the Code of Federal Regulations (36 CFR Part 800) process to meet its NHPA Section 106 responsibilities on tribal lands.

\subsubsection{Data (Reports and GIS)}

Electronic data were received in 2006 from each of the three SHPOs on the basis of GIS shape files sent to their offices delineating the oil shale and tar sands areas of interest. Attribute data were attached to the GIS data that describe surveys and sites, to the extent that these attribute entries had been populated. Each state has a unique system, and the data fields vary among them. Common information regarding survey reports (document identification and name of survey or project, year of survey, and investigator) is captured in survey tables for each basin. In some cases, additional information is available and included; however, this information is not consistent for each state. The site descriptive data are also largely incomplete except for 
locational data; any information available regarding site type and eligibility is included in site tables for each basin.

Because of the high number of surveys conducted in the large geographic areas constituting the most geologically prospective oil shale and tar sands areas, a sample of reports to review was chosen from each state. The GIS data were used to determine the reports that covered the largest portions of the study area. An attempt was made to choose a sufficient number of reports to widely cover each basin. The sample of reports does not include many of the smaller surveys in which no sites were found, because the results could be gleaned from the attribute data without reviewing the reports. Once an initial list of reports to review was developed, visits were made to each of the SHPOs in 2006 to review these reports. Additional overviews and more recent reports that may not have been entered into the GIS yet were requested in each office. Not all reports address areas that fall directly within the study area, but they offer a good synthesis or present new information pertinent to the study area. Information on excavated sites was collected, but most of the data collection focused on inventory. Site-specific issues must be dealt with at a more local level than the programmatic nature of this project will allow.

\subsubsection{Analysis}

The analysis conducted for this Class I cultural resource overview was simply a synthesis of large amounts of data collected for each of the prospective development areas for oil shale and tar sands. More detailed analyses of survey coverage and site types and site eligibility are included in the PEIS (described in Section 1.1) to differentiate between alternatives with different spatial configurations. This overview is limited to summarizing the total numbers of sites and surveys in the oil shale and tar sands areas. During the review of individual reports, survey issues and research questions were noted and have been included in this report. Recommendations based on these issues and questions have also been developed. The development of BLM use categories for the sites recorded in the project area based on these data is not possible at this scale.

\subsubsection{Constraints and Limitations}

As described above, each state has its own unique system for recording and presenting site and survey data. Fortunately, each has adopted a GIS framework and is fairly diligent in getting survey and site location information entered into its system. As can be expected, there is a backlog of data waiting to be entered. The presentation of data in this overview is limited to the BLM data that were entered into each SHPO's GIS at the time of the request. In some cases, where more recent information was known to exist that was relevant to the study area but was not in the database, those data were used. For example, several surveys were conducted in 2006 in support of BLM's research, development and demonstration (RD\&D) oil shale program. These reports had not yet been entered into the system. Copies of these reports were reviewed and are summarized herein. However, the data from these reports do not appear in the appendices of this document. 
Constraints and limitations in the use of the state data vary. The following describes some of the state-specific issues that were encountered during the preparation of this overview.

\subsubsection{Colorado}

Before the available data for Colorado could be accessed, some initial processing was required. Much of the site information was provided in an ascii text file format. The information provided in ascii format was not initially incorporated, which resulted in a vastly underrepresented site count, this led to some early confusion and misinterpretations of the data. Some instruction from the Colorado SHPO is necessary to work with its data. Beyond that issue, the data contain a considerable amount of information that is useful for understanding the types of cultural resources found in Colorado. The number of total acres surveyed was available for each survey report recorded. The data also summarized the total number of sites and isolated finds recorded for each survey. One limitation encountered with the Colorado GIS data was an inability to determine which sites have received additional examination and where that information can be found.

\subsubsection{Utah}

The GIS contains a large amount of data recorded for Utah. Much of the data were incorporated from the Intermountain Antiquities Computer System (IMACS) field forms used in Utah and follow the codes developed for that system. (A description of the IMACS is available at http://www.anthro.utah.edu/imacs.html.) The coding structure, versus text fields, makes the database somewhat cumbersome. There is also a great deal of duplication of fields as a result of incorporating IMACS information into the GIS database. However, much of the needed site data were included. One unique feature of the Utah data was the description of the site condition. Although this is not a topic discussed in this overview, it is something that the BLM should consider as an important field for addressing protection issues and overall status of the condition of sites within its areas.

\subsubsection{Wyoming}

The GIS data from the Wyoming Cultural Records Office (WYCRO) was the most complete and up to date. The most difficult issues for analysis purposes were the duplication of records (particularly with differing eligibility conclusions) and the inability to sort out acreages associated with specific survey areas. Several limitations of the WYCRO database are described in the Cultural Resources Class I Regional Overview for the Kemmerer Planning Area (BLM 2004b). These limitations are summarized here to the extent that they are pertinent to this overview; overall, however, the WYCRO database provided the most important types of information needed to complete this report. Information on the number of acres surveyed is only presented for Class III intensive surveys conducted in blocks; linear surveys do not include acreages. The data entry is not standardized and results in various terms being used to describe similar actions. This is primarily the result of having numerous people entering the information 
over time. The final limitations concern the type of data provided for each site. No information is provided on whether excavations have taken place at the site, and no environmental data are provided such as elevation, type of landform, or type of vegetation present at the site. 


\section{PICEANCE BASIN, COLORADO}

\subsection{ENVIRONMENTAL SETTING}

\subsubsection{Physiography}

The Piceance Basin is located mainly in the Colorado Plateau physiographic province. The overall basin is more than $100 \mathrm{mi}$ long and $60 \mathrm{mi}$ wide, with an area more than 7,000 $\mathrm{mi}^{2}$ (see Extent of Green River Formation labeled Piceance Basin in Figure 1-1). The Piceance Basin is simultaneously a structural, depositional, and drainage basin. The structural basin is downwarped and surrounded by uplifts resulting from the Laramide Orogeny. This tectonic activity created a depositional basin that filled with sediments from the surrounding uplands, mainly during the Tertiary period. The basin has a northern province and a southern province (Topper et al. 2003) that are separated approximately by the Colorado River and Interstate 70. Oil shale is present in both provinces, although in the southern province the key oil shale zones are isolated and are not considered within the scope of the PEIS.

\subsubsection{Geology, Soils, and Hydrology}

Within the Piceance Basin, the upper bedrock stratigraphy consists of a series of basin-fill sediments from the Tertiary period (Topper et al. 2003). The uppermost unit is the Uinta Formation, which consists of up to 1,400 ft of Eocene-age sandstone, siltstone, and marlstone. Below the Uinta Formation is the Eocene Green River Formation, which can be up to 5,000 ft thick and includes four members: Parachute Creek (keragenous dolomitic marlstone and shale), Anvil Points (shale, sandstone, and marlstone), Garden Gulch (claystone, siltstone, clay-rich oil shale, and marlstone), and Douglas Creek (siltstone, shale, and sandstone). The EocenePaleocene Wasatch Formation underlies the Green River Formation. The Wasatch is a shale and sandstone formation. Below the Wasatch is the Cretaceous Mesaverde Group (sandstone and shale), the Cretaceous Mancos Shale, and older sedimentary formations atop Precambrian rock. The main oil shale members of interest in the Piceance Basin are the Parachute Creek and Garden Gulch members. Quaternary alluvium of varying thickness is present in the significant drainages of the basin.

In addition to oil shale, the Piceance Basin contains the sodium minerals halite, dawsonite, and nahcolite, which are intermingled with the oil shale. Nahcolite is sodium bicarbonate, and it occurs in the Parachute Creek Member. Dawsonite is dihydroxy sodium aluminum carbonate and is found in the lower portion of the northern province of the Piceance Basin. Interbedded halite and oil shale are found in a sequence in the northern province of the Piceance Basin. Recoverable amounts of these minerals are estimated by the BLM (1983) for several individual tracts of land within the basin. Oil, natural gas, and coal are also present in the Piceance Basin although the coal is too deep to be commercially viable (DOI 1973). Natural gas has been produced in the northeastern part of the basin, with the most productive zone at the base 
of the Green River Formation. An oil field is near the northwestern part of the basin, and coal deeply underlies essentially the entire basin (DOI 1973).

Soils vary in the Piceance Basin in their thickness and character (DOI 1973). On upland areas, soils are generally rocky with shallow depth to bedrock. Slopes in these areas are typically 10 to $60 \%$. Eolian deposits (silt) may blanket the upland surface. Deep alluvial soils are found in drainageways and in valleys, with slopes less than $10 \%$. Locally, valleys may contain colluvium from the side slopes. Erosion occurs mainly along roads and trails and in stream valleys. Intermittent creeks show head cutting, bank cutting, and deep gullying. On upland ridges and cliffs, soil formation is minimal because of steep slopes and strong winds. Erosion is mainly by wind where overgrazing has exposed thin loamy soils. Gullying is possible in small drainageways, as is mass wasting of weathered soil and rock.

The Piceance Basin is part of the Upper Colorado River Basin. It is principally drained by the Colorado, Gunnison, North Fork Gunnison, and White Rivers. Water management responsibility is divided between several Colorado Water Divisions.

Snowmelt from upper elevations provides recharge for the Piceance Basin. The most productive aquifers are found within unconsolidated alluvial deposits formed mainly along stream courses. The sand and gravel deposits are generally narrow and thin. The basin contains two bedrock aquifers within and above oil shale reserves. The upper and lower Piceance Basin aquifers are within lower Tertiary Eocene material. They are separated by the Mahogany Zone, which is composed of oil shale that slows water movement between zones. Coal and methane are found in Cretaceous material beneath the aquifers. The upper bedrock system consists of several permeable zones. The Eocene Uinta Formation contains silty sandstone and siltstone subaquifers. The upper part of the Parachute Creek Member of the eocene Green River Formation contains fractured dolomite marlstone subaquifers. Primary porosity is enhanced by natural fracturing. The subaquifers and intervening layers of low-permeability material compose the 700-ft-thick upper aquifer system. Fractured dolomitic marlstone of part of the lower Parachute Creek Member of the Green River Formation composes a lower aquifer about $900 \mathrm{ft}$ thick. It is semiconfined by the Mahogany Zone above and a resistivity zone, and the Garden Gulch Member of the Green River Formation below. Natural fracturing and solution enlargement have increased permeability. Potable water within the basin is obtained from shallow wells because of the mineral content (notably sodium bicarbonate and salt) of groundwater beneath about $200 \mathrm{ft}$. Deeper wells are used for other purposes.

\subsubsection{Climate, Flora, and Fauna}

The Piceance Basin lies within the Colorado Plateau ecoregion (Chapman et al. 2006). The Colorado Plateau ecoregion is characterized by a rugged tableland of mesas, plateaus, mountains, and canyons, often with abrupt changes in local relief. Within this ecoregion, the northern portion of the basin, primarily located in Rio Blanco County, is included in the Semiarid Benchlands and Canyonlands subregion. Broad benches and mesas in alternating areas of high and low relief support grassland, shrub, and woodland vegetation types. Escarpments, hillslopes, cuestas, alluvial fans, and narrow canyons, are also characteristic of this region. A few 
isolated peaks also occur. Elevations range from 5,400 to 9,200 ft, with local relief up to 1,000 ft. Deep soils of fine sand support sagebrush steppe with warm season grasses (i.e., galleta grass and blue grama) and shrubs (primarily black sagebrush, winterfat, mormon tea, fourwing saltbush, and shadscale). Shallow stony soils support piñon-juniper woodlands of two-needle piñon pine and Utah juniper. Greasewood shrub communities occur on drainage bottoms with poorly drained soils from 5,200 to 6,600 ft in elevation. Many drainages in the area, including the White River and Yellow Creek drainages, support extensive greasewood stands. Scattered woodlands of gambel oak occur at the higher elevations. The average annual precipitation is about 10 to $18 \mathrm{in.}$ in lower areas and 20 to $25 \mathrm{in}$. at the highest elevations. This subregion has a moderate to long growing season with 60 to 120 mean annual frost-free days. Vegetation is generally not as sparse as in the drier ecoregions.

The southern portion of the Piceance Basin, in Garfield County, lies within the Escarpments subregion. Extensive cliff-bench complexes characterize this region and ascend to the forested mountain rim. High, deeply dissected cliffs, escarpments, and mesa tops are typical. Elevations range from 6,000 to 9,000 ft, with local relief up to 3,000 ft. The Book Cliffs and Roan Cliffs are major local scarp slopes, and the region is prone to landslides. The average annual precipitation is 15 to 25 in., with up to $32 \mathrm{in.} \mathrm{at} \mathrm{higher} \mathrm{elevations.} \mathrm{This} \mathrm{subregion} \mathrm{has} \mathrm{a}$ short to moderate growing season with 60 to 90 mean annual frost-free days. Lower drier sites in the region support desert and semidesert grassland or shrubland, while steep, north-facing slopes at higher elevations support Douglas fir forest with mountain mahogany and aspen. The predominant vegetation type of shallow soils on escarpments and benches is piñon-juniper woodland. Arid grassland terraces support galleta, cheatgrass, saline wildrye, and broom snakeweed (BLM 1987). A number of shrubland communities occur. Saltbush communities on benches include shadscale, galleta, broom snakeweed, and cheatgrass. Dominant species on eroded land include Nuttall's saltbush, shadscale, and saline wildrye. Greasewood communities on uplands include black greasewood, cheatgrass, and burr buttercup. Mountain mahogany and aspen woodlands are additional vegetation types. Quaking aspen woodland occurs above 7,000 ft on soils with relatively high moisture, such as north and northeast facing slopes in the southwestern portion of the Piceance Basin.

Moist meadow wetlands occur at the headwaters of drainages on the Roan Plateau (BLM 2006). These wetlands are dominated by herbaceous species. Riparian shrub communities occur along the bottoms of major drainages. These communities include willow, elderberry, gooseberry, and riparian grasses. Lower reaches of the main drainages on the plateau support a narrow zone of coniferous woodland, composed primarily of blue spruce and Engelmann Spruce with interspersed shrubs. A number of streams on the plateau support deciduous woodlands along their margins. These woodlands are composed of narrowleaf cottonwood, boxelder, and shrubs. Hanging gardens occur along canyon walls, predominantly north-facing walls where Green River shale beds are exposed, where seeps provide consistent moisture throughout the year.

In the Grand Junction Field Office, nonwooded riparian areas support saltcedar, saltgrass, rush, and bulrush; species of wooded riparian areas include cottonwood, boxelder, skunkbrush, and willow (BLM 1987). Riparian and wetland habitats in the Glenwood Springs Resource Area 
include grassland with sedge and rush species (BLM 1988). Riparian habitats in this resource area also support cottonwood and willow, along with associated grasses and forbs.

Big game species within the study area include elk, mule deer, pronghorn, bighorn sheep, moose, American black bear, and mountain lion. Presently, the elk and mule deer are generally the most abundant, widely distributed, and sought-after big game in the region (BLM 2004c). A number of the big game species make migrations when seasonal changes reduce food availability, when movement becomes difficult (e.g., because of snowpack), or where local conditions are not suitable for calving or fawning. Established migration corridors for these species provide an important transition range between seasonal ranges and provide food for the animals during migration (Feeney et al. 2004). Water availability is a major factor affecting the distribution of big game species (BLM 2004a).

Small mammals include small game, furbearers, and nongame species. Small game species that commonly occur within the oil shale study area include black-tailed jackrabbit, desert cottontail, mountain cottontail, snowshoe hare, white-tailed jackrabbit, and yellow-bellied marmot. Common furbearers include American badger, American beaver, American marten, bobcat, common muskrat, coyote, red fox, striped skunk, and weasels. Nongame species include bats, shrews, mice, voles, chipmunks, and other rodent species.

Upland gamebirds that are native to the study area include blue grouse, ruffed grouse, greater sage-grouse, and mourning dove; introduced species include ring-necked pheasant, chukar, gray partridge, and wild turkey. All of the upland game bird species within the study area are year-round residents.

\subsection{REGIONAL PREHISTORY}

There is archaeological and ethnographic evidence to suggest that the Piceance Basin was inhabited and visited on a regular basis by human populations prior to Euroamerican settlement of the region. The post-Pleistocene climate of the area is not expected to have differed too greatly from that of the present (Hurlbett 1976). Abundant native faunal and floral resources were available to human populations as part of a seasonal round of subsistence. Hunting and gathering could be practiced year-round. Permanent seasonal water sources within the area attracted numerous animal species, including mule deer. Today, the Piceance Basin supports the largest migratory herd of mule deer in the United States (Conner et al. 2005a,b). It is not expected that the majority of prehistoric populations practiced horticulture in the Piceance Basin per se, because of the relatively short growing season and inadequate soil conditions. However, horticultural sites are found very near to the basin, such as in the Douglas Creek area to the west, and Dinosaur National Monument to the northwest (Grady 1980; Hurlbett 1976; Reed and Metcalf 1999). Thus, the basin appears to have contributed significantly to the plant and animal resource base of the prehistoric populations of northwestern Colorado.

Several historic contexts have been developed for northwestern Colorado that can be applied to the Piceance Basin. These contexts examine the region's recent (historic) and distant (precontact or prehistoric) past and are based on decades of archaeological and historical 
research. They are designed to generally describe and interpret the cultural history of the region, and to give basic insight into the prevailing theories pertaining to prehistoric and historic communities existing in specific locations and at discreet points of time.

The cultural histories that focus on prehistoric Native American populations in northwestern Colorado are placed into a chronological framework divided into four major time periods, or eras, as defined by Reed and Metcalf (1999). These eras include the Paleoindian era (11,400 to 5,500 B.C.), the Archaic era (6,400 to 400 B.C.), the Formative era (400 B.C. to A.D. 1300), and the Protohistoric era (A.D. 1300 to 1881). These eras are divided into various traditions, described in the following paragraphs. The Archaic period is commonly further subdivided into the Early, Middle, and Late periods, although these distinctions are not used by Reed and Metcalf. The discussions presented here are intended to illustrate broad patterns characteristic of each of these phases of cultural development represented in the study area.

\subsubsection{Paleoindian Era (11,000 to 6,500 B.C.)}

The Paleoindian era marks the earliest known occupation of North America by Native Americans. The Paleoindian refers to the transitional period of time at the close of the Pleistocene and into the early Holocene, when Native American populations consisted of small, mobile communities with a strong focus on hunting as the primary subsistence strategy. Evidence for Paleoindian occupation occurs throughout the continent and does not demonstrate much local variation. The archaeological data suggest that Paleoindian groups were highly mobile, generalized hunter-gatherers moving on a seasonal basis to exploit available natural resources. Despite their specific location on the North American landscape, it is more likely that the gathering of plant resources played a more significant role in daily subsistence than originally thought. Archaeological evidence from Paleoindian sites throughout western North America indicates that these communities initially hunted a limited number of large animals (megafauna) such as mammoth and mastodon in a variety of environmental settings. As the Pleistocene ended and the Holocene began, the megafauna became extinct and hunting strategies shifted to other animal resources. In many areas, the hunting focus shifted to the largest remaining species, the bison. In addition to bison hunting, the gathering of wild plant foods and the hunting of smaller animals became equally as important.

The Paleoindian era in northwestern Colorado is divided into four traditions defined by the stone tool assemblages found throughout the region. The well-known Clovis tradition $(11,400$ to 10,500 B.C.) is characterized by large lanceolate, fluted projectile points. The fact that the bases of projectile points created by the early Paleoindians are often fluted differentiates them from the later, unfluted Paleoindian tools and suggests use on big game. Clovis tradition projectile points are represented in the project area as isolated finds. Site 5RB2263, located south of the town of Rangely in Rio Blanco County, contains a Clovis point (Grady 1984).

Goshen tradition (11,000 to 10,700 B.C.) projectile points are also found in northwestern Colorado and appear contemporaneous with the Clovis tradition. Goshen diagnostic artifacts are large, unfluted lanceolate points that have also been found in association with big game (Reed and Metcalf 1999). The Upper Twin Mountain site (5GA1513), located north of Kremmling in 
Middle Park, Grand County, yielded a Goshen tradition projectile point in association with a bison bone bed. Radiocarbon dates from the bison bone indicate 9,600 B.C., which is later than the expected range of Goshen sites. Frison and Kornfeld's (1995) work at this site suggests yearround occupation and less annual mobility in Middle Park than at other early Paleoindian sites. Overall, early Paleoindian sites appear clustered along major rivers and creeks in lower elevations. The Folsom tradition (10,800 to 9,500 B.C.) is also characterized by fluted lanceolate projectile points found in association with bison kill sites. Folsom sites are not common in northwestern Colorado. The majority of such sites in the region occur in Middle Park, suggesting that this area was optimal to support Paleoindian populations (Reed and Metcalf 1999:57).

Following the Folsom tradition, northwestern Colorado appears to present a blurry boundary area that contains a mix of both the Plano tradition of the Great Plains and the FoothillMountain complex. While Plano tradition sites focus on bison hunting, Foothill-Mountain sites reveal exploitation of deer, bighorn sheep, and pronghorn antelope in addition to increased exploitation of floral resources. Evidence for these traditions, as with all PaleoIndian sites, is sparse; however, research by Pitblado (1994) indicates that the Foothill-Mountain complex follows the Folsom tradition in southwestern Colorado. Reed and Metcalf (1999) suggest that based on the similarity of the environment, the Foothill-Mountain tradition also may be present in northwestern Colorado. Considering the available animal and plant resources, especially mule deer, in the region, this is a likely assumption. Pitblado's study suggests that Foothill-Mountain populations may be more closely affiliated with contemporaneous Great Basin populations to the west, which show more regional variation at this stage and are often linked to early Archaic populations.

\subsubsection{Archaic Era (6,350 to 350 B.C.)}

The Archaic era in North American prehistory represents a shift from a highly mobile hunting lifestyle to a greater reliance on gathering wild plant foods and hunting smaller game. The subsistence shift is represented in the stone tool assemblages. Shifts in diet and settlement patterns define the transition to the Archaic. During this period, it seems that native people were adapting to environmental changes by using more diverse plant and animal resources, and creating and using a broader range of tools, including new projectile point forms and ground and pecked stone tools, as well as slab milling stones, small manos, digging sticks, atlatls, netting, baskets, and awls (Jennings 1978, 1989). The projectile points found associated with Archaic peoples are stemmed or notched varieties as opposed to the large, lanceolate points of the Paleoindian era. Although some research suggests that community size increased during the Archaic period, some archaeological evidence counters that assumption, suggesting that community sizes remained small, and that day-to-day activities took place at a series of seasonal camps. Archaic people began developing regional differences within their material culture during this period, and this, too is represented in the numerous projectile point styles found throughout the continent.

In western North America and in particular in northwestern Colorado, however, there is less evidence that the Archaic was a "stage" of cultural development between the Paleoindian and later cultural developments as it is often described in eastern North America. The Archaic 
lifestyle in many ways continued from the late Paleoindian period until the time of contact with Euoramerican settlers. Although there are distinct differences found in Archaic sites and in Formative era sites, the basic Archaic lifeways continued throughout the Formative era (Reed and Metcalf 1999).

Much like during the Paleoindian era, human populations were attracted to the climate of the Piceance Basin during the Archaic era for several reasons, including the abundant plant and animal resources found along major rivers and creeks that could be exploited on a year-round basis, as well as access to higher elevations in the summer where cooler temperatures prevail, and warmer climatic conditions in the lower elevations in winter. A more recent research focus has been on the evidence of structures at Archaic sites throughout the region. Evidence of structures is found at sites in Middle Park and other sites in the vicinity (Reed and Metcalf 1999).

Research at Deluge Shelter, located on the Colorado-Utah border, still contributes significantly to our understanding of Archaic lifeways in northwestern Colorado. Jennings (1978) notes that the mule deer was most abundant in the faunal assemblages of all the Archaic levels at Deluge Shelter. Cave deposits also contained a large amount of seeds and other plant remains, which indicates a heavy reliance on these resources for food and other nonedible items (baskets, mats, and net fragments).

The Archaic is traditionally divided into three phases: Early (7,500 to 4,000 B.C.), Middle (4,000 to 2,000 B, C.), and Late (2,000 to 650 B.C.) (Aikens and Madsen 1986), although the dating varies for these periods. Reed and Metcalf (1999) do not distinguish among these periods, but rather discuss the Archaic as a long, stable tradition of prehistoric life in northwestern Colorado, punctuated by some significant shifts in climatic conditions that undoubtedly caused shifts in Archaic subsistence strategies and settlement patterns. These shifts are defined by Reed and Metcalf as a four-part series, including the Pioneer (6,350 to 4,450 B.C.), Settled (4,450 to 2,450 B.C.), Transitional (2,450 to 950 B.C.), and Terminal (950 to 350 B.C.) periods of the Archaic. Despite some theories that community size did not increase, the Archaic era overall exhibited increased populations, increased sedentism, diversity in subsistence strategies, and increased variety in material culture.

\subsubsection{Pioneer Period}

The Pioneer period (6,350 to 4,450 B.C.) is described as the period of shift from highly mobile Paleoindian adaptations to the more established seasonal settlement systems. Like the Early Archaic period, evidence from sites in the region indicates that the sites were located near marshy riparian environments along lakes and rivers (Aikens 1983 and Madsen 1986). Resources such as waterfowl, shorebirds, and small mammals were exploited. However, in northwestern Colorado, animals such as bison, deer, antelope, and bighorn sheep continued to be frequently exploited (Aikens 1983). 


\subsubsection{Settled Period}

The Settled period (4,450 to 2,450 B.C.) shows even more increased locally oriented occupations where central-place foraging strategy could be practiced year-round. According to Metcalf and Reed (1999), the use of pit and basin structures became established during this time period.

\subsubsection{Transitional Period}

The Transitional period $(2,450$ to 950 B.C.) is characterized by increasing variability in material culture and increased seasonality in the use of the higher elevations. Generally corresponding to the time frame of the traditional Middle Archaic period (4,000 to 2,000 B.C.), the Transitional period coincides with the Altithermal climatic shift, which caused increased aridity in the environment of the lowland areas and a shrinking or disappearance of many marshland and lake margin environments. This climatic shift is a possible indication of why there were changes in settlement patterns and in the subsistence strategy of the Archaic groups during this period. The populations appear to have settled in the higher elevations, where new resources could be exploited. In northwestern Colorado, these resources were already being utilized by the same Archaic groups; thus, the shift to settlement in higher elevations merely indicates a heavier reliance of these same resources, such as deer, elk, and bighorn sheep. The diagnostic projectile point types from the Early Archaic continue to be the dominant types in the Middle Archaic of the Eastern Great Basin, with the addition of some lanceolate types (Jennings 1986).

\subsubsection{Terminal Period}

The Terminal period (950 to 350 B.C.) is defined by a shift to what is more classically defined during the early Formative era, where the early experimentation with bow and arrow use, corn cultivation, and an increasing shift toward processing of seeds and other lower rate-ofreturn foods appears (Reed and Metcalf 1999). The Late Archaic includes this period, when climatic changes produced a wetter and cooler environment. The archaeological record shows that the upland zones continued to be occupied because of the absence of the marshland/lake margin ecosystem as the result of flooding (Aikens 1983).

\subsubsection{Formative Era (400 B.C. to A.D. 1300)}

Traditionally, the beginning of the Formative era in the western and southwestern United States signifies the shift from the seasonal hunter-gatherer subsistence strategy toward that of horticulture. Early farming practices focused on the domestication of maize and to a lesser degree beans and squash. However, hunting and gathering continued to play a major role in the economy, and in many respects the subsistence pattern was similar to that of the Archaic period (Grady 1984). In northwestern Colorado, the Formative era is represented by two distinct traditions, the Fremont and Aspen (Reed and Metcalf 1999). 


\subsubsection{Fremont Tradition}

The term "Fremont" refers to a widespread group of cultures located throughout northern and central Utah, with the eastern extent located in adjacent portions of western Colorado. Although vehemently debated, the "Fremont" culture is still used to describe the Formative cultures that developed in Utah and Colorado. The Fremont varies widely, but can be generally characterized by a change to a more sedentary lifestyle in villages and the adaptation to horticulture to supplement the existing foraging and hunting subsistence cycle (Marwitt 1986). In northwestern Colorado, however, the shift to increased sedentism (and increased use of structures) began in the Archaic and was not new to the Fremont time period. However, the development of horticulture is unique to the Fremont. The main cultigen was corn, with some evidence of beans and squash (Aikens 1983; Grady 1984; Jennings 1978; Marwitt 1986). The Fremont is also associated with the introduction of pottery and the appearance of unique rock art and modeled clay figurines (Marwitt 1986).

The Fremont sites in the Piceance Basin and vicinity would most closely relate to a Plains-influenced variance of Fremont known as the Uinta Fremont, named for the main locus of the variant in the Uinta Basin in Utah, which also extends north into southwestern Wyoming and east into northwestern Colorado. The Uinta Fremont is a distinctive local variant that appears to have developed out of the Terminal Archaic. The basin itself appears to have been used by Fremont groups largely for hunting and gathering purposes (Hurlbett 1976; Grady 1980).

Important characteristics of the Uinta variant include the presence of shallow pit-houses and free-standing structures, and the complete absence of Fremont clay figurines and the "Utah type" metate. Large, shouldered Fremont blades, triangular and ovoid blades, and corner and side-notched projectile points are also present (Marwitt 1986). It should be noted, however, that although horticulture was practiced, it does not appear to have superseded hunting and gathering practices in northwestern Colorado as the prominent subsistence strategy.

Fremont sites located in Moffat and Rio Blanco Counties include rock art sites, open and sheltered artifact scatters, and architectural sites. The majority of the architectural sites are granaries. According to Reed and Metcalf (1999), no confirmed Fremont pit-houses were found in the study area. However, the pottery styles found at these sites link them to the Uinta Fremont culture. Uinta Grey and Douglas Arch ceramic styles are present. Rosegate, Desert side-notched, Uinta side-notched, Cottonwood Triangular, and Elko corner-notched points are also found at the sites. The Texas Creek Overlook site (5RB2435), exhibiting both Uinta Grey sherds and Cottonwood Triangular points, is distinct in that it shows a very late Fremont presence in the region (A.D. 1414 to 1631). The Sky Aerie Promontory site (5RB104) revealed human remains associated with Uinta Fremont diagnostic artifacts.

With the exception of the late date of Fremont occupation at the Texas Creek Overlook site, the Fremont cultural traits seem to disappear from the area by A.D. 1300, although it is not known exactly what caused the abandonment of the Fremont lifestyle. Leach (1970) notes that the latest Fremont level at Deluge Shelter contained distinct faunal and floral evidence and different projectile point and grinding stone styles, which indicates a shift from horticulture back to one of foraging and hunting (Marwitt 1986). Spangler (1993) offers that the paucity of 
residential sites in the late Fremont occupation of the region also suggests a shift from horticultural practices back to entirely hunting and gathering. Nonetheless, the late occupation of the Fremont culture in this area is unique, and may suggest that the region was the last homeland of the Fremont peoples (Reed and Metcalf 1999).

\subsubsection{Aspen Tradition}

Contemporaneous with the Fremont culture in northwestern Colorado, the Aspen Tradition (400 B.C. to A.D. 1300) is assigned to nonhorticultural groups residing in the region during this time. One of the most marked changes that occurred during this period is the technological change to the use of the bow and arrow. Small, corner-notched points prevail prior to A.D. 1000, followed by the use of side-notched varieties. However, bow and arrow use also appears at Fremont sites at the same time. At Aspen tradition sites, there is little in the way of ceramics. The sherds are described as generic gray wares, which most ceramicists hesitate to assign as Fremont or Fremont-influenced (Reed and Metcalf 1999). Aside from the lack of evidence for horticulture and Fremont-style pottery, Aspen tradition sites do not appear much different from the Fremont sites. In addition, Reed and Metcalf indicate that the Aspen tradition and Fremont tradition are comingled in the study area. On the basis of this information, the data appear ambiguous as to which tradition the sites can be assigned.

\subsubsection{Protohistoric Era (A.D. 1300 to 1881)}

The commencement of the Protohistoric era is defined by what appears to be a gradual ending to the Fremont horticultural lifeways in northwestern Colorado and the adoption of a more mobile, hunter-gatherer life style. Two theories exist as to the origin of these huntergatherer groups. Early research suggested that a northeastern migration of Southern Numicspeaking groups, originating from southern California and northern Mexico, replaced the Fremont in the Eastern Great Basin (Lamb 1958). The Southern Numic speakers belonged to a branch of the Uto-Aztecan linguistic family. These groups were thought to have moved into the eastern portion of the Great Basin around A.D. 1200 and either replaced the Fremont populations or mixed with them, spreading rapidly throughout the area (Callaway et al. 1986). By A.D. 1300, these groups would have reached the Piceance Basin and other areas of northwestern Colorado and would have undoubtedly encountered Fremont (or Aspen tradition) groups remaining in the area. However, Grady (1980) postulates that there are no valid arguments to discount the theory that the Fremont groups simply abandoned horticulture when it became no longer economically feasible and reverted to a subsistence strategy based on the seasonal round of hunting and gathering. In either case, these Protohistoric hunter-gather groups were ancestral Ute, who resided in the vicinity until their removal to reservations in 1881 (Grady 1980; Reed and Metcalf 1999).

Archaeological evidence from Protohistoric sites in northwestern Colorado indicates that these groups had a subsistence regime much like that of the Archaic populations before them. They appeared to be highly mobile, exploited a variety of plant resources for food, clothing, and supplies; and they hunted small mammals and large herbivores, such as bison, mule deer, and 
antelope. The Desert Side-notched projectile point, used with the bow and arrow, and the production of distinct "flower pot" brown ware pottery (Uncompahgre Brown Ware) are the hallmarks of these groups. Structures found at Protohistoric sites are wikiups, or brush structures (Grady 1980; Reed and Metcalf 1999).

The Protohistoric Ute period can be subdivided into three cultural phases on the basis of a study of the Eastern Ute by Reed (1988). This chronology provides some understanding of the Ute in northwestern Colorado. Sites from the Chipeta phase (A.D. 1250 to 1400) contain no Euroamerican historic artifacts and appear to represent an Archaic lifestyle. Wikiups, Desert Side-notched points, and Cottonwood triangular points are common. The Canalla phase (A.D. 1400 to 1650) refers to the time period between the hunter-gatherer lifestyle of the Ute and the first contact with the Spanish. Sites contain lithic artifacts such as those found in the Chipeta phase, along with Uncompahgre Brown Ware ceramics. The Antero phase (A.D. 1650 to 1880) represents the shift to a lifestyle based on the introduction of the horse, which increased the Ute's contact with Euroamerican settlers in the region. Teepee rings appear in the archaeological and historical record, indicating that it was during this time period that the Ute adopted the teepee over the traditional wikiup structure (Metcalf et al. 1989). In 1881, the Ute were removed from northwestern Colorado to reservations located in Utah.

\subsection{REGIONAL ETHNOHISTORY}

The traditional territory of the Utes roughly included the western two-thirds of presentday Colorado and extended west through most of Utah and south into northernmost New Mexico. Utes practiced hunting and gathering subsistence economies until the introduction of the horse at the end of the seventeenth century. Some bands then adapted the bison-hunting Plains lifestyle. Dispersed family groups coalesced into large, but fluid, mobile bands that came to be dominated by war leaders. The Yamparika, Parianuche, and Taviwach bands probably occupied territories within the Colorado portion of the study area (Young 1997; Callaway et al. 1986).

\subsection{REGIONAL HISTORY}

\subsubsection{Early Explorations and Fur Trade}

The first European visitors to Colorado were the Spanish during the late 1600s, as they traveled out of Mexico seeking valuable minerals or land rich enough for agriculture. In 1695, Diego de Vargas visited the San Luis Valley in Colorado. In 1765, Juan de Rivera explored the San Juan area and reached the Black Canyon of the Gunnison. However, finding nothing of value, these early explorers returned home, ending Spanish exploration in Colorado until 1776. It was at this time that the first recorded European visitors arrived in northwestern Colorado. Fray Silvestre Velez de Escalante and Fray Francisco Atanasio Dominguez, two Franciscan friars, set out from Santa Fe north to Colorado for the Catholic Church, seeking a new route to travel to the 
California missions. This new route was necessary because of resistance from the Hopi Indians, who had blocked the main route through Arizona (Athearn 1982).

With seven others, the two friars began their journey north from New Mexico into Colorado. By August of that year, they had reached the confluence of the Gunnison and the Uncompahgre Rivers, where a group of "Yuta" Indians helped them to make the river crossing. Shortly thereafter, the party traveled north and became the first Europeans to cross the Grand Hogback, the Grand River, and Piceance Creek Basin. By September, the party had reached DeBeque, Colorado, and then proceeded north along Roan Creek to Douglas Creek, to the White River. While traveling in this area, they visited Painted Canyon, which they erroneously reported contained veins of gold in the canyon walls. The group reached Utah in September of 1776. They returned home via Utah and Arizona, as they did not find a route to California (Athearn 1982).

Following Mexican independence from Spain in 1821, Colorado was opened to the fur trade, which flourished from approximately 1824 to 1840. During this time, American fur traders trapped beaver for pelts in the Green, Yampa, and White Rivers to the north, the Eagle, Blue, and Colorado Rivers to the east, and the Colorado, Gunnison, Uncompahgre, Dolores, Animas, and San Juan Rivers to the south, of the Piceance Creek Basin. Fort Robidoux, built by Antoine Robidoux in 1828, was located near the present-day town of Delta, Colorado. Fort Robidoux was one of two important trading and supply posts in northwestern Colorado until its destruction by the Utes in 1844. The other trading post was Fort Davy Crockett, located in Brown's Park (Husband 1984). Robidoux ventured into North, Middle, and Brown's Park to trap, and eventually worked the White River as well. He and his party were the first to trap along the White River, and they are suspected of being the first American visitors to the Piceance Creek Basin (Athearn 1982).

The fur trade was successful in Colorado until the early 1840s, when it experienced a decline because of a drop in the beaver populations from overtrapping and the changing fashions in Europe from fur hats to those made of silk (Athearn 1982; Husband 1984). Although a few resilient fur traders continued to work in northwestern Colorado into the 1870s, most had moved out of the area permanently or had chosen other means of employment (Athearn 1982; Husband 1984).

Before, during, and after the heyday of the fur trade, American explorers ventured into the West in an effort to survey and investigate the land. After the Louisiana Purchase in 1803, vast areas of the country were opened up for exploration. This continued until 1876. Several of these explorers crossed the land in and around the Piceance Creek Basin on their journeys through northwestern Colorado. These explorers included Benjamin L.E. Bonneville in 1829 and 1832; the Thomas Jefferson Farnham party and the F.A. Wislizenus party in 1839; and E. Williard Smith in 1840. None of these explorers offered much information regarding their trips through northwestern Colorado, except that the area in around the Little Snake River was "quite dry and useless" (Athearn 1982).

John Charles Fremont led major U.S. Army expeditions into the West in an effort to map and survey for the U.S. Government. In 1844, he had explored Colorado, crossing the region near the Yampa Valley. Fremont led an expedition one year later into Colorado again, in 
preparation for war with Mexico. During this trip, Fremont and his men searched for routes to invade Mexico. They traveled from the Arkansas River to Tennessee Pass, where they crossed into the Grand River valley. From there they ventured north to the White River, then turned west and followed it to the Green River. Despite his efforts, Fremont's travel journals did not include much information pertaining to northwestern Colorado. The region was considered to be worthless until after 1859 when gold was discovered in Colorado (Athearn 1982).

The gold was found along Cherry Creek near Denver. Although the gold was not that plentiful, the entire state experienced a gold rush caused by the promotion of mining opportunities in the Eastern and Midwestern newspapers. With an influx of miners and opportunists arriving, the need for trail blazing and wagon road building became increasingly important. Edward L. Berthoud, a Swiss engineer, was the first to blaze a trail across northwestern Colorado following the White River to the Green River, and then on to Salt Lake City, Utah (Athearn 1982). However, it was not until John Wesley Powell set out to survey northwestern Colorado during the 1860s that the region became well known. In 1868, Powell and his party left Bridger, Wyoming, for the White River and then on to the Green River. Powell was the first to officially report on northwestern Colorado. He stated that little agriculture could be supported without large-scale irrigation; ranching could be supported (Athearn 1982). Powell's expedition, in effect, opened up the area to ranching, an economic practice that continues in this region to the present day.

\subsubsection{Ute-Euroamerican Conflicts}

The bands of Ute Indians residing in northwestern Colorado had been trading first with the Spanish, and later the Americans, for nearly 200 years prior to the Colorado gold rush and before Colorado became a territory in 1861. Although they were no strangers to the various groups of Euroamericans that had ventured into their homelands, relationships were relatively peaceful and the Ute had been virtually left alone. The adoption of the horse into their culture centuries earlier gave them the increased mobility to expand their hunting territories. Following the victory of the Mexican War, Americans began pushing farther into Ute territories.

This pressure between the Ute and the Americans resulted in the first official treaty with the tribe, the Calhoun Treaty of 1849, in which all seven bands of Ute agreed to stay within their traditional hunting territories. However, increasing numbers of miners and farmers moving into Western Colorado resulted in increased conflicts with the Ute. In 1863, the U.S. Government, by way of the Evans Treaty, identified reservation land for the Ute for the first time. This treaty was never put in place because the government failed to provide rations to the Ute, who continued hunting and raiding on what was now thought of as settler's land. As a result, the Hunt Treaty of 1868 forced all Ute to move to one reservation totaling approximately one-third of the Colorado territory. Two agencies were established as a result; one was the White River Agency located along the river near present-day Meeker, Colorado (Husband 1984). The second agency was established at Ouray, Utah.

The Ute relations with the White River Agency were uneasy from its inception. The situation turned violent when Nathan Cook Meeker took over the agency in 1878. Meeker was a 
strong proponent of converting the Ute to agriculturalists. By the summer of 1879, Meeker was eager to have more of the reservation land under cultivation. He ordered the Ute to give up a horse racing track that they had constructed so that the field could be cultivated. He also decided that the Ute should kill some of their animals to lessen the grazing burden on the land. Outraged, Chief Johnson, one of three Ute chiefs residing on the reservation, confronted Meeker and a scuffle ensued; Meeker was pushed into a hitching post (Athearn 1982).

Meeker reported this incident and requested assistance from the U.S. Army and the Bureau of Indian Affairs. Eventually Major Thomas T. Thornburgh was dispatched with troops to assist Meeker in controlling the Ute. En route to the reservation Thornburgh encountered a group of Ute without incident; however, a run-in with a second group resulted in a day-long bloody battle in which Thornburgh and 50 others, the majority of them officers, were killed. One of Thornburgh's men rode 28 hours back to Rawlins, Wyoming, to report the battle.

At the same time that Thornburgh and the Ute were in battle, skirmishes were breaking out at the White River Agency, resulting in the "Meeker" Massacre, when all 11 white men at the agency were killed (Athearn 1982). The "Meeker" Massacre was the catalyst in the eventual removal of the Ute from the White River area to Utah several years later (Athearn 1982; Husband 1984). In 1881, the federal government forcibly removed members of the Yamparika and Parianuc bands (known as the White River Ute) to the Uintah Reservation in Eastern Utah. The Taviwac (Uncompahgre Ute), led by Chief Ouray, could not escape removal, but managed to obtain their own reservation in 1882; the Ouray Reservation, situated on the Tavaputs Plateau immediately south of the Uintah Reservation. The two reservations maintained separate agencies at Whiterocks and Ouray until the Bureau of Indian Affairs merged their administration in 1886. The Indian agency was moved from Whiterocks to Fort Duchesne after the military post closed in 1912 (Schirer 1994).

\subsubsection{Cattle and Sheep Industries}

As pressures to remove the Ute Indians from northwestern Colorado were building, small settlements of Euroamericans were being established in this part of the state. The 1880s, 1890s, and 1900s were known as the heyday of open range cattle ranching in the region. The Little Snake, Yampa, and White River valleys were generally good enough to support large herds of cattle. By the 1880s, the White River was known as a prime cattle-producing area in Colorado. The cattle were driven from Meeker through Douglas Canyon across Douglas Pass to Rifle, Colorado, where they could be herded onto railroads to be shipped east. Since there were no roads to Rifle until 1879, the cattle had been driven via the JQS cattle trail onto the Roan Cliffs and into the Piceance Creek Basin (Athearn 1982:71).

As in other areas of Colorado, the cattle industry feared that the increasing sheep herding industry would provide serious competition for the cattle ranchers. "Sheep wars" broke out amongst cattlemen and sheep herders during the 1890s and 1900s as sheep were driven farther into the cattle country of Colorado. In 1920, the sheep wars culminated in reorganization of grazing rights in Colorado. In 1934, the Taylor Grazing Service was created to control and allot lands to the cattle ranchers, sheep herders, and others requesting grazing rights. The Taylor 
Grazing Service eventually merged with the General Land Office to form the BLM, which to this day controls grazing rights through the issuance of permits. These events led to the end of open range cattle grazing (Athearn 1982; Husband 1984).

\subsubsection{Coal and Oil Exploration}

During the 1870 s, coal was discovered in western Colorado. While the most active coal mining areas were located to the east and south of the Piceance Creek Basin area, the Piceance Creek and White River area was explored for coal circa 1890. The closest coal fields found near the region were located between the White and Yampa Rivers southwest of Craig, Colorado (Athearn 1982; Husband 1984).

During the boom in the ranching and mining industries in northwestern Colorado, another form of mining was being explored. There was knowledge of oil in northwestern Colorado as early as the 1890s, and an oil field near Rangely was producing oil, albeit in a costly fashion, during the first half of the century. However, the industry did not boom until the demand for oil rose during and after World War II. At this time, oil fields near Rangely and its vicinity were brought into major production, including the Iles, Hiawatha, and White River fields (Athearn 1982; Husband 1984).

Enthusiasm was also building over the prospect of oil shale deposits in the region. Oilbearing shale, located in Rio Blanco, Garfield, and Moffat Counties drew the oil industry to the area to experiment with various oil recovery methods that could be applied to the shale. The Mahogany Zone, which is part of the Green River Formation, contains west-central Colorado's main shale deposits. It outcrops from the Roan Cliffs near Rifle, Colorado, north and west to Wyoming and Utah, including in the Piceance Basin (Husband 1984; Mehls 1982). The town of DeBeque, Colorado, located on the southern edge of the Piceance Creek Basin, became known as the shale oil capitol of the United States, drawing more than 100 oil shale companies by 1920. Despite efforts, no economically feasible way to recover the oil from the shale was found at that time, and the industry saw a series of ups and downs as these efforts continued (Husband 1984).

This cycle continued to be a problem throughout the twentieth century. The government and the oil corporations continually raised interest in developing an effective means of producing oil from the shale outcrops in northwestern Colorado and in other areas of the West. As late as 1980, Exxon Corporation announced plans to build a 5-million-barrel-per-day oil shale plant near Parachute, Colorado. In 1982, it announced that it was shelving the plans because the production was too costly and not necessary, which left the town of Parachute in an economic slump (Mehls 1982). 


\subsection{PREVIOUS RESEARCH}

\subsubsection{Surveys and Overviews}

Reports of ruins and other archaeological sites in the region around the Piceance Basin accumulated for years before the first trained archaeologists began working in the area (Spangler 2002:36-37). Escalante's journal account from 1776 compares pottery found in northwestern Colorado with similar material observed farther south. His journal also notes some distinctive rock paintings in the Douglas Creek area. Other reports of ruins and rock art filtered in through the late nineteenth and early twentieth centuries from the accounts of travelers and scientists. In the 1920s, Will McKern attempted a systematic study of regional rock art, including the Craig site in the Piceance Basin.

The first trained archaeologists arrived in northwestern Colorado in the 1930s. Researchers explored the Yampa River, and much work was focused in the area of Dinosaur National Monument. In 1933, the Penrose-Taylor Expedition investigated five cave sites on the Yampa River (Spangler 2002:36-37). This work continued through the 1940s and 1950s with excavations at more than 20 caves and rock shelters in the Castle Park area. These excavations were conducted by amateurs and by professional archaeologists from the University of Colorado Museum and the National Park Service (Spangler 2002:47-51). The first comprehensive survey work in the region was undertaken for the University of Denver in 1950 by Gilbert Wenger (Spangler 2002:54-56). Wenger's surveys focused on the Blue Mountain and Douglas Creek areas, where he recorded rock shelters and open architectural sites. Wenger was the first archaeologist to recognize Fremont-like occupations in northwestern Colorado and to hypothesize a part-time forager-horticulturalist subsistence strategy on the part of the prehistoric inhabitants.

Through the latter half of the twentieth century, institutional work in northwestern Colorado was firmly centered on the area in and around Dinosaur National Monument. From 1963 to 1965, teams from the University of Colorado under David Breternitz conducted a systematic survey with the intent of developing an archaeological base map of the park (Spangler 2002:64-65). The survey was followed up by excavations at several rock shelters and open sites. Deluge Shelter, excavated in 1966, was one of these and is a key site in the region (Spangler 2002:70-75). Deluge Shelter contained deep, stratified deposits ranging in age from late Paleoindian through historic times, but with a substantial Archaic sequence. With the radiocarbon dating of several components, the site provides good evidence for an abandonment of horticulture by late Fremont peoples, cultural continuity between Archaic and Formative cultures, and overlapping Plains and Great Basin cultural influences from the Paleoindian through Middle Archaic Periods, with eventual dominance of Great Basin cultural expressions by Late Archaic times. Work in Dinosaur National Monument continued through the 1970s with more excavations and rock art studies by the University of Colorado (Spangler 2002:75-76). In the 1980s and 1990s, National Park Service archaeologist Jim Truesdale excavated several additional sites and analyzed previous work to produce a clearer chronology and an important synthesis of regional prehistory for northwestern Colorado (Spangler 2002:98-99). 
In the late 1970s, Colorado State University (CSU) conducted archaeological investigations in the Douglas Creek area south of Rangely (LaPoint et al. 1981; Spangler 2002:81-84). This work included intensive surveys of the drainage in 1976 to 1977 and 1979. Test excavations were conducted in 1978 at the Brady site and Dripping Brow Cave (5RB699), both of which are stratified, and at two open sites. All of these sites were radiocarbon-dated. Additional work was conducted at Dripping Brow Cave in 1979, where three stratified, radiocarbon-dated components were found associated with Late Archaic, Fremont, and protohistoric Shoshonean peoples (LaPoint et al. 1981).

Academic archaeological work in the Douglas Creek drainage continued sporadically over the next 20 years (Spangler 2002:83-84). In 1983, Western Wyoming College investigated a Fremont masonry structure at Texas Creek Overlook. In 1990, Colorado Northwestern Community College and the Archaeological Research Institute of Bountiful, Utah, excavated stratified Archaic-Formative deposits at Hanging Hearth Rockshelter.

With the advent of effective implementation of federal historic preservation laws in the 1970s, the need to quantify the number and understand the patterned distribution of prehistoric sites in areas targeted for mineral development resulted in the first attempts at predictive modeling (Figure 2-1). In the Piceance Basin, such work was initially undertaken by CSU in 1973 to 1974 (Hurlbett 1976; Spangler 2002:144-145). Their study area included oil shale lands covering 768,000 acres in the basin. A sample area of 40,280 acres was surveyed, resulting in the discovery of 126 prehistoric and historic sites. Site locations were keyed to more than three dozen environmental variables, of which four were determined to have most influenced site location: elevation, proximity to primary and secondary drainages, and local topographic variability. Topographic settings most favorable for prehistoric human occupation were moist areas that supported more vegetation growth and soil development, and south- and east-facing upland slopes where exposure to sunlight is greater. In terms of vegetational association, sites are more likely to be located in sagebrush shrub lands and low-elevation piñon-juniper woodlands. Vegetation-related associations cannot be projected too far into the past given known paleoclimatic changes and their probable effect on prehistoric vegetation patterns.

This initial Class II study was expanded by follow-up work that incorporated subsequent cultural resource management (CRM) survey results from the Naval Oil Shale Reserve and the Rio Blanco Oil Shale Project (Grady 1980; Spangler 2002:166-167). Most of the prehistoric sites in those areas were found to be temporary camps or lithic work stations. Relationships with environmental variables indicated that sites were concentrated near water sources, that no sites were found on slopes of greater than 20 degrees, and that soil types did not correlate with site locations. Other patterns in the data led investigators to conclude that widely distributed small sites in lowlands were related to plant resource exploitation, while highly clustered sites at higher elevations were mule deer hunting camps.

Subsequent, more theoretically rigorous, modeling was undertaken by Newkirk and Roper (1983) with previously acquired site data from the Piceance Basin. These investigators attempted to fine-tune prehistoric settlement models by assigning functions and dates to sites and examining the resulting distribution patterns. A preliminary model was developed by using existing data from 380 sites and isolated finds on 71,529 acres recorded during six different 


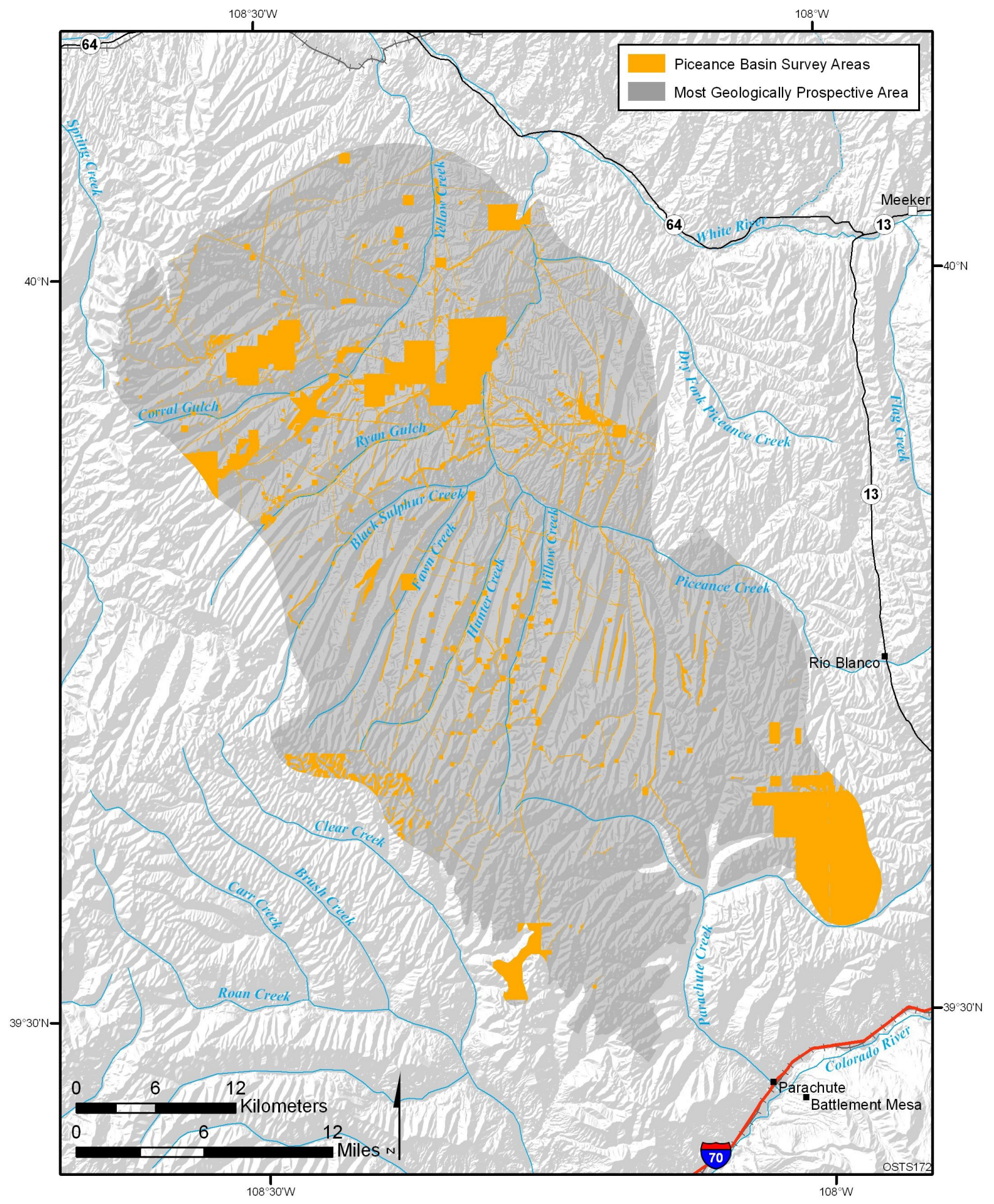

FIGURE 2-1 Cultural Resource Surveys in the Piceance Basin, Northwestern Colorado 
surveys. Stream rank, vegetation zone, relief, and aspect were found to be relevant to site location, while topography and soil type were not. This model was then tested by surveying a stratified random sample of seventy-two 160-acre units. Despite an improved theoretical perspective, results were not much of an improvement over previous modeling attempts. Investigators found that site density decreased with distance from major streams. Two general site types - extractive camps and base camps-were defined on the basis of the variety of tool types present. Their conclusions fell far short of the comprehensive model that had been envisioned.

In 1999, the Colorado Council of Professional Archaeologists published an up-to-date, comprehensive prehistoric context statement for the northern Colorado River Basin, which serves as the current standard for archaeological research design in the Piceance Basin (Reed and Metcalf 1999). This work summarizes the known cultural resources, including previous archaeological work, and summarizes (by period) the current understanding of prehistoric lifeways from Paleoindian through Protohistoric times. Paleoenvironmental reconstructions for the region are considered incomplete and contradictory; in part, because of localized geographic factors (such as orographic uplift) that create significant microclimatic variation. From a more comprehensive regional list presented by Reed and Metcalf (1999:44-52), a shorter list of site types specific to the Piceance Basin includes (1) open artifact scatters, (2) sheltered artifact scatters (i.e., rock shelters), (3) open architectural sites (with wickiup remains), (4) rock art (petroglyphs), and (5) isolated features (hearths or fire pits).

A comprehensive reexamination of archaeological site patterning was recently conducted for the Roan Plateau area, just south of the Piceance Basin (Hoefer et al. 2002). This study was conducted by RMC Consultants for the BLM. The investigation identified patterns in existing site data across some 127,000 acres of the Roan Plateau Management Area. The study confirmed the conclusions of earlier predictive modeling efforts but also produced new insights. Lowland prehistoric sites evidence a greater variety of functional types, contain a greater variety and higher frequency of features, and are more likely to be situated in association with piñon-juniper vegetation than are upland sites. The study defined zones of high and low sensitivity for archaeological sites and recommended improved field methods for archaeological survey and testing projects.

In the nearby Douglas Creek drainage, numerous CRM-based surveys and excavations have taken place. In 1985, excavations took place at Hummingbird Rockshelter where multiple Archaic and Fremont occupations were identified (Spangler 2002:177-178). From 1989 to 1993, Century Research surveyed almost 3,000 acres on Douglas Creek and discovered 80 prehistoric sites (Spangler 2002:178-183). Fourteen of these sites were excavated, including adobe-masonry seed corn storage structures, ephemeral hunter-gatherer residential camps, and sedentary residences with evidence for horticulture and intensive hunting and gathering. After extensive radiocarbon dating, the storage structures and sedentary sites were attributed to Fremont occupations while the ephemeral camps were attributed to later Numic peoples. ArcheologicalEnvironmental Research Corporation excavated 14 prehistoric sites on a natural gas pipeline right-of-way south of Rangely from 1988 to 1992 (Spangler 2002:183-187). These sites included Formative and Shoshonean camps and rock shelters with stratified Archaic and Formative components. 
In the Piceance Basin, CRM work has produced much less substantive results. The following paragraphs summarize some of the larger surveys undertaken in the basin. The discussion is arranged chronologically and includes mention of highlights of these compliance efforts-especially contributions to regional research questions.

In 1976, the Laboratory of Public Archaeology (LOPA) of CSU continued what would eventually become a long-term involvement with northwestern Colorado prehistory by undertaking a survey on several oil shale lease tracts, including tracts in the Piceance Basin (Weber et al. 1977). The results of this survey would later be incorporated into the development of predictive models developed by Hurlbett (1976) and Grady (1980). The survey recorded 94 prehistoric sites on 6 tracts. Most of the sites are lithic scatters and open encampments of unknown prehistoric affiliation. About one-third of them contain dateable pottery sherds or projectile points, and a couple feature the remains of wickiups or log structures. The major findings of this survey were twofold. First, seven more sites with Fremont Turner Gray pottery were found in the Piceance Basin. According to the LOPA researchers, this firmly established a Fremont presence in the basin - at least as hunter-gatherers - contrary to previous expectations (Weber et al. 1977:228-229). Secondly, since the majority of recovered projectile points dated to recent prehistoric times, the implications were either that the basin had been occupied more intensively at these times, or that older archaeological deposits had been washed away by erosion or buried by eolian, colluvial, and alluvial processes (Weber et al. 1977:229-239). The question of Fremont affiliation is still in contention among researchers interested in the Piceance Basin, and the problem of potential deeply buried sites still has not been answered for this region. Aside from this survey, LOPA also conducted test excavations at Square S Rockshelter (5RB271) on Piceance Creek, opening up four 6- $\mathrm{ft}$ by 6 - $\mathrm{ft}$ squares within the shelter and profiling a road cut through the talus just outside the shelter (Grady 1980:354-360).

In 1977 and 1978, LOPA returned to the Piceance Basin to survey tracts involved in a land exchange between the BLM and Superior Oil Company (Price 1978). It located 19 sites and test-excavated 3 of them. These were an open site on a stream terrace (5RB203), an open site on an upland ridge (5RB215), and a rock shelter (5RB204) - all of which contained undisturbed, buried deposits and were determined to be National Register of Historic Places (NRHP) eligible. Survey results supported earlier hypotheses that (1) prehistoric utilization of upland terrain was limited in contrast to valley bottoms, which saw more intensive use, and (2) locations with southand east-facing exposures would be favored in upland settings. Excavations indicated that soils on upland sites would typically be very shallow and lack stratigraphy.

In 1982, the BLM White River Field Office conducted an in-house survey of 5,100 acres on Colorado Oil Shale Lease Tract C-a, located at the headwaters of Corral and Box Elder Gulches in the northwestern Piceance Basin (McPherson 1983). The survey recorded 19 prehistoric sites and 58 isolated finds, and an historic horse trap. Radiocarbon assays were obtained from surface-exposed hearths and preserved wood from five sites. Thirteen sites were considered NRHP eligible or potentially eligible, but follow-up investigations have not been undertaken. Survey results documented a resource density (sites and isolates together) of 1 per 62.9 acres. The prevalent site type appeared to be camps occupied once or twice and then abandoned. Investigators recommended excavating and radiocarbon-dating several of these single-component sites, so that a cultural chronology for the Piceance Basin could be developed 
in the absence of deeply stratified sites. Thus, small, single-component sites were considered important (in terms of NRHP eligibility) because together they could provide needed chronological data (McPherson 1983:111-112). Prehistoric camps found in the survey tract were thought to represent habitation sites from only a portion of a broader subsistence round that encompassed the entire Piceance Basin and probably neighboring valleys as well. Other survey results confirmed a Fremont presence in upland landscape settings and demonstrated a continuous, albeit seasonal, presence of Fremont and Numic groups throughout the basin up to the historic present (McPherson 1983:120). Surveyors noted the possibility that buried sites might exist at depositional locales atop ridges. McPherson (1983:121) stressed that many research topics relevant to the prehistory of the Piceance Basin (including paleoenvironmental reconstruction, feature form and function, and the seasonality and duration of site occupations) could not be addressed through survey, and a program of controlled excavation at selected prehistoric sites would be required before management decisions regarding site significance and preservation could be based upon well-researched data.

Just south of the Piceance Basin, on Parachute Creek, a 1982 to 1983 survey covered some 16,000 acres of Union Oil Company's Shale Oil Program expansion (Conner and Langdon 1983). That survey recorded 17 historic sites, 19 prehistoric sites, and 7 isolated finds. One prehistoric rock shelter site was deemed NRHP eligible, while 10 prehistoric campsites with exposed features or likely buried cultural deposits were considered potentially eligible. Two well-preserved historic dugouts and a pioneer cabin were also considered NRHP eligible. Three historic residences with undisturbed subsurface features and an historic oil shale haul road were classified as potentially eligible for the NRHP.

In the southern part of the Piceance Basin, a survey of the 6,140-acre Pacific Shale Project (Newkirk and Bambrey 1983) specifically compared results with predictive modeling parameters outlined by Newkirk and Roper (1983) for the northern part of the basin. Researchers documented a density of 1 site per 885 acres. They concluded that the model was correct in that site density does decrease with distance from major streams, and that sites are more frequent in areas of lower relief. In contrast with the model, they found that sites are more frequent in open, level settings rather than on southerly exposures.

In 1991, Alpine Archaeological Consultants, Inc., began a multistate survey for the TransColorado natural gas pipeline corridor that passed through the Piceance Basin (Reed and Horn 1992). Site frequency predicted prior to fieldwork was exceeded slightly by the actual results, but overall trends in site density were confirmed. Low site density in the Piceance Basin was quantified by a figure of 0.3 sites per kilometer along this linear survey transect (Reed and Horn 1992:513).

Survey by Metcalf Archaeological Consultants, Inc., along the Colorado Interstate Gas (CIG) Uinta Basin Lateral Pipeline, included a section that passed through the northern Piceance Basin (Pennefather-O'Brien et al. 1992). Although only four prehistoric sites were encountered along that section, the results were compared with earlier predictive models. By comparison with Grady (1980), they found that distance to water (within $200 \mathrm{~m}$ ), slope of less than 20 degrees, and open aspect were all relevant environmental factors. Correlation with vegetation type was somewhat equivocal. Importantly, they noted that these factors appear to be important 
determinants of site location, but that the same environmental factors occur in many locations where no sites occur, suggesting that other factors must be considered before site location can be accurately predicted (Pennefather-O'Brien et al. 1992:240). Their results were also compared with the predictive model generated by Newkirk and Roper (1983). The Metcalf researchers found that vegetation type (rabbitbrush-sagebrush and piñon-juniper) and low relief were the most accurate predictive variables in that model.

A typical energy-related Class III linear survey was undertaken in the Piceance Basin by CRM archaeologists from the Grand River Institute in 1994 (Grand River Institute 1994). The survey covered a 25-mi pipeline corridor and two 10-acre tracts for compressor stations at each end of it. The linear survey area extended from central Rio Blanco County, south across Piceance Creek to Parachute Creek in Garfield County, covering 617 acres total. Investigators discovered two isolated prehistoric artifacts and a small lithic scatter, which was assigned to the Late Prehistoric Period. Since the site was located just outside the proposed impact area, no further archaeological investigations were recommended; although had it been found inside the impact area, it would have been test-excavated in order to evaluate its historic significance. The two isolated finds were not considered significant.

East of Parachute Creek on Naval Oil Shale Reserve Tracts 1 and 3, archaeological survey was conducted by Alpine Archaeological Consultants in 1995 to 1996 (Tickner et al. 1996). That survey covered 18,448 acres on and below the Roan Plateau. The work encountered 29 historic sites, 91 prehistoric sites, and 69 isolated finds. Historic sites include an early twentieth century oil shale plant and associated features, and livestock grazingrelated sites. Prehistoric sites were almost entirely lithic scatters, but with one site containing preserved wickiups. Thirty sites were considered eligible for NRHP listing.

Beginning in 1998, archaeological compliance work began at the Yankee Gulch Sodium Minerals Project west of Piceance Creek. In that year, Grand River Institute conducted a Class III Inventory, recording a total of 42 prehistoric sites, 40 prehistoric isolates, 6 prehistoric isolated features, and 5 historic sites (Conner et al. 1998:30). Altogether, a "resource density" of 1 per 72 acres (or 8.8 resources per $\mathrm{mi}^{2}$ ) was calculated-more than twice as high as that encountered on an adjacent tract. The higher site density in the Yankee Gulch Project was attributed to the proximity of Piceance Creek. Nineteen sites were classified as NRHP eligible or potentially eligible. A "cultural resources treatment plan" was developed as a sort of research design by which the sites in the Yankee Gulch were to be evaluated (Steigers Corporation 1999). Four prehistoric sites and a Historic Ute camp in the area were later test-excavated (Conner and Davenport 2000; Harrison and Conner 2000).

Also in 1998, Grand River Institute (1998a) surveyed 1,430 acres on the Garfield-Rio Blanco County line northwest of Rifle, Colorado. This survey was conducted in advance of an exchange of private land held by Union Oil of California and public lands administered by the BLM and on the Naval Oil Shale Reserve. Fieldwork encountered 3 prehistoric sites, 4 historic sites, and 18 isolated historic and prehistoric finds. All but 1 prehistoric site was deemed not eligible for NRHP listing. 
A typical oil field-type archaeological survey in the basin was undertaken by Montgomery Archaeological Consultants in 1999 (Montgomery and Wolfe 2000). The survey covered four proposed 10-acre well pads and about $3 \mathrm{mi}$ of proposed access roads north of Yellow Creek. Investigations discovered three isolated prehistoric artifacts, one small prehistoric site (5RB4197), and a wild horse corral dating to the 1940s. Neither the corral nor the isolates were considered historically significant. Site 5RB4197 is located in piñon-juniper woodland and it contained 6 flakes, a biface, a point midsection, 10 burned rocks, and a hearth feature. It was considered potentially eligible for NRHP listing, but no additional archaeological work was conducted there since the site was located more than $100 \mathrm{ft}$ from the actual impact area for proposed well pad construction.

In 1994, Alpine Archaeological Consultants conducted a survey for the multicounty Entrega Gas pipeline, which passed through the Piceance Basin (Redman and Chandler 2004). They developed research questions that stressed environmental factors and the relationship to prehistoric cultural adaptations. These included the correlation between site density and the food potential of vegetation zones, change in prehistoric settlement patterns over time in response to changing climatic conditions, and variation in site size and complexity by elevation.

Surprisingly, they found that the sagebrush vegetation zone produced an unexpectedly high frequency of sites, higher even than the piñon-juniper zone, contrary to previous models. They also found that there was little difference in settlement pattern over time, with most sites from all time periods being located on moderate slopes with some exposure to the sun, and in the vicinity of permanent water (Redman and Chandler 2004:317). Their data did confirm that the largest and most complex sites were concentrated at lower elevations.

A series of five-block-area CRM surveys was conducted in the Piceance Basin from 2001 to 2005 (Conner and Davenport 2001a,b,c; Conner et al. 2004b, 2005a). These were all undertaken by Grand River Institute for Shell Frontier Oil \& Gas in advance of land exchanges and developments associated with well drilling. Three Shell RD\&D tracts (Oil Shale Test Site, Nahcolite Test Site, and Advanced Heater Test Site) are located within these surveyed areas. The surveys covered some 11,300 acres, parts of which overlapped with previously surveyed tracts. Three historic sites, 29 prehistoric sites, and 39 isolated prehistoric artifacts were documented in the 5 survey tracts. Of these, only 12 prehistoric sites were considered potentially eligible for NRHP listing and were recommended for further testing to determine eligibility, or avoidance if possible. One of the potentially eligible prehistoric sites (5RB4296) is located in the same tract as the Advanced Heater Test Site. No archaeological sites were found in the Oil Shale Test Site.

In 2006, surveys were undertaken for the three other 160-acre oil shale RD\&D tracts in the Piceance Basin. Cultural Resource Analysts, Inc., surveyed a block area and an associated utility line corridor for the EGL Oil Shale RD\&D tract near Sulphur Creek in Rio Blanco County (Greenberg 2006; Hoefer and Greenberg 2006). Archaeologists found two prehistoric lithic scatters, two prehistoric isolates, and two historic isolated artifacts. None of these cultural resources were considered historically significant, and archaeological clearance was recommended for the survey areas. Grand River Institute surveyed the Nahcolite Test Site for Shell Frontier Oil \& Gas and found no cultural resources in the 160-acre area (Darnell 2006). Grand River Institute also surveyed the Chevron lease tract and an associated utility line route (Connor 2006a,b). No cultural resources were found in that RD\&D tract either. 


\subsubsection{General Observations}

\subsubsection{Rock Shelters}

Some types of archaeological sites are more likely to produce important data than others. The rock shelter is a site type that possesses the most potential for containing well-preserved, deeply stratified cultural deposits. For geological reasons, however, rock shelters are rare in the Piceance Basin. Local bedrock exposures of the Uinta Formation do not typically weather in such a way as to form shelters with deep overhangs, unlike the Mesa Verde Formation sandstone that outcrops in the neighboring Douglas Creek valley, where rock shelters are plentiful (Conner and Davenport 2001c:17).

In the Piceance Basin, rock shelter sites-when they are found-are typically considered to have NRHP potential, but only five such sites have actually been test excavated. The shelter at 5RB2765 was found to contain a thin veneer of cultural deposits over a shallowly buried bedrock floor, and for that reason was determined not eligible for NRHP listing (Zier and Jepson 1991). The other four tested rock shelters (5RB123, 5RB204, 5RB271, and 5RB2764) all contain deep cultural deposits and are considered NRHP eligible.

The Burke site (5RB123) is a rock shelter that was excavated in 1972 by CSU. The results of the excavations have never been fully reported but are mentioned in a later CRM report by Zier and Jepson (1991). Excavations produced Great Salt Lake Gray ceramics attributed to the fourth century A.D., and radiocarbon dates from the Late Prehistoric Period.

Rock shelter 5RB204 was test excavated in 1977 by CSU as part of an archaeological compliance survey (Price 1978). A narrow test trench exposed alluvium overlaying sandy midden deposits. Both of these levels produced projectile points attributed to Fremont occupations. Faunal material included rabbit, prairie dog, rat, large ruminant, and two species of fish. Identified floral remains consisted only of prickly pear. Analysis of the organic materials was limited to a comparison between counts of fish and rabbit bone (which were roughly equal) and the observation that nearly all of the materials were unburned. This led the investigator to question whether fish and rabbit had been used as food sources prehistorically. No radiocarbon assays were reported, and no mention is made of concern for paleoenvironmental studies (Price 1978).

Of these four significant rock shelters, only the investigations at 5RB271- the Square S Rock Shelter - have been published (Grady 1980:354-360); that report was preliminary, however, and did not include a full analysis or discussion of the cultural stratigraphy or environmental data. With $8 \mathrm{ft}$ of stratified deposits and at least 10 readily visible occupation zones, the site contains an enormous potential for reconstructing past environmental conditions and defining a large part of the prehistoric cultural sequence for the Piceance Basin. But no additional work has been undertaken at the site subsequent to the 1976 testing by CSU. The radiocarbon, pollen, and sediment samples, and well-preserved floral and faunal remains recovered from packrat middens have not been analyzed in the more than three decades since the site was test-excavated. 
Rock shelter 5RB2764 was test-excavated as part of compliance work by Centennial Archaeology, Inc. (Zier and Jepson 1991). Limited excavation there exposed $2.5 \mathrm{~m}$ of deposits and three superimposed occupation zones. Excavations produced no temporally diagnostic artifacts, but four radiocarbon assays dated the upper levels to A.D. 250 to 1000. Older cultural deposits were thought to be present in deeper levels that had not been excavated. Flotation samples were collected from three superimposed hearths, one of which produced only charcoal. The other two contained the remains of two species of edible wild plants, which led investigators to suggest that plant food processing was the major activity of the prehistoric inhabitants (Zier and Jepson 1991:80-82). No paleoenvironmental research (pollen or sediment analysis) was undertaken, despite the call for such studies as stated in numerous earlier reports and research designs.

\subsubsection{Wickiup Camps}

Despite the lack of any concerted effort to fully investigate key prehistoric sites in the Piceance Basin, small advances are occasionally made through the course of accumulated work during standard compliance surveys and the infrequent site evaluations. For example, a local site type has come to be recognized in the last decade. This is the open architectural site, or wickiup camp. Such sites had not been previously recognized because the log remains are often fallen and appear as nothing more than a few dead juniper logs. In some cases, logs may have been removed in recent times. This appears to have occurred more often at wickiup camps located near existing access roads, where ancient poles are more likely to have been collected by ranchers for use as fence posts or gathered by modern hunters for use as firewood (Brown and Selle 2001:27; Conner and Davenport 2005:14). Where standing log structures are still present, the remains may not consist of anything more than a single log leaning up against a live tree. Conner and Davenport (2001c:17) assert that wickiups were probably used prehistorically at all open camps located in upland settings in piñon-juniper woodland. Such camps are considered remnants of short-term occupations, and typically contain at least one hearth or fire pit, and a light scatter of stone tools and lithic debitage. Sites 5RB215, 5RB446, 5RB2275, 5RB2929, 5RB3955, 5RB3956, and 5RB3989 are all upland open camps that have been test-excavated. At four of these sites, hearth features and shallowly buried cultural deposits were found intact along with the remains of wickiups in some cases (Price 1978). These sites were evaluated as NRHP eligible. Sites 5RB446, 5RB3956, and 5RB3989 were evaluated as not eligible because cultural deposits were found only on the ground surface, or were shallowly buried but severely disturbed by erosion and/or "chaining" activity.

\subsubsection{Fire Suppression and Architectural Sites}

Fire suppression and management activity by federal agencies has had a profoundly negative effect on some prehistoric sites in parts of the Piceance Basin. As part of grazing management operations undertaken primarily in the 1960s, the BLM undertook chaining-a process that involved stretching a heavy chain between two bulldozers which then worked in tandem to tear down swaths of brush and piñon-juniper woodland. Chaining rips trees and brush out of the ground and drags the debris along, disturbing the upper 4 in. or more of soil. The 
process has obvious detrimental effects to the shallow archeological deposits found at many prehistoric sites in the Piceance Basin; it also leaves behind huge windrows of dead wood and brush that provide fuel for wildfires. The direct effect of chaining on the standing remains of prehistoric log wickiups and certain historic features (such as horse traps, pens, corrals, and drift fences) is devastating. Of course, wildfire itself has the potential to destroy wooden cultural resources as well. This fact presents a paradox for land managers when considering the options between various fire suppression techniques, including the construction of fire breaks and the mechanical removal of potential fuel for wildfires (Brown and Selle 2001:26-27). Adequate inventory is the obvious first step needed toward identifying any log structures and shallow archeological sites that might be present in areas of planned fire suppression activity. Armed with such locational data, managers can plan and direct fire reduction efforts in order to protect cultural resources identified in such areas.

\subsubsection{Effectiveness of Predictive Models}

The seminal survey work in the Piceance Basin region attempted to identify environmental factors responsible for the patterning of prehistoric site locations. Models developed by Hurlbett (1976) and Grady (1980) have had some success in this regard. These studies linked site locations with critical variables such as elevation, slope, aspect, and proximity to water and certain seasonally available plant and animal resources. Later modeling by Newkirk and Roper (1983) and Hoefer et al. (2002) confirmed the importance of these variables and refined earlier conclusions. Site density predictions were tested in the context of compliance survey by Reed and Horn (1992:513), who also confirmed overall trends.

More recent work has produced slightly divergent results but otherwise mostly confirmed existing predictive models. Pennefather-O'Brien et al. (1992:240) compared their survey results with those of Grady (1980). They confirmed that proximity to water, slope of less than 20 degrees, and open aspect were all relevant factors, but found that correlation with vegetation type was equivocal. They note that Grady's model does not account for locations where sites do not appear, and that other factors must be considered before site location can be accurately predicted. They also compared their results with those of the model developed by Newkirk and Roper (1983) and found that vegetation type and low relief were the most accurate predictive variables. Redman and Chandler (2004:317) found that the sagebrush vegetation zone produced an unexpectedly high frequency of sites, higher even than the piñon-juniper zone, contrary to previous models. This may be partly explained by the location of their study area, which extends mostly outside the Piceance Basin into the adjacent valleys of Deception and Spring Creeks in Moffat County. But they also found that, as expected, most sites from all time periods were located on moderate slopes with some exposure to the sun, and in the vicinity of permanent water. In general, existing predictive models for prehistoric site location in the Piceance Basin continue to have some utility, but divergent results from recent surveys have not been adequately explained.

Despite slight discrepancies arising from existing models, a comprehensive update that would incorporate all survey data acquired in the last 40 years is probably not needed. No rationale exists for undertaking an update. Existing predictive models do not appear to be 
currently employed for any land management purposes beyond providing a general estimate of the number of sites that might be expected on any given tract. For that purpose, the existing models are adequate.

\subsubsection{Avoidance Option}

Little archaeological work in recent years in the Piceance Basin has added much to the understanding of prehistory in the region (Reed and Metcalf 1999:165). The results of Class III surveys have seldom been amalgamated and synthesized. Compliance work occasionally leads to test excavations at specific sites. Colorado SHPO records indicate that only 16 archaeological sites in the entire Piceance Basin have been test-excavated (see Table 2-1), and none have seen full-scale excavation, analysis, and publication. The few recent excavations have been directed at testing sites for NRHP eligibility, rather than toward problem-oriented research or acquisition of broader knowledge concerning regional prehistoric lifeways. Most sites deemed to contain significant cultural deposits are avoided by planned developments. Because the avoidance option is the most cost-effective and protective of cultural resources, important sites have not been investigated any further. Exercise of the avoidance option has protected archaeological sites from disturbance, but has also restricted advancement of the understanding of regional prehistory through the CRM context.

\subsection{RECORDED SITES}

According to the Colorado SHPO's electronic database (see Appendix A, Table A-2, and Figure 2-2), 1,162 archaeological sites have been identified in the Piceance Basin. The database contains information on 1,041 of the 1,162 sites found in the geologically prospective oil shale area.

Of the 1,041 sites that have data, 486 have been identified as being associated with prehistoric cultures (see Appendix A, Table A-3). In addition, there are 501 prehistoric isolated finds. The isolated finds tend to be chert flakes or a mano or bifacial tool. There are also isolated prehistoric features consisting of Aspen rock art. One hundred and sixty-five prehistoric open camps have been found in the study area. Artifacts associated with the camps include flakes, ground-stone tools, fire-cracked rock, and points. The final type of prehistoric site is the open lithic, which appears to be a variant of the open camp. The 257 open lithic sites $(n=257)$ in the database contain tools such as projectile points, knives as well as chert cores, and flakes that are evidence of tool manufacture. Fifty-one of the sites $(n=51)$ have been determined eligible for listing on the NRHP (see Appendix A, Table A-4). There are 25 sites $(n=25)$ that have been field-determined eligible but have not been formally evaluated. The remaining sites found in the Piceance Basin are from the historic period and include isolated features, isolated finds, architecture, historic roads or trails, an historic trash scatter, and examples of historic era Native American rock art. The isolated features are the remains of log structures, and the isolated finds consist of a rifle cartridge. The historic scatter contains bottle glass, canning jars, and various cans. One example of historic graffiti $(n=1)$ has been recorded. None of the historic sites $(n=0)$ 
TABLE 2-1 Excavated Sites in the Piceance Basin

\begin{tabular}{|c|c|c|c|c|c|c|}
\hline Site & $\begin{array}{c}\text { Year } \\
\text { Excavated }\end{array}$ & $\begin{array}{l}\text { Site Type/ } \\
\text { Setting }\end{array}$ & $\begin{array}{l}\text { Nature of } \\
\text { Deposits }\end{array}$ & $\begin{array}{c}\text { Area } \\
\text { Excavated } \\
\end{array}$ & $\begin{array}{c}\text { NRHP } \\
\text { Eligibility }\end{array}$ & Other \\
\hline $5 \mathrm{GF} 83$ & 1991 & $\begin{array}{l}\text { Streambed/ } \\
\text { alluvial }\end{array}$ & $\begin{array}{l}\text { All surface } \\
\text { scatter }\end{array}$ & $0.5 \mathrm{~m}^{2}$ & No & Severely disturbed \\
\hline $\begin{array}{l}5 \mathrm{RB} 123 \\
\text { (Burke Site) }\end{array}$ & 1972 & Rock shelter & Deep & Unknown & Yes & Intact deposits \\
\hline $5 \mathrm{RB} 203$ & 1978 & Open terrace & Shallow & $4 \mathrm{~m}^{2}$ & Yes & Many features \\
\hline 5RB204 & 1978 & Rock shelter & Deep & $8.6 \mathrm{~m}^{2}$ & Yes & $\mathrm{NA}^{\mathrm{a}}$ \\
\hline $5 \mathrm{RB} 215$ & 1978 & Open ridgetop & Shallow & $4 \mathrm{~m}^{2}$ & Yes & Intact deposits \\
\hline $\begin{array}{l}5 \mathrm{RB} 271 \\
\text { (Square S } \\
\text { Rockshelter) }\end{array}$ & 1976 & Rock shelter & Deep & $13.4 \mathrm{~m}^{2}$ & Yes & NA \\
\hline 5RB446 & 1999 & Open camp & $\begin{array}{l}\text { All surface } \\
\text { scatter }\end{array}$ & $<2 \mathrm{~m}^{2}$ & No & NA \\
\hline $5 \mathrm{RB} 451$ & 2000 & Open camp & Shallow & $2 \mathrm{~m}^{2}$ & No & $\begin{array}{l}\text { Only features had } \\
\text { depth }\end{array}$ \\
\hline $5 \mathrm{RB} 2275$ & 1982 & Open ridgetop & $\begin{array}{l}\text { Potentially } \\
\text { shallow }\end{array}$ & $\begin{array}{l}1 \text { feature } \\
\text { profiled }\end{array}$ & Yes & $\begin{array}{l}\text { Potentially intact } \\
\text { deposits }\end{array}$ \\
\hline 5RB2764 & 1991 & Rock shelter & Deep & $<3 \mathrm{~m}^{2}$ & Yes & NA \\
\hline $5 \mathrm{RB} 2765$ & 1991 & Rock shelter & Shallow & $<3 \mathrm{~m}^{2}$ & No & Eroded \\
\hline 5RB2766 & 1991 & $\begin{array}{l}\text { Open slope } \\
\text { near spring }\end{array}$ & Shallow & $<3 \mathrm{~m}^{2}$ & No & Rodent disturbance \\
\hline 5RB2929 & 1989 & $\begin{array}{l}\text { Open wickiup } \\
\text { camp }\end{array}$ & Shallow & $\begin{array}{l}1 \text { feature } \\
\text { sampled }\end{array}$ & Yes & $\begin{array}{l}\text { Potentially intact } \\
\text { deposits }\end{array}$ \\
\hline 5RB3955 & 1999 & $\begin{array}{l}\text { Open wickiup } \\
\text { camp }\end{array}$ & Shallow & $2 \mathrm{~m}^{2}$ & Yes & Intact deposits \\
\hline 5RB3956 & 1999 & $\begin{array}{l}\text { Open wickiup } \\
\text { camp }\end{array}$ & Shallow & $1 \mathrm{~m}^{2}$ & No & Eroded deposits \\
\hline 5RB3989 & 1999 & Open camp & Shallow & $<2 \mathrm{~m}^{2}$ & No & $\begin{array}{l}\text { Disturbed by chaining } \\
\text { and erosion }\end{array}$ \\
\hline
\end{tabular}

a $\quad \mathrm{NA}=$ not applicable.

are eligible for listing on the NRHP. Eight hundred and twenty-two sites $(n=822)$ have been determined ineligible for listing on the NRHP.

The cultural resource sensitivity map developed as part of this study for the Piceance Basin was based on the relationship between surveyed prehistoric sites and soil families. Our analysis considered the distribution of 680 sites across five soil families. The resulting chi-square analysis determined that sites are definitely not randomly distributed across the landscape. Areas with the soil families mapped as Rock outcrop-Rentsac-Moyerson-Mikim-Atchee and Yamac- 


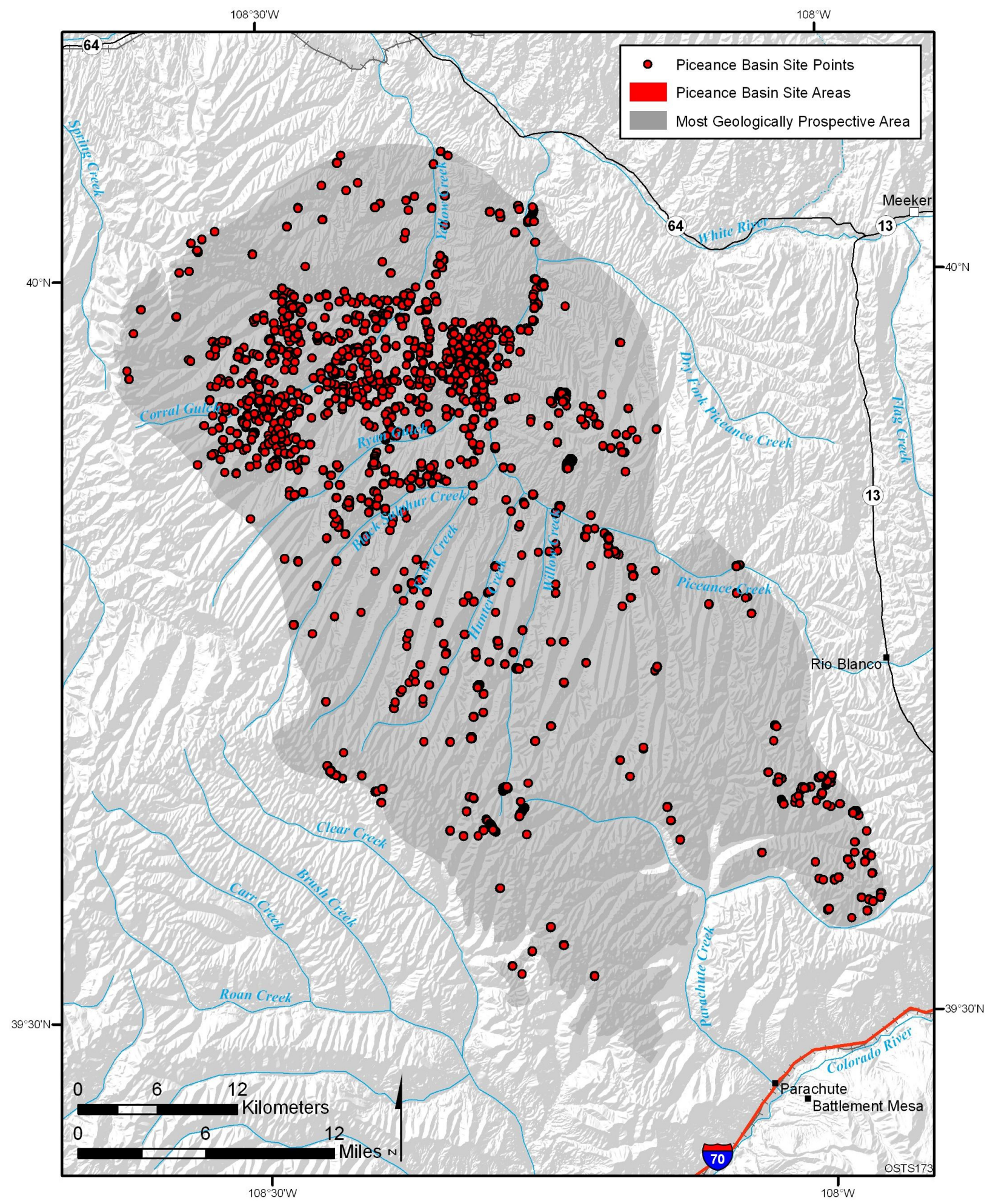

FIGURE 2-2 Cultural Resources in the Piceance Basin, Northwestern Colorado 
Rentsac-Piceance contain inordinately high numbers of sites. These areas correspond to the lower elevations in the central and northern parts of the Piceance Basin (see Figure D-1). Areas mapped with the Starman-Rhone-Parachute-Northwater-Irigul soil family contain roughly the number of sites that might be expected if sites were distributed at random across the landscape, and are thus considered areas of moderate site frequency. These areas correspond to the higher elevations that compose the southern third of the basin. Areas mapped with the Utso variantTosca-Rock outcrop-Happle and Veatch-Rock outcrop-Rentsac-Redcreek-Castner-Abor soil families contain significantly fewer sites than expected. These areas correspond to the middle elevation ridges and valleys that occur as a band running through the western and central part of the Piceance Basin, and in similar mid-elevation valleys along the extreme southern fringe of the study area.

The site distribution pattern is highly evocative (Figure D-1). A contiguous area of high site probability is centered in the bottom of the basin along Piceance and Yellow Creeks and the lower portions of their tributaries. An area of moderate site probability occurs on the highly elevated terrain to the south. These areas are separated by a swath of low site probability.

The arrangement suggests that the lower part of the basin saw greatest use throughout prehistory. This can be attributed to at least three environmental factors. First, the lower basin was most easily accessible to groups entering the Piceance Basin from the Yampa River valley. Secondly, from a seasonal perspective, plant and animal resources would have been available at lower elevations for a longer period than those at higher elevations. Thus, more episodes of resource exploitation should be evidenced by greater numbers of sites at lower elevations. Third, streams converge in the lower part of the Piceance Basin. This topographic fact would have provided prehistoric occupants of the lower basin with an inordinately high number of landscape settings positioned in close proximity to water.

As an aside, it should be noted that our interpretations are tempered by the understanding that sites from all prehistoric time periods were lumped together in the analysis. Thus, chronological differences in settlement patterning may be obscured. Nevertheless, the statistical analysis does identify some robust trends in the overall data, and these trends are still significant.

Moderate site frequency in the highlands suggests prehistoric use of this part of the basin on a restricted seasonal basis. If there was a regular seasonal round that encompassed highland and lowland terrain, the numbers of sites in both areas should be at least comparable. The fewer numbers of highland sites suggests that occasional forays were made to higher elevations but that overall, most resource extraction activity occurred in the lower part of the basin. The swath of low site density at mid-elevations suggests that prehistoric peoples mostly passed through these parts of the landscape on their way to and from the highlands, but found few resources in such settings to necessitate a stop. Evidence for population aggregation in the lower basin is not evidenced, since that would be characterized by fewer sites, not more. That populations did not aggregate at the fewer highland and mid-elevation sites is evidenced by the invariably small size of all sites found in these parts of the Piceance Basin. 


\section{UINTA BASIN AND SPECIAL TAR SAND AREAS, UTAH}

\subsection{ENVIRONMENTAL SETTING}

\subsubsection{Physiography}

The overall Uinta Basin has an area of about 7,000 $\mathrm{mi}^{2}$, bounded by the Uinta Mountains on the north, the Wasatch Range on the west, the Roan Cliffs on the south, and the Douglas Creek Arch on the east (Cashion 1967). The basin is almost entirely in Utah, with a small portion of the overall basin extending into Colorado (see Extent of Green River Formation labeled Uinta Basin in Figure 1-1). The Uinta Basin is a structural, depositional, and topographic/drainage basin. This region is primarily in Uintah County, Utah, with a small western extension into Duchesne County, Utah. Seven of the STSAs (Argyle Canyon, Asphalt Ridge, Hill Creek, P.R. Spring, Pariette, Raven Ridge, and Sunnyside) are located in the Uinta Basin (Figure 1-2).

The four STSAs in southeast-central Utah (San Rafael, Circle Cliffs, Tar Sand Triangle, and White Canyon) are in the Canyonlands section of the Colorado Plateau physiographic province (BLM 1984) (Figure 1-2). San Rafael is located on the San Rafael Swell; White Canyon is on the northwestern flank of the Abajo Mountains; Circle Cliffs is an upland area between the Aquarius Plateau and the Henry Mountains; and the Tar Sand Triangle is located at the southern end of the San Rafael Desert.

\subsubsection{Geology, Soils, and Hydrology}

The Uinta Basin contains a thickness of up to $15,000 \mathrm{ft}$ of lacustrine and fluvial sedimentary rock of Eocene age above older sedimentary formations (Cashion 1967). The uppermost bedrock unit is the Duchesne River Formation of fluvial sandstone and shale. Below this formation is the Uinta Formation of similar lithologies. Below the Uinta is the Green River Formation, which is composed of four members. The uppermost is the Evacuation Creek Member, composed mainly of marlstone and siltstone, and which interfingers with the overlying Uinta Formation. The underlying Garden Gulch and Parachute Creek members are of similar lithologies. The Parachute Creek Member is the main oil shale-bearing member, and it includes the rich Mahogany Zone. The Douglas Creek Member is composed of mixed lithologies, including sandstone, siltstone, and limestone, and it interfingers with the overlying Garden Gulch and Parachute Creek members and the underlying Wasatch Formation. The Wasatch is also an Eocene-age basin-fill unit and is composed of sandstone and shale. Quaternary alluvium is present along the Uinta Basin's major stream valleys.

The seven northern STSAs (Argyle Canyon, Asphalt Ridge, Hill Creek, P.R. Spring, Pariette, Raven Ridge, and Sunnyside) are located in the Uinta Basin, and most are in Tertiary-age sedimentary rocks. The geologic description above applies to most of these sites. The exception is Asphalt Ridge, which is partially in the Cretaceous Mesa Verde Formation 
(BLM 1984). The rock units containing the tar are mostly fluvial sandstones, though some are lacustrine sediments. The bitumen is usually concentrated in the coarser facies of the sediments.

The four southern STSAs (San Rafael, Circle Cliffs, Tar Sand Triangle, and White Canyon) have bedrock of Permian and Triassic ages (BLM 1984). The Tar Sand Triangle is in the Permian White Rim Sandstone, which may be dune sand or shallow marine sand deposits. Bitumen varies at the STSA along with the variations in sand texture and permeability. The Circle Cliffs and San Rafael STSAs are located in the lower Moenkopi Formation. This unit is a large deltaic deposit of fine- to medium-grained, moderately well-sorted sandstone of Triassic age. The White Canyon STSA occurs in the Hoskininni Sandstone, a Triassic shallow marine deposit.

Gilsonite, a black, brittle natural petroleum residue, is found in the Uinta Basin; it occurs as miles-long vertical veins up to $18 \mathrm{ft}$ wide (Cashion 1967). Along the southern portion of the study area are areas that overlap with two STSAs-Hill Creek and P.R. Spring. Oil and gas have been produced from the lower part of the Green River Formation, the Wasatch Formation, and deeper Mesozoic-age rocks.

Other geologic resources are present or possibly present at the 11 STSAs (BLM 1984). Oil and gas are present at P.R. Spring and Pariette, and are likely at Hill Creek and Raven Ridge. Oil and gas are possible, though not highly likely, at Argyle Canyon, Asphalt Ridge, Circle Cliffs, and White Canyon. Oil shale of significant thickness and yield overlies the tar sands deposits along the northern edge of the P.R. Spring and Hill Creek STSAs. The Mahogany Oil Shale Zone is present at the Pariette and Raven Ridge STSAs; however, these oil shale deposits are not included in the oil shale study area defined for the PEIS. Coal of commercial thickness and quality is below the Sunnyside STSA; however, it is at a depth that would require underground rather than surface mining. Coal is possible in Cretaceous rocks below Hill Creek and P.R. Spring. Coal of poor quality is possibly below the tar sands at Asphalt Ridge. Uranium may occur locally at Circle Cliffs, Tar Sand Triangle, and White Canyon STSAs, above the Moenkopi Formation in the Shinarump Conglomerate Member of the Chinle Formation, and at the San Rafael STSA. Copper occurs locally at the San Rafael STSA.

Soils in the Uinta Basin are in two general groupings on the basis of the geomorphological setting (DOI 1973). Most of the basin's flat areas are covered with shallow soils over weathered bedrock. These soils are typically either fine loam or silt over silty or clayey subsoils, or sandy or coarse loamy soils. Shale and/or sandstone bedrock is usually about 20 in. deep. Erosion is high during summer storms. Along the floodplains and terraces of major rivers are deep loamy or silty soils over coarser subsoils. Erosion through stream cutting is high during high flow periods. Overall, the basin's erosion potential is critically high, though some areas are in the slight to moderate range, and some areas have erosion potential that is considered severe.

Soils at the 11 STSAs have a wide range of thicknesses and character because of spatially varying factors such as parent material, climate, topography, and vegetation. Data compiled by the BLM (1984) indicate general conditions in mountainous areas (moist, dark or light) and valley or mesa areas (dry, light-colored). The soils are developed from sandstone, shale, and 
siltstone bedrock and have corresponding textures (e.g., sandy soils near more resistant ridges, clayey soils near shale outcrops). Alluvial fan soils are loamy and bouldery. Slopes vary within individual STSAs and among different STSAs.

The BLM (1984) has evaluated the erosion potential of the STSA soils in terms of sediment yield classification. Overall, the largest category of the STSA land area is that of moderate sediment yield $\left(0.2\right.$ to $\left.0.5 \mathrm{ac}-\mathrm{ft} / \mathrm{mi}^{2} / \mathrm{yr}\right)$, followed by high sediment yield (0.5 to $\left.1.0 \mathrm{ac}-\mathrm{ft} / \mathrm{mi}^{2} / \mathrm{yr}\right) .{ }^{1}$ The San Rafael STSA had the only significant amount of land area $(18 \%)$ at a very high sediment yield (1.0 to $\left.3.0 \mathrm{ac}-\mathrm{ft} / \mathrm{mi}^{2} / \mathrm{yr}\right)$.

The oil shale area within the Uinta Basin is drained, mostly, by the southward flowing Green River and its two major tributaries, the White and Duchesne Rivers. Many perennial and intermittent streams, including Willow, Hill, Bitter, and Evacuation Creeks; Sand and Cottonwood Washes; and Center Fork flow northward to the Green and White Rivers. Pleasant Valley, Big, and Pete's Washes flow eastward into the Green River, and the Coyote Wash flows westward into the White River. Seven of the STSAs are also located in the Uinta Basin, with drainages flowing south-, east-, and westward into the Green River. The other four STSAs south of the Uinta Basin drain into tributaries and other associated intermittent streams of the Colorado and Green Rivers.

Three bedrock aquifers and a number of alluvial aquifers are found in the Uinta Basin. Underlying the Uinta-Duchesne Aquifer is the Parachute Creek Aquifer, which is associated with the main oil shale-bearing sedimentary rocks of the Parachute Creek Member of the Green River Formation.

\subsubsection{Climate, Flora, and Fauna}

The Uinta Oil Shale Basin lies within the Colorado Plateau ecoregion (Woods et al. 2001). The Colorado Plateau ecoregion is characterized by a dissected tableland of benches, buttes, mesas, plateaus, salt valleys, cliffs, and canyons.

Within this ecoregion, the Uinta Basin Floor subregion includes much of Uintah County and portions of Duchesne County. This region lies in a large, arid, synclinal basin with alluvial terraces, outwash terraces, floodplains, hills, ridges, and in some areas mesas and benches alternating with lower arable land. Elevations mostly range from 4,300 to 6,400 ft, with local relief up to 1,200 ft. The basin receives a large amount of stream runoff from the adjacent mountains. The average annual precipitation is about 5 to 8 in., and the growing season is moderate to long, with 115 to 140 mean annual frost-free days. Vegetation is predominantly a saltbush-greasewood association with shadscale, Wyoming big sagebrush, fourwing saltbush, winterfat, Indian ricegrass, galleta, and needle-and-thread; black sagebrush may also be present. Streams have high levels of dissolved solids and suspended sediments; riparian areas support cottonwood trees and Russian olive, an invasive exotic tree (Woods et al. 2001).

1 An acre-foot is the volume of water that covers 1 acre $(43,560 \mathrm{ft})$ to a depth of $1 \mathrm{ft}(0.3 \mathrm{~m})$. 
The Semiarid Benchlands and Canyonlands subregion includes portions of Uintah, Duchesne, and Carbon Counties. Broad benches and mesas in alternating areas of high and low relief support grassland, shrub, and woodland vegetation types. Escarpments, hillslopes, cuestas, alluvial fans, and narrow canyons are also characteristic of this region. Elevations mostly range from 5,000 to 7,500 ft, with local relief up to 2,000 ft. A few isolated peaks of higher elevation also occur. Bare rock is common. Deep soils of fine sand over most of the region support sagebrush steppe with warm season grasses (i.e., galleta grass and blue grama) and shrubs (primarily black sagebrush, big sagebrush, blackbrush, winterfat, mormon tea, and fourwing saltbush). Shallow stony soils support piñon-juniper woodlands of two-needle piñon pine and Utah juniper. Sage parkland or mountain brush occurs on higher elevations. The average annual precipitation is about 8 to $14 \mathrm{in}$. in lower areas and 20 to $25 \mathrm{in}$. at the highest elevations. This subregion generally has a moderate to long growing season with 80 to 160 mean annual frostfree days, but less than 50 days on the highest areas. Vegetation is generally not as sparse as in the drier ecoregions.

Big game species within the study area include elk, mule deer, pronghorn, bighorn sheep, moose, American black bear, and mountain lion. Presently, the elk and mule deer are generally the most abundant, widely distributed, and sought-after big game in the region (BLM 2004c). A number of the big game species make migrations when seasonal changes reduce food availability, when movement becomes difficult (e.g., because of snowpack), or where local conditions are not suitable for calving or fawning. Established migration corridors for these species provide an important transition range between seasonal ranges and provide food for the animals during migration (Feeney et al. 2004). Water availability is a major factor affecting the distribution of big game species (BLM 2004a).

Small mammals include small game, furbearers, and nongame species. Small game species that commonly occur within the oil shale study area include black-tailed jackrabbit, desert cottontail, mountain cottontail, snowshoe hare, white-tailed jackrabbit, and yellow-bellied marmot. Common furbearers include American badger, American beaver, American marten, bobcat, common muskrat, coyote, red fox, striped skunk, and weasels. Nongame species include bats, shrews, mice, voles, chipmunks, and other rodent species.

Upland gamebirds that are native to the study area include blue grouse, ruffed grouse, greater sage-grouse, and mourning dove; introduced species include ring-necked pheasant, chukar, gray partridge, and wild turkey. All of the upland game bird species within the study area are year-round residents.

\subsection{REGIONAL PREHISTORY}

\subsubsection{Paleoindian Period (13,000 to 6,000 B.C.)}

The earliest traces of human occupation in the Utah region of interest are attributable to the Paleoindian Period. The Paleoindian Period begins slightly before 13,000 B.C. and ends around 6,000 B.C. This time span covers the late Pleistocene and the beginning of the Holocene, 
a period of great climatic changes. The recession of the glaciers allowed for wetter conditions than are evident in Utah today. Temperature swings also caused changes in the plant communities, which affected populations of Pleistocene megafauna such as mammoths, camels, horses, and sloths. During the terminal Pleistocene, these and other animals were hunted by the Native American populations, but were replaced, after extinction, by more adaptable species such as bison, deer, antelope, and jackrabbit.

The artifacts most commonly associated with Paleoindian sites in the Utah study areas are projectile points. The Clovis point is a broad, lanceolate, bifacially fluted spear point with a concave base (Agenbroad 1990), and the Folsom point is a smaller point with longer and deeper bifacial fluting. Clovis points were found in the Uinta basin $10 \mathrm{mi}$ west of Duchesne (Crouse 1954) and near Emery (Tripp 1966). Two Folsom points have been found in the Utah study regions, one in the Uinta Basin near Cedarview (Lindsay 1967) and another near the San Rafael STSA (Tripp 1967). Aside from projectile points, Paleoindian hunters used end scrapers, side scrapers, denticulate tools, burins, and bifacial knives to process the dispatched animal which, aside from the meat and hide, provided raw material for tools of bone and antler.

It is often debated whether differences in tool assemblages represent adaptations to specific environmental and resource changes. Spangler (2002:219-224) notes a number of Paleoindian complexes in the Uinta Basin after 10,000 years ago, including the Clovis and Folsom complexes. Evidence from assemblages considered part of the Plano Complex suggests an increased emphasis on plant collecting (Frison 1991; Irwin 1971; Jennings 1978), hunting of smaller animals, and an adaptation to hotter and drier conditions (Irwin-Williams and Haynes 1970). Sixteen Paleoindian sites attributable to the Plano, Agate Basin, Hell Gap, Alberta, Cody, Scottsbluff, Lake Mohave, Plainview, and Angostura Complexes have been found in the Uinta Basin (Spangler 2002:223). These complexes are defined primarily by a variety of diagnostic, nonfluted projectile points that have limited geographic distributions in Utah and surrounding regions. A Lake Mohave point, indicative of one of the late Paleoindian complexes, was recovered from a site in the San Rafael STSA (Tipps 1988:43).

\subsubsection{Early Archaic (6,000 to 3,000 B.C.)}

The Archaic can be characterized as a period of mobile bands seasonally exploiting a wide variety of plant animal species in different ecological zones (Spangler 2002:227). During the Archaic, the climate became drier than in the Pleistocene. Megafauna went extinct and were replaced by bison, deer, antelope, sheep, and other small mammals. Hunting was augmented by the procurement and processing of edible wild plants. Evidence of plant processing (grinding stones) and Early Archaic architectural forms (semisubterranean pit-houses with interior features) exists in archaeological contexts outside of the oil shale and tar sands study areas.

The Early Archaic dates from 6,000 to 3,000 B.C. In the Uinta Basin and the southern STSAs, the period is represented by projectile points and other lithic tools. Early Archaic projectile points include the Pinto Series, Elko Series, Humboldt, Northern side-notched points, Hawken, and Sudden Side-notched. These have been documented as surface finds, and, in a few cases, from cave excavations near the San Rafael STSA (Spangler 2002:246-250; 
Tipps 1988:42). These Early Archaic points appear to be the tips of thrusting spears rather than dart tips thrown using atlatls. Styles generally show cultural affinities to types defined for the Great Basin, rather than the High Plains.

There is little archaeological evidence showing cultural continuity from the Paleoindian Period through the Archaic in the Uinta Basin. It has been suggested that the lack of sites of Early Archaic age reflects the reduction of occupation intensity or a shift to base camps sited in other locations, rather than the complete abandonment of a geographic area. Changes in site location and density may indicate adaptation to shifting resource availability precipitated by climatic changes (Spangler 2002:250). The desert conditions of the Middle Holocene may have been unfavorable to the populations foraging in the Uinta Basin, as in other desert basins west of the Rocky Mountains.

\subsubsection{Middle Archaic (3,000 to 500 B.C.)}

The Middle Archaic (3,000 to 500 B.C.) is a period characterized by an increase of human populations during a time of improving climatic conditions. After 2,500 B.C., the climate of the late Holocene in the Intermountain West was generally cooler and moister than during the preceding early and middle Holocene, although conditions were often punctuated by alternating and significant climatic fluctuations. Large and small game were still hunted, and the numerous plant species that flourished in the wetter climate were collected and processed. The general climatic amelioration led to increased population levels throughout the North American West (Spangler 2002:252).

Resource exploitation strategies changed little from the Early Archaic in the Uinta Basin and southern STSAs, except for the appearance of lanceolate points. This sort of weaponry was dominated by the McKean Complex, which had its origins in the northwestern Plains. Elko Series points, with their Great Basin affinities, were still found in the Uinta Basin, as were the San Rafael side-notched and Gypsum point types from the northern Colorado plateau. Five Middle Archaic sites were found at the Circle Cliffs STSA, four sites at the San Rafael Swell STSA, and two at the White Canyon STSA (Tipps 1988:42). A few of these sites have McKean lanceolate and Hawken points from the Plains.

\subsubsection{Late Archaic (500 B.C. to 550 A.D.)}

One hundred and sixty-six radiocarbon dates from 80 Late Archaic sites suggest a continued and increasingly intensive occupation of the greater Uinta Basin during this period of changing technologies and subsistence strategies (Spangler 2002:284). The Late Archaic extends from 500 B.C. to 550 A.D. Archaic hunter-gatherer strategies and settlement patterns continued to focus on the procurement of plant and animal resources, although sedentism increased as maize horticulture was introduced into localized economic strategies.

On the High Plains, hunting strategies changed radically when the bow and arrow were introduced. Arrow points were easier to manufacture than spear points or darts; bows propelled 
arrows at a greater velocity and with greater range, allowing greater stealth while hunting and greater penetration of the food prey (Frison 1991:211-212). Bow and arrow technology had become established in the study area by about 200 A.D. (Spangler 2002:305), although it did not replace the use of atlatls and spears completely as a hunting strategy until later prehistoric periods. A few specimens of an early arrow point type called Rose Spring have been found in Uinta Basin Late Archaic sites (McKibbin 1992:422; Truesdale 1989, 1990), and three were found in the Circle Cliffs STSA (Tipps 1988: 86). Numerous Late Archaic spear points have been found in the Uinta Basin region and in the tar sands areas to the south.

Maize horticulture augmented the wild plant component of the Late Archaic diet. Maize appears in the archaeological record in the Uinta Basin circa 200 A.D. (Coltrain 1994), roughly contemporaneous with the establishment of bow and arrow hunting technology in the region. Isotope analysis of skeletal materials at Steinaker Reservoir, near the Asphalt Ridge STSA, indicates that prehistoric diets were dependant on maize but supplemented by wild resources (Coltrain 1994:7). A corncob was recovered from a masonry granary at a site near the Argyle Canyon STSA and provided a calibrated date of 34 A.D. (Spangler 1993; Thompson 1993).

It is believed that maize horticulture required a commitment to sedentism and made mobile foraging difficult. Seasonal sedentism related to horticulture would still allow for foraging and hunting (Coltrain 1994). Increased sedentism throughout the Late Archaic required residential architectural forms that left semisubterranean oval or circular dwelling depressions, often with storage pits. Permanent architecture, some with adobe and stone masonry and postholes, has been found in the greater Uinta Basin Region, where it was attributed to the very end of the Late Archaic (Truesdale 1990).

\subsubsection{Formative Era (A.D. 550 to 1,300)}

Morss (1931) first applied the term Fremont to describe cultures north of the Colorado River that displayed certain Anasazi traits but remained distinctively different. A great deal of variation existed among groups designated Fremont. Wormington (1955) distinguished between people of the northern Colorado Plateau (Fremont culture) and those west of the Wasatch Mountains (Puebloid culture). Jennings (1956) applied the term "Sevier Fremont" to people of the northern Colorado Plateau and "Fremont" to those east of the Wasatch Mountains. Marwitt (1970) defined five regional Fremont variants; the Uinta, San Rafael, Great Salt Lake, Sevier, and Parowan. The term Fremont has become a catch-all. Spangler (2002) cited Ambler (1970) as stating that the use of trait lists to define the Fremont is "so generalized as to be useless" and cited Madsen (1979:735) as suggesting that "Fremont" be used as "a label for the sum of the variation among the differentially horticultural, variably sedentary, and perhaps separately derived populations located roughly north of the Colorado and Virgin Rivers." In an overview, Spangler 2002:320) stated that "traditional definitions of the Fremont are inadequate to describe Formative manifestations in the Uinta Basin or explain cultural change in that area."

Hunter-gatherers in eastern Utah and Western Colorado started acquiring maize during the late Archaic. After A.D. 550, some groups attained increasing sedentism based on horticulture, used pottery, created rock art, modeled clay figurines, wore moccasins rather than 
sandals, and made distinctive coiled basketry. The main crop was corn, though beans and squash were grown. Bow and arrow were used. Subsistence among groups ranged from full farming to full foraging, with combinations of focus varying between areas and within groups through time (Madsen and Simms 1998). The Fremont Tradition, as the term is generally applied, includes both nomadic and sedentary people sharing the subject area and defined cultural characteristics during the time when sedentary horticulture was practiced (Grady 1984; Jennings 1978; Marwitt 1986). Some describe the culture of nomadic groups in Colorado (Reed and Metcalf 1999) and the westernmost Uinta Basin river valleys as belonging to an Aspen Tradition (Spangler 2002).

Marwitt (1970) defined the Uinta Fremont as a local variant confined to the Uinta Basin and assigned a period of A.D. 650 to 950. Archaeological characteristics include a dominance of Uinta-Gray pottery, a distinctive metate, large-shouldered bifaces, and two-handled widemouthed pots. Figurines and and village storage pits were generally absent. Projectile points are not unique to the basin. Shallow, saucer-shaped pit-houses or surface structures with randomly placed postholes and adobe-rimmed or unrimmed off-center fire pits occur in groups of about five or less. Dwelling sites were often located on butte tops, knolls, or slopes above floodplains. Small dwelling sites and an absence of storage structures near dwellings suggest short and possibly seasonal occupations and a limited emphasis upon horticulture relative to nearby variants of the Freemont (Marwitt 1970; Hurlbett 1976). Rock art as found in the AshleyDry Fork drainage and Nine Mile Canyon area is world renowned

Several phase sequences have been proposed for the Uinta Basin. Marwitt (1970) suggested a two-phase sequence that, though supporting chronometric data were unavailable, has been adopted by others. The Cub Creek Phase (A.D. 650 to 800) was characterized by a predominance of semisubterranean pit-houses and a lack of surface structures and coursed-adobe construction. Tradeware was absent and Uinta Gray pottery was used exclusively. Artifacts included net sinkers, stone balls, bone and stone pendants and gaming pieces. The Surface and semisubterranean masonry and coursed-adobe residential structures mark the Whiterocks Phase (A.D. 800 to 950). Circular and ovoid structures continued, and houses with square and rectangular plans appear. Uinta gray pottery continued to dominate, but tradeware appeared.

Spangler (2002) combines his (1995) temporal scheme with a nomenclature suggested by Talbot and Richens (1999) to arrive at a scheme dividing the Uinta Basin Formative into the Early (A.D. 1 to 550), Middle (A.D. 550 to 1050) and Late (A.D. 1050 to 1300) Agricultural Periods. During the Early Agricultural Period (Late Archaic), cultivation started, but the focus remained on hunting and gathering. During the Middle Agricultural Period, ceramics were introduced and sedentism became common on bottomlands. Farming declined and disappeared during the Late Agricultural Period.

Most Uinta-Fremont sites date to the Middle Agricultural Period, A.D. 550 to 1050. During this period, people adapting to different environments in various ways lacked homogeneity, and sites reflected predominantly horticultural, exclusively foraging and mixed lifestyles. Using carbon dates, Spangler has demonstrated shifts in settlement patterns in the Uinta Basin during this time. Before A.D. 700, small farmsteads were situated on alluvial fans and in foothills associated with permanent streams. Houses were commonly circular 
semisubterranean pit-houses with central posts, adobe-rimmed hearths and compacted soil floors. After A.D. 700, isolated houses and hamlets were also situated on buttes, ridges, and valley floors. Increasing numbers of square and rectangular pit structures were used, as were surface structures, which included masonry and puddled-adobe construction. Prepared floors were common. Most houses were permanent or semipermanent styles. Carbon-14 dates indicate that the number of foraging sites increased along with the increase in sedentary sites during the Middle Agricultural Period. The foraging sites lacked residential architecture or storage structures but contained ceramics and maize. From A.D. 1050 to 1300, the lower elevations of the basin were abandoned, while Fremont traits persisted in upper river valleys (Spangler 2002).

\subsubsection{Ancestral Puebloan (Anasazi)}

The discussion of the "Formative" period in the study area includes another well-known cultural manifestation that appears in the southern portion of Utah following the Desert Archaic period. A portion of the study area lies within the Ancestral Puebloan culture area. The term "Anasazi" has traditionally been applied to the Ancestral Puebloan, and it is this term that has been widely used to identify the agricultural, pueblo-dwelling populations that are defined by their distinct ceramic styles and architecture. The Ancestral Puebloan, as the name implies, are recognized as the ancestors to the modern Puebloan groups currently living throughout the Southwest.

The Ancestral Puebloan archaeological sites are abundant throughout the Four Corners area of southeastern Utah, southwestern Colorado, northwestern New Mexico, and northeastern Arizona; and also in southwestern Utah and northwestern Arizona. The STSAs of White Canyon and Circle Cliffs in southern Utah were once home to Ancestral Puebloan populations known as the Mesa Verde (White Canyon) and Kayenta Anasazi (Circle Cliffs), variants of the Ancestral Puebloan culture (Jennings 1978).

Arising out of the local Archaic cultures of the region, the various stages of cultural development in Puebloan prehistory are often thought to have been defined largely by distinct technological changes or changes in the ceramic sequences. However, it has been argued that these cultural periods were not just arbitrarily defined on the basis of ceramic styles, but actually correlate to climatic shifts and the onset of regional droughts that affected the prehistoric Puebloan populations (Lipe 1980). From about A.D. 1 to 1300, the Ancestral Puebloan lived throughout the region, although the classic time period is generally thought to be A.D. 500 to 1300. It is during this time period that villages and hamlets, some of great size, dotted the canyons and upland landscape.

Although it is theorized that early experimentation with gardening began during the late phases of the Desert Archaic in this area of Utah, the prehistoric Puebloans relied much more heavily on agriculture than their Archaic predecessors. While hunting and the gathering of wild plant foods were sustained throughout the Formative, it appears that the Ancestral Puebloan had developed into a subsistence reliant on farming, at least by A.D. 500 to 700. Maize, squash, and beans, along with several weedy plant species such as pigweed, beeweed, and sunflower, were cultivated, and seemingly on a grander scale than that of their Fremont counterparts to the north 
(Jennings 1978). Domesticated turkeys were also raised during the time period after A.D. 400. Overall, the Formative is a time of increased populations, permanent settlements, a proliferation of arts and crafts, and more elaborate ritual ceremonialism.

The Ancestral Puebloan cultural chronology was first developed out of the 1927 Pecos Conference and was intended to be applied to the entire Southwest. The chronology divides the Puebloan prehistory as a whole into Basketmaker (II and III) and Pueblo (I-V) time periods. The following paragraphs are intended to provide only a broad description of some of the major characteristics of each time period. Cultural variation is shown from site to site and will not be included in this overview. Decades of research have been conducted on archaeological sites from all Ancestral Puebloan time periods, resulting in volumes of literature on too grand of a scale to summarize here.

The chronology included the time period known as "Basketmaker I" (pre-A.D. 1), which has since been replaced with the Desert Archaic tradition. The Basketmaker II period (A.D. 1 to 500) sites reveal much of the same as in the Archaic, but also exhibit some major technological changes from what is generally applied to the Archaic lifestyle. It appears to be the transitional phase between the Desert Archaic and the later Puebloan cultural manifestations throughout the region. Much of the Basketmaker II data were derived from cave sites in the Four Corners region (Jennings 1978). Widely scattered, permanent villages also appear during this time period. In southeastern Utah, villages were fairly large base camps with scattered houses near natural springs. Both semisubterranean pit-houses and standing aboveground structures appear at village sites. Ceramics appear during this period as brownwares (Lipe 1980). In general, Ancestral Puebloan pottery was produced by coiling and scraping and was fired in an oxygen-poor atmosphere that gave it its gray to white color (Jennings 1978). In addition, in southeastern Utah, oxidized red and orange was produced. Basketmaker II sites also revealed the use of the atlatl, but technologically, the time period is known for the intricate coiled basketry with red and black ornament.

The Basketmaker III (A.D. 500 to 700) period is characterized by an intensified use of farming. A shift in settlement patterns, and likely in adaptation, marks this period in the Ancestral Puebloan sites throughout the region. Sites tend to be located near well-watered soils in alluvial valleys and in the uplands. Agriculture becomes prominent and villages of 50 or more structures are common. Although some researchers indicate that the cultivation of beans and domestication of turkey first occurred during the Basketmaker II period, it is in the Basketmaker III period that these additions to the subsistence strategy become recognized. Intricate coiled baskets and twined mats are still plentiful in the archaeological record, but the strong addition of ceramics appears as well. Ceramic styles include the appearance of plain graywares and graywares exhibiting black designs. By the end of this period, the appearance of distinctive red-on-orange pottery appears in southeastern Utah. It is during this period that the ceremonial structure, the kiva, appears at habitation sites. A uniquely Ancestral Puebloan trait, the subterranean structure appears to have been derived from the pit-house structure, but its use shifted gradually from residential to ceremonial (Cordell 1997).

While the Pueblo I period (A.D. 700 to 900) shows a continued population increase in the area, the sites exhibit less uniformity than Basketmaker III sites in the region. The sites appear to 
be in higher elevations or near large alluvial valleys. They range from small hamlets to larger villages. The sites contain both aboveground structures and pit-houses; however, the use of kivas for ceremonial purposes and the appearance of the great kiva are more prominent during this time period. The aboveground structures are constructed mainly of jacal as in the earlier Basketmaker time periods, but masonry structures begin to appear as well. The domestication of cotton is also documented in some regions (Lipe 1980).

The Pueblo II period (A.D. 900 to 1100) is often referred to as the period of Chacoan florescence, where archaeological and ethnographic evidence suggest that the communities built in Chaco Canyon in northwestern New Mexico became an economic and spiritual epicenter of Ancestral Puebloan existence. Its influence was far-reaching throughout the Four Corners area (Cordell 1995). Villages within Chaco Canyon were characterized by multistoried great houses (some up to four stories) containing hundreds of rooms and numerous kivas. Dotted around these villages were "unit" pueblos, made up of a residence with its own "family" kiva. Evidence for roads that radiated out from Chaco and connected to outlier sites, some of which are up to $118 \mathrm{mi}$ away, has been documented. There are many theories applied to the Chaco phenomenon. Chaco appeared to have served as a redistribution center for food, goods, and exotic trade items as well as a ceremonial center (Lipe 1980).

The early part of the Pueblo III period (A.D. 1100 to 1300) continues to see large, multistoried pueblos dominating in this region. However, it appears that there was a movement into larger more densely populated communities as well as a movement from open locations to shelters and ledges in canyon walls. Many of these pueblos were difficult to reach and their locations appear to be for defensive purposes. Other defensive features appear in some pueblos during this time period, such as loopholes in walls flanking entries, walls blocking access to ledges, and the construction of towers (Jennings 1978). Some of the towers contain tunnels that lead to kivas, perhaps suggesting a ceremonial function in addition to a defensive function.

There is an increase in craft specialization and artistic production in the early phases of the Pueblo III period. In some areas, the ceramics reached a technical and artistic peak. This was not to last, as the later part of this period saw a decline of the population of the region. It is in the later portion of this time period that the Pueblo sites in southern Utah were abandoned. It would be naïve to assume that the decline of Ancestral Puebloan occupation of the region and of the Colorado Plateau in general was due solely to draught and/or climatic variability. Still, it was more than likely a large contributing factor to a society dependent upon farming in an arid environment. Populations appeared to have moved south and southeast, and were virtually gone by A.D. 1300. The Pueblo IV period (A.D. 1300 to 1600) is indicative of this southward migration.

Archaeological evidence suggests that around 1400 to 1500 A.D., the Navajo moved into southern Utah. Navajo oral history places their arrival in the Southwest somewhat earlier (Roessel 1983). From the archaeological record and ethnographic evidence, it appears that the Navajo did not encounter the Ancestral Puebloans when they arrived. The archaeological evidence is quite slim, however, for an early historic Navajo presence within the Circle Cliffs, White Canyon, and Tar Sands Triangle STSAs, which are located closest to Navajo traditional lands on the southern edge of Utah. 
Having moved southward out of Utah by A.D. 1300, Ancestral Puebloan groups are thought by some to have evolved into existing Puebloan cultures of Arizona and New Mexico. Hopi oral tradition describes a migration from the north. The Hopi claim cultural affiliation with Paleoindian, Archaic, and Fremont people who inhabited Utah (Ferguson 1997, 2003). Such affiliation is still a topic of debate among archaeologists, however.

\subsubsection{Shoshonean Era (A.D. 1300 to 1850)}

Horticulture and sedentism waned at different times in different Fremont subareas and disappeared throughout the area by about A.D. 1300. The succeeding period of exclusive hunting-gathering subsistence has been called the Shoshonean (or Numic) Era. While the effects of climatic stress and/or outsiders are among proposed reasons for the return shift to hunting and gathering, that shift occurred in the Uinta Basin at a time (A.D. 1050) when climatic conditions should have been favorable for horticulture. Material markers include Desert side-notched projectile points, Shoshonean pottery, and knives. The era is poorly known in the Uinta Basin, and Shoshonean and Fremont diagnostics are sometimes found in association with each other. (Spangler 2002). Pedestrian foraging persisted until the time of European impact.

\subsection{REGIONAL ETHNOHISTORY}

Three linguistically and culturally related tribes traditionally occupied territory within or adjacent to the Utah portion of the study area. Ute territory covered most of the study area, while the Shoshone bordered to the north and Southern Paiute bordered to the south. All three groups spoke a Numic language, but only the Utes and the Southern Paiutes spoke dialects that were mutually comprehensible. The tribes subsisted on the hunting and gathering of species that varied by locale. Temporary or portable housing was used during the seasonal rounds. With the introduction of the horse, some Ute and Shoshone bands adopted focused buffalo hunting, longpole tepee housing, and other characteristics of the Plains Culture (Callaway et al. 1986; Steward 1997).

Traditional Ute territory extended through most of present-day Utah and Colorado and into northernmost New Mexico. Five bands - the Pah Vant, San Pitch, Tupanawach, Cumumba, Unitaats and Sheberetch-appear to have occupied territories within the Utah portion of the oil shale and tar sands study area. The Utes lived in family groups and utilized pack dogs and dogtravois during seasonal migrations between desert and mountain resource areas. Portable shelters, such as hide tepees, or shelters made of brush or other disposable materials were used. Family groups lived closer together in winter and joined together at certain times of the year for special activities (Duncan 2000; Conetah 1982).

Traditional Shoshone territory included large areas within present-day Idaho, central Nevada, western Wyoming, and northwestern Utah. Prior to the introduction of horses, huntinggathering Shoshone lived in conical houses made of brush, grass, or woven branches. Shoshone in northwestern Utah relied on wild plant foods, importantly pinion nuts, and on fish, small game, and larger game such as antelope, deer, and mountain sheep. The kammitakka (jackrabbit- 
eaters) sometimes traveled into northern Utah to gather pine nuts or to winter over. The Shoshone remained hunters and gathers and did not acquire horses until the 1850s. The Shoshone who were buffalo hunters formed large and militaristic bands, but seasonally exploited mountain resources in northern Utah (Murphy and Murphy 1986).

Traditional Southern Paiute territory covered parts of present-day southern Utah, southern Nevada extending slightly into California, and northern Arizona. The Southern Paiute were hunters and gatherers who migrated within band territories. They lived in caves or wickiups during winter, and rectangular shades or circular wind shelters made of brush at other times. (Kelly and Fowler 1986). Teepees were adapted from the Utes after the 1850s (Tom and Holt 2000).

\subsection{REGIONAL HISTORY}

\subsubsection{Exploration and the Fur Trade}

The first non-native peoples to enter the Uinta Basin were the members of the Dominguez-Escalante Expedition (Spangler 2002:477-478). Fray Francisco Atanasio Dominguez and Fray Silvestre Velez de Escalante passed through northeastern Utah in 1776 during their search for a northern route between the Spanish settlement in Santa Fe, New Mexico, and a newly established garrison at Monterey on the Pacific Coast. Escalante's journal of the expedition provides a wealth of ethnographic data regarding the native inhabitants of the region during the mid-eighteenth century. The journal also documents the route of the expedition. This early penetration of the Uinta Basin left scant archaeological evidence, although some unverified reports still circulate regarding isolated finds of Spanish artifacts.

Euroamerican fur trappers first entered the Uinta Basin in the early $1800 \mathrm{~s}$ (Spangler 2002:480-485). Isolated scrawls on rock faces indicate dates as early as 1818, but the year 1824 is generally considered the opening of the Uinta Basin fur trade, with three separate parties reported in the region at that time. In 1825, William Ashley and a party of trappers from the Rocky Mountain Fur Company entered the Uinta Basin from the north, floating down the Green River. Ashley acquired horses from the Utes and returned to Wyoming, where he established the system of annual trappers' rendezvous. At that time, trappers from Canada (the Hudson Bay Company) and from Taos, New Mexico, were also operating in the Uinta Basin. In 1828, the Reed Trading Post was established at the confluence of the Whiterocks and Uinta Rivers. This post was later acquired by Antoine Robidoux, who established a small fur trading empire that dominated economic activity in the Uinta Basin through the 1830s and early 1840s. Robidoux built "Fort Uinta" and oversaw a brisk trade undertaken by the 20 trappers in his employ, in addition to other fur trappers and Native Americans. Fort Uinta was attacked and burned in 1844. It was never rebuilt, as the fur trade was already in decline. A handful of other trading posts or "forts" were established in the Uinta Basin by Robidoux's competitors. These include Fort Davy Crockett, which is the only such post that has been definitively relocated and subjected to professional archeological excavations. Numerous rock inscriptions found in the 
basin have been attributed to the trappers who roamed this region in the early days. The scant archaeological evidence of the fur trade era constitutes invaluable historic cultural resources.

Unlike other parts of the American West, the fur trapping era in the Uinta Basin was not followed up by settlement, but by an extended period of exploration (Spangler 2002:485-490). This was no doubt because of the region's remote location and arid climate, factors that inhibited the influx of settlers - even those who were simply passing through. John Fremont led expeditions through the basin in 1844 and 1845. In 1853 to 1854, three separate expeditions passed through the Uinta Basin, ostensibly in search of viable transcontinental railroad routes. Little physical evidence of these transitory expeditions remains. John Wesley Powell led expeditions down the Green and Colorado Rivers through the Uinta Basin in 1869 and 1871. Clarence King led an expedition through the Uinta Mountains in 1869 to 1870. These expeditions produced important scientific and cartographic information for the region, but left little trace on the landscape.

\subsubsection{Farming and Ranching}

Permanent settlement in the Uinta Basin proper was slow to materialize (Spangler 2002:495-500). After the disappearance of the early trappers, the arid desert basin did not see any European settlements until the establishment of an Indian agency on the Uinta and Ouray Reservations beginning in the late 1860s. A few small cattle ranchers moved into the region beginning in the mid-1870s, but these operations were centered on the well-watered foothills of the Uinta Mountains north of the basin. At about the same time, the first handful of Mormon colonists settled near Jensen and Vernal on the Green River. These farmers, and other homesteaders who followed, soon found that irrigation was an absolute necessity for successful agriculture in the region. Networks of irrigation canals and reservoirs were developed through the late nineteenth and early twentieth centuries. Many of these are still functioning while others are considered historical in nature. Most evidence of irrigation is restricted to the arable lands located between Duchesne and Jensen and is located outside of the Uinta Basin proper. The first few cattle ranching operations in the Uinta Basin were started in the 1890s (Spangler 2002:507-508), but these are considered quite rare. Sheep raising became a large component of the livestock industry beginning in the early twentieth century (Larralde and Chandler 1981:88). Much of the basin's wool production was shipped out of Watson on the Uintah Railway. Remains of abandoned homesteader cabins dating from 1905 to 1920 occur throughout the region, and some of these may occur in the basin.

\subsubsection{Mining}

Gilsonite was discovered in the Uinta Basin in the late 1800s (Spangler 2002: 500-501). The commercial potential of the mineral was recognized by entrepreneur Samuel H. Gilson, who organized the first company to extract deposits in 1888. Gilsonite was mined in the Uinta Basin and hauled, at first, by wagon through Myton to Price, Utah. After additional gilsonite mining operations were opened, a narrow-gauge railway was built into the basin in 1904. The Uintah Railway extended from the mine at Dragon southeast to Mack, Colorado, where it linked with 
the main line of the Denver \& Rio Grande Railroad. The town of Dragon Junction sprang up along this rail line, which was extended to Watson in 1911. Freight service was extended by wagon road from the railhead through Bonanza, across the Green River at Ouray, and on to the settlements at Vernal and Fort Duchesne. Gilsonite mining continued through the late 1930s when modern paved roads able to support large haul trucks reached the area. The Uintah Railway folded and the tracks were torn up in 1939. Active mining operations shifted north to the company town of Bonanza. The Gilsonite-related mining towns of Dragon Junction, Rainbow, and Watson were abandoned and are now ghost towns.

Oil and gas production met with very limited success in the Uinta Basin (Spangler 2002: 501-502). The first oil well was drilled on the East Tavaputs Plateau near the Uintah-Grand County line in 1900, but no oil was produced. More than 40 other wells were sunk in Uintah County between 1900 and 1940, but only a small amount of oil was produced. The tarry substance encountered in these wells was too viscous to be pumped. Natural gas had been discovered near Jenson in 1925. It was piped to Vernal for local consumption, but the supply was exhausted by 1941. A new wave of oil and gas exploration took place after World War II, which resulted in the discovery of major oil deposits on the northern edge of the basin around Vernal.

The first attempt at oil shale exploitation took place in 1917 by the Ute Oil Company (Spangler 2002:502). Construction began on a tramway and processing plant located near Watson. Processing was supposed to extract $90 \%$ of the oil contained in the pulverized oil shale to produce an average of 54 gal of oil per ton of shale. The effort was abandoned in 1922. Interest in oil shale production rebounded when oil prices peaked in the 1970s, but interest faded again as oil prices declined again after 1980 .

\subsection{PREVIOUS RESEARCH}

\subsubsection{Uinta Basin}

\subsubsection{Surveys and Overviews}

People had noted ruins and other archaeological manifestations in the Uinta Basin for many years before trained archaeologists came to the region (Spangler 2002:15-24). Escalante's journal account from 1776 mentions pottery scatters, rock paintings, and the ruins of a pueblo seen on the Duchesne River. John Powell's 1869 and 1871 expeditions encountered rock cairns, graves, grinding stones, pictographs, and the ruins of dry-laid stone walls. Through the last part of the nineteenth century and the early twentieth century, several academics and antiquariansnone with any training in anthropology or archaeology—collected artifacts and "surveyed" parts of the basin for ruins and rock art.

The first trained researchers began working in the Uinta Basin in the late 1920s (Spangler 2002:25-42). The Claflin-Emerson Expedition, sponsored by Harvard's Peabody Museum, roamed northeastern Utah from 1927 to 1931. They documented ruins and recorded 
cave, rockshelter, and rock art sites. They partially excavated some of these sites. From 1931 to 1935, amateur archaeologist Frank Beckwith recorded and photographed numerous rock art panels throughout the basin. From 1930 to 1934, Albert Reagan, a retired teacher from Ouray, worked in the basin excavating earth lodges and stone houses, and documenting camp sites, rock art, cairns, ruins, ancient irrigation structures and granaries, and cave sites. In 1931, Dr. Julian Steward, one of the most influential and respected anthropologists of his generation, worked briefly in the basin excavating three pit-houses and a rock-walled structure. In 1934, Professor Leonard Leh from the University of Colorado explored the country from the West Tavaputs Plateau eastward to the Green River, recording storage structures on the cliffs. Also in 1934, Alfred Gaumer excavated several rockshelters, caves, and a ruin in Desolation Canyon. An expedition from the Utah State Museum Association ventured into the Uinta Basin in 1934 as well. They recorded rock art near Vernal and Jensen, and in Nine Mile Canyon. In 1936, John Gillin from the University of Utah undertook some of the most professional archaeological work ever conducted in the basin. Gillin excavated pit-houses and defensive structures near Ellis Ranch in Nine Mile Canyon.

After 1940, archaeologists working in the Great Basin began ordering and arranging much of their data. Pottery seriation, improved stratigraphic excavation techniques, the development of a regional dendrochronology (tree-ring dating) sequence, and the advent of radiocarbon-dating technology enabled chronologies and prehistoric cultural sequences to be established. Work in northeastern Utah during the period from 1940 to 1960 was concentrated at two localities in Nine Mile Canyon and on the East Tavaputs Plateau (Spangler 2002:44-58). Through the 1940s, Marie Wormington from the Denver Museum of Natural History excavated the ruins of several dry-laid stone structures and documented rock art sites on the East Tavaputs Plateau. Based in part upon this work, she developed extensive trait lists for five geographic divisions of the Fremont culture. From 1954 to 1955, the Utah Statewide Archaeological Survey came to the Uinta Basin with the express purpose of systematically documenting the extent of the Fremont culture in the region. Many open sites, rockshelters, and rock art were visited. Most were surface-collected, and a few were subjected to limited test excavations. The survey covered stream valleys in the foothills of the Uinta Mountains, the lower White River valley, sections of Willow and Hill Creeks, and Range Creek Canyon.

By 1960, institutional archaeological work in the Uinta Basin exhibited a greater degree of professionalism and an improved orientation toward specific research questions (Spangler 2002:62-79). Academic archaeologists from the University of Utah conducted a series of site excavations in the Uinta Basin over the next two decades. In 1961 to 1962, crews excavated three small high-altitude sites in the upper reaches of Hill Creek Canyon on the East Tavaputs Plateau. In 1963, they excavated a Middle-Late Archaic component in Thorne Cave near Jensen. In 1966, they excavated the remains of domestic structures at five sites in the foothills of the Uinta Mountains, including the Goodrich site, the Gilbert site, Flattop Butte, Felter Hill, and Whiterocks Village. Archaeologists from the University of Colorado were working in northeastern Utah at around the same time. In 1964, they excavated the Caldwell Village site near LaPoint, Utah. Caldwell is the most complex Fremont site investigated in the Uinta Basin, with the remains of nearly two dozen dwellings, numerous pits and hearths, human and dog burials, and at least one prehistoric irrigation ditch. The site was apparently a long-term habitation site documenting a continuous Fremont presence for some 800 years. Comprehensive 
surveys of Uinta Basin rock art were conducted in 1970 to 1971 by Polly Schaafsma for the University of Utah and the Peabody Museum. A subsequent rock art survey along a section of Nine Mile Canyon was conducted by students from Brigham Young University (BYU) in 1974 to 1975 . An even more comprehensive rock art study was undertaken in the early 1980s by Kenneth Castleton of the University of Utah.

By the late 1980s, institutional work in the Uinta Basin lapsed into small-scale surveys for the most part (Spangler 2002:86-97). From 1989 to 1992, certified amateur archaeologists with the Utah Statewide Archaeological Society intensively surveyed sections of Nine Mile Canyon, recording more than 250 prehistoric and historic sites. Concurrent with that work, BYU conducted field schools in Nine Mile Canyon in 1989 to 1891. The BYU team recorded 178 sites and excavated 7 small structures.

In the late 1970s, CRM began to be effectively implemented by federal agencies, and this resulted in some of the first projects conducted by contract archaeologists in the Uinta Basin (Spangler 2002:104-106). Over the last half-century, CRM archaeology has been conducted for water reclamation projects and for various oil, gas, and oil shale developments in the region (see Figure 3-1).

Survey work related to the Central Utah Project, a massive series of water diversions, was conducted by the University of Utah from 1959 through the late 1980s (Spangler 2002:118-130). A survey around Steinaker Reservoir, north of Vernal, was conducted in 1959 and resulted in the discovery of 18 sites, 4 of which were test-excavated. Over the next 35 years, additional work was performed after the reservoir was completed and shoreline erosion began exposing human burials, fire pits, and the remains of pit-houses. In 1982, another 350 acres at Steinaker was surveyed by Mesa Corporation, which found another 13 sites, 4 of which were later testexcavated by BYU archaeologists. Despite the piecemeal progress of these investigations (typical of CRM work), the wealth of data generated at Steinaker Reservoir has helped redefine regional Late Archaic and Formative adaptations.

Survey at Red Fleet Reservoir, also north of Vernal, was undertaken in 1973 (Spangler 2002:130-131). That survey located four sites, one of which was test-excavated. Another of the four is 42UN416, a complex rock art panel now listed on the NRHP. Another of these sites - a mummified infant burial located in a dry alcove-was later vandalized. The subsequent criminal investigation in 1991 led to a detailed analysis of the human remains and associated materials.

Surveys for other parts of the Central Utah Project and other water diversion projects found relatively few sites (Spangler 2002:131-138). Between 1973 and 1983, surveys were conducted for proposed reservoirs, aqueducts, and related facilities near Whiterocks and Neola westward to Mountain Home, Duchesne, and Fruitland. These surveys encompassed more than 25,000 acres and more than 140 mi of linear transects. Remarkably, despite the extensive areas covered, very few sites were found. Of the 110 prehistoric and 185 historic sites reported, only 11 of the prehistoric sites were test-excavated. None were found to be significant. 


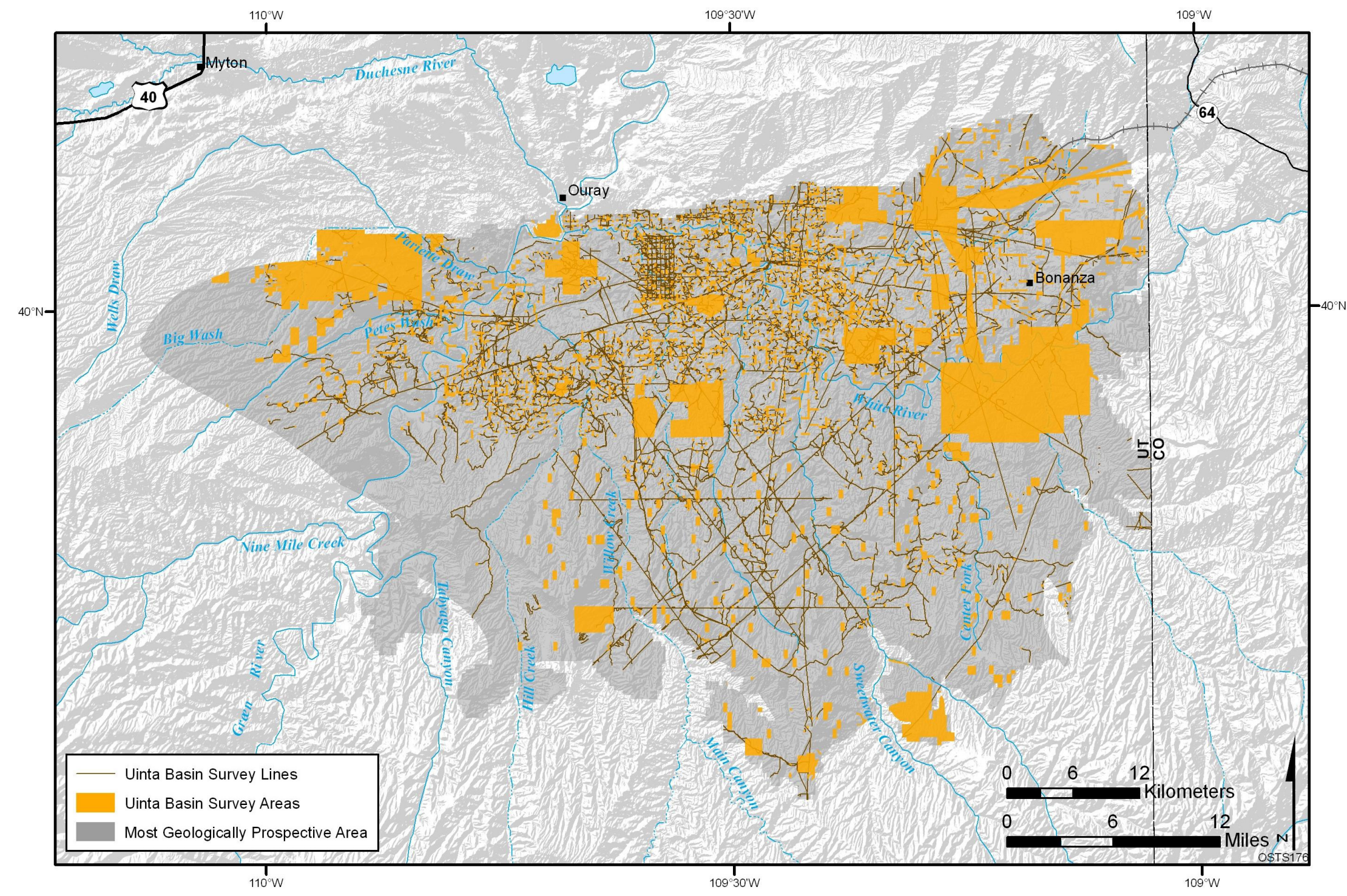

FIGURE 3-1 Cultural Resource Surveys in the Uinta Basin, Northeastern Utah 
The BLM surveyed 480 acres of the Pariette STSA near Myton in 1984 (Spangler 2002:137). Eleven prehistoric sites and an historic dump were recorded. Most of the sites were found clustered within a single 40 -acre portion of the area.

Surveys were undertaken in 1975 for proposed oil shale development on $42.5 \mathrm{mi}^{2}$ along the White River above Asphalt Wash (Berry and Berry 1975; Spangler 2002:139-141). Six historic and 31 prehistoric sites were found in that area. The prehistoric sites consisted of rockshelters, open camp sites, and a rock art panel. Ninety percent of these sites were located on the floodplain and terraces of the White River or its tributaries. Nearly all of the rockshelters had been vandalized. Several of the open sites were later test-excavated. Some were found to have little content, but others contained deposits buried in up to $2 \mathrm{~m}$ of colluvium. The historic sites consisted mostly of small log dwellings and corrals associated with ranching and gilsonite mining. None were considered historically significant except for the Ignacio Stage Stop, which was nominated to the NRHP.

Class II sampling surveys were undertaken throughout the Uinta Basin region beginning in 1978 (Spangler 2002:145-153). These surveys posited models of prehistoric site locations in relation to physiographic and vegetational variables. The models were then tested by surveys that sampled portions of the large areas under consideration. These areas were defined on the basis of proposed oil shale or coal development. The Natural Buttes survey covered a stratified $10 \%$ sample of 34,720 acres on the lower White River in 1978 (Hauck et al. 1979). In 1978 and 1979, the Cisco Cultural Resource Study sampled 10\% of two tracts totaling 140,960 acres in northeastern Grand County, Utah (Reed and Nickens 1980). The Central Coal Project survey was undertaken in 1979 across much of central and southern Utah, but included the Tavaputs Plateau. Also in 1979, a 10\% stratified random sampling survey was conducted of 128,000 acres in the Red Wash Oil and Gas Field, located southeast of Vernal and north of the White River (Larralde and Nickens 1980). In 1979, 25\% of 2,030 acres was sampled in the Split Mountain Study Tract located on the Yampa Plateau just south of Dinosaur National Monument (Spangler 2002:149-150). The Mid-America Pipeline Company (MAPCO) Riverbend sampling survey was undertaken in 1979 to 1980 on $10 \%$ of 43,000 acres of proposed oil and gas leases located near the confluence of the Green River and Willow Creek (Norman and Hauck 1980). In 1980, a 10\% sample of 109,400 acres was undertaken in the Seep Ridge Study Tract, located north of the White River (Larralde and Chandler 1981). From 1981 to 1983, a follow-up survey of oil shale lands south of the White River covered a 5\% sample of 320,000 acres in the southeastern corner of Uintah County (Spangler 2002:151-152). In 1982, sampling surveys covered a fraction of 113,000 acres in study tracts at Woodside, Soldier Creek, and Nine Mile Canyon on the West Tavaputs Plateau.

These Class II sampling surveys made significant contributions to the understanding of prehistory in northeastern Utah (Spangler 2002:153-154). These surveys covered all parts of the landscape rather than focusing on river valleys as earlier surveys had done. As a result, the sampling surveys generated substantial information on hunter-gatherer adaptations from cultural periods predating the later agricultural settlements of the Formative Period, which tended to be clustered along waterways. This information includes patterns of seasonal transhumance, subsistence strategies, and fluctuations in population and degrees of sedentism. It is paradoxical that these surveys were undertaken on BLM lands for the specific purpose of identifying parts of 
the landscape where archaeological sites did not occur, so that mineral development interests would "be relieved of pertinent historic preservation law requirements" (Reed and Nickens 1980:52). The ironic results were that these rigorously constructed sampling surveys found prehistoric sites most everywhere across the landscape, albeit at very low densities in some settings (Larralde and Nickens 1980:49).

The Natural Buttes survey covered 3,760 acres in which only 8 sites were encountered (Hauck et al. 1979). Average site density was low, only about 1.5 sites per square mile. All sites were found located near drainages. The Split Mountain survey found that juniper zones correlated with prehistoric site locations, but that all other environmental variables did not (Spangler 2002:149).

In the Cisco study area, sampling survey found a total of 53 prehistoric sites with a density of 1.3 sites per square mile overall (Reed and Nickens 1980). Density varied between the three tracts within the larger survey area, but overall, three sensitivity zones were defined on the basis of vegetational, landform, and hydrological factors. High sensitivity (9.6 sites per square mile) was defined as all areas containing juniper, even parts of sagebrush zones where only small stands of juniper may be present. The medium sensitivity zone includes areas with grassland and all lands (without juniper) located within $0.25 \mathrm{mi}$ of a major drainage. This zone has a density of 3.03 sites per square mile. The low sensitivity zone has 0.5 prehistoric sites per square mile and consists of mesa tops and all lands covered by desert shrub vegetation. Historic sites in the Cisco study area were found to occur in a highly patterned distribution. All were located near major drainages.

In the Red Wash study area, a sampling survey encountered 26 sites with a density of 1.3 sites per square mile (Larralde and Nickens 1980). The survey broke the study area into three sampling strata. Site densities documented within these strata enabled them to identify sensitivity zones. High sensitivity was assigned to areas of juniper woodland with a site density of 3.24 sites per square mile. Such areas could be identified directly from U.S. Geological Survey (USGS) quadrangle maps as wooded tracts. Medium sensitivity was assigned to nonwooded areas located below the 5,300-ft contour line where site density averaged 1.41 sites per square mile. This sensitivity zone included terrain near larger drainages, but also encompassed areas where sand dunes commonly occur. The low sensitivity zone was characterized by an extremely low density of 0.13 sites per square mile. It was defined as all nonwooded terrain above the 5,300-ft contour.

Researchers encountered two major problems in the structure of the Red Wash sampling survey (Larralde and Nickens 1980:41-43). They noted that, in practice, the resolution of 40-acre survey quadrats was found to be too coarse. For example, eight sites were found in quadrats predesignated as being in the "juniper" stratum, yet five additional sites were discovered in direct association with small stands of juniper located within strata defined as "desert shrub" or "drainage." The usefulness of the predefined survey strata was also called into question by the obvious correlation between prehistoric sites and sand dunes. Dune settings had not been predefined and they cross-cut other strata, occurring in desert shrub, near drainages, on ridgetops, and in flat basins. The difficulty in identifying dune formations from existing maps poses a problem in employing these landforms as variables in sampling surveys. 
The MAPCO Riverbend lease area survey was undertaken in 1978 on the northern slopes of the East Tavaputs Plateau (Norman and Hauck 1980). Thirty-nine historic and prehistoric sites were found on 4,320 acres. Prehistoric sites occurred at a frequency of 1 site per 110 acres, or 5.82 sites per square mile.

In the Seep Ridge study area, a sampling survey recorded 40 archaeological sites, with an overall frequency of 2.34 sites per square mile (Larralde and Chandler 1980:91). The density of the 34 prehistoric sites was 1.99 sites per square mile. The survey sampled portions of three environmentally based strata: juniper woodland, dunes, and all other parts of the landscape. Surveyors encountered difficulties in adequately defining dunal areas from maps, and relied on field observations to confirm the nature of predefined sampling quadrats. They defined a high sensitivity zone as all juniper woodland and a 0.6-mi buffer around such wooded areas, along with a 0.6-mi wide riparian zone along the channel of the White River. The high sensitivity zone had a density of 6.08 prehistoric sites per square mile (6.54 sites of all kinds per square mile). The medium sensitivity zone consisted of dunal landforms and boasted a prehistoric site density of 1.01 per square mile. The low sensitivity zone (all other landforms) contained only 0.45 prehistoric sites per square mile. The higher density of prehistoric sites in the high sensitivity zone was attributed to the greater plant food resources available around floodplain marshes along the White River and in the upland piñon-juniper woodlands.

Class III cultural resource surveys were undertaken in the Uinta Basin concurrent with the Class II sampling surveys. Class III surveys involve intensive archaeological survey of specific impact areas. These surveys are sometimes followed up by test excavations designed to evaluate the NRHP significance of individual sites. Hundred of Class III surveys have been undertaken by CRM archaeologists in the Uinta Basin, beginning in the 1970s and continuing to the present. Many of these surveys covered pipeline and utility corridors, roadway and rail line alignments, well pads, strip mine footprints, and other areas related to the extraction of oil, natural gas, coal, and oil shale deposits in the region.

The results of Class III surveys are varied (Spangler 2002:205). Because of the relatively tight focus and project-specific nature of these surveys, they seldom contribute much to the understanding of prehistoric settlement on a regional scale. The Class III work, however, often leads to more intensive investigations at specific sites. Many such investigations have added significantly to the understanding of regional prehistory. One of the most important contributions is a vast corpus of radiocarbon dates from hundreds of prehistoric components. Excavations have also generated good information regarding the prehistoric use of plant and animal resources. Unfortunately, much of this information has not been compiled and synthesized from the numerous unpublished reports that have been generated.

\subsubsection{General Observations}

3.5.1.2.1 Uncertain Prehistoric Cultural Perspective. Institutionally sponsored archaeology in the Uinta Basin in the last 50 years has established a broad cultural history upon which the work of CRM archaeologists has been based. This cultural history is almost entirely 
descriptive and is based upon an extremely tenuous chronology. Uinta Basin prehistory has invariably been placed within the larger context of Great Basin, Great Plains, or Southwest cultural manifestations. The diffusionist perspective forwarded by many researchers has not been validated by the archaeological data.

3.5.1.2.2 Academic vs. Compliance Archaeology. The relative paucity of sites discovered during CRM investigations in the Uinta Basin seems peculiar in contrast to the large numbers of sites reported by academics and amateurs in their earlier surveys. The explanation for this is simple. Academic and amateur archaeologists are free to focus their attention on locations that contain many archaeological manifestations (e.g., Nine Mile Canyon). Contract archaeology, on the other hand, must constrain its focus precisely within the impact areas of specific development projects. Such areas do not always conform to areas of high archaeological site density. This is especially true of northeastern Utah, where prehistoric sites are clustered not only close to permanent water, but in areas where easy access to water, arable land, and piñon-juniper groves overlaps (Spangler 2002:92-93).

\subsection{Problems with Regional Sampling Surveys and Predictive Models.}

Systematic survey has demonstrated that prehistoric site frequency in the Uinta Basin varies with altitude, vegetation, proximity to water, and, to some extent, landform (Spangler 2002:138). For the region as a whole, prehistoric site density averages around one to two sites per square mile, but considerable variation occurs. The lowest site densities are on the order of 0.1 to 0.5 sites per square mile. These densities are associated with areas of desert shrub in lowlands, but also with nonwooded parts of the landscape at higher elevations, such as mesa tops. Moderate densities in the range of one to three sites per square mile occur in grassland and shrub zones within $0.25 \mathrm{mi}$ of water sources, especially where sand dunes are present. The highest densities are associated with piñon-juniper woodland and riparian zones along the major rivers. In such locations, densities range from 3 to almost 10 sites per square mile.

Sampling surveys have quantified the range of archaeological site density in northeastern Utah, but debilitating problems persist. The most obvious of these are the inconsistent results generated by repeated surveys of the same general area (Spangler 2002:144). Various surveyors have utilized some different environmental variables in their surveys; where the same variables were used, however, the resulting frequencies varied by a factor of 2 to 3 or more. For example, in the Red Wash survey, site density in juniper woodland was 3.24 sites per square mile, while at Seep Ridge it was 6.08 sites per square mile, and at Cisco it was 9.6 sites per square mile. In another example, the Split Mountain survey found proximity to water to have no correlation with site location, in direct contrast to the results obtained from the White River area (Spangler 2002:149).

Part of the inconsistency is no doubt due to the choice of environmental variables selected by predictive modelers. The importance that prehistoric peoples placed upon certain environmental variables is, to some degree, a matter of conjecture on the part of archaeologists. Also, prehistoric peoples who inhabited northeastern Utah are likely to have ranged widely, far beyond relatively small study areas focused upon areas of mineral extraction. Thus, it is entirely 
likely that the results of predictive modeling studies in the Uinta Basin are dealing with the remains of fragments of settlement systems, rather than evidence for complete patterns of seasonal transhumance. This focus makes it impossible to reconstruct entire prehistoric adaptive strategies (Spangler 2002:154). In addition, the relative importance of some environmental variables must have changed over time as a result of changing cultural practices and climatic conditions. Chronological data are desperately needed to inject survey results with a diachronic perspective. The predictive models that have been developed in the Unita Basin to date cannot be confidently employed to predict site locations for specific tracts of land in the region.

Nevertheless, CRM investigations have established some basic information regarding prehistoric adaptations in the Uinta Basin (Spangler 2002:206). The multitude of temporary camp sites, small lithic scatters, and quarries found across the landscape represent just part of broader adaptive strategies in the region. The generalized hunting-gathering subsistence strategy does not appear to have changed much throughout most of prehistory, even after horticulture was added to the subsistence routine. Places where plants, animals, and lithic materials were abundant were occupied repeatedly for thousands of years. Inhabitants were mobile, but occupation of the Uinta Basin was continuous throughout prehistory.

3.5.1.2.4 Historic Site Types. Historic sites are relatively abundant in the Uinta Basin (Spangler 2002:143), although many of them may not seem to contain much significance. Especially common are sites associated with the exploitation of gilsonite and oil shale dating from the first half of the twentieth century. Another ubiquitous historic site type is the sheepherder camp, which can date from as early as the 1870 s but which in some cases is still being utilized today.

\subsubsection{Special Tar Sand Areas}

\subsubsection{Surveys and Overviews}

Archaeological research in the STSAs can be divided between the Unita Basin (Argyle Canyon, Pariette, Asphalt Ridge, Raven Ridge, Sunnyside, Hill Creek, and P.R. Spring) and the STSAs to the south (San Rafael, Tar Sand Triangle, Circle Cliffs, and White Canyon). The Unita Basin STSAs have largely been discussed in Section 3.5.1 and will not be repeated here. The largest survey conducted in the southern tar sands area (Figure 3-2) was conducted in 1988 by P-III Associates, Inc. (Tipps 1988). The Class II survey focused on a $27-\mathrm{mi}^{2}$ area that included the San Rafael, Circle Cliffs, and White Canyon STSAs. The survey was to conduct a $5 \%$ survey of each area, develop a locational model for predicting the location of cultural resources, survey an additional 5\% of each area to further assist in the development of the model, and finally to refine the model based on findings of the additional survey. The surveys identified 166 new prehistoric and historic archaeological sites. Fifty of the sites were recommended eligible for listing on the NRHP. The sites found included 29 Archaic sites, 6 Fremont era sites in the San Rafael area, 17 Anasazi sites located in the White Canyon area, 3 Numic sites, 9 Euroamerican sites, and 103 unknown (Tipps 1988). 


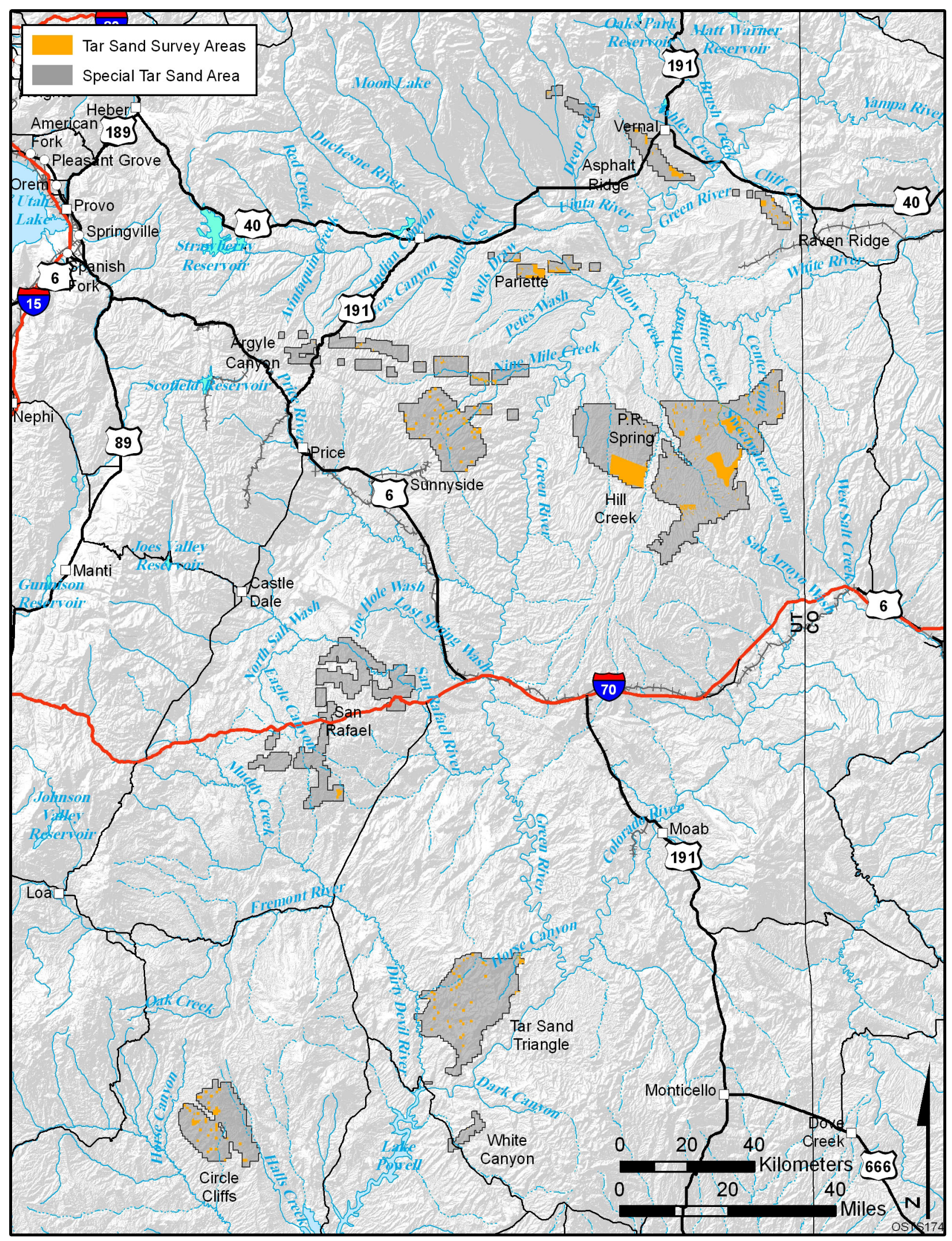

FIGURE 3-2 Cultural Resource Surveys in the Special Tar Sand Areas, Utah 
Site types, frequencies, and distributions varied among the four southern tar sands areas. The Circle Cliffs area contains lithic scatters, lithic scatters with features, rockshelters, and pit-houses, with lithic scatters composing $70 \%$ of all sites. Certain terrain in the Circle Cliffs area was found to be devoid of archaeological sites. As expected, such settings include talus slopes and steep terrain, but also the rims of larger drainages, alcoves along these drainages, and deflated areas with desert pavement. The range of site types in the San Rafael area exhibited more diversity than was found in the other locations. Of the four southern tar sands areas, San Rafael was the only area to contain raw lithic material sources and buried sites. Other site types found at San Rafael include lithic scatters (with and without features), sherd and lithic scatters (with and without features), rockshelters, and historic sites. Sites in San Rafael Swell occur on level terrain in or near piñon-juniper woodland, on large, stabilized dunes or low-relief ridges. The most common site type in White Canyon is the masonry architecture site, suggesting that more permanent habitation took place there. Lithic scatters and sherd and lithic scatters with features were also found in White Canyon. Sites in White Canyon are highly clustered, with $80 \%$ located in a single survey quadrat containing piñon-juniper woodland near deep soil and intermittent water sources. No rock art was found in any of the four areas, but this may be attributable to the nature of the bedrock substrate in the tar sands areas. Such areas do not contain the outcroppings that tend to contain rock art. The most common sites associated with the Archaic period were lithic scatters and lithic scatters with buried features. Fremont sites are represented by sherd and lithic scatters; the masonry architecture is associated with the Anasazi. The Numic speaking groups are only associated with lithic scatters. It should be noted that most of the lithic material during the survey was brought in from other locations. Very little local material was being utilized.

There were two models being developed as part of the study (Tipps 1988). The first looked at environmental factors such as distance to water, slope, and elevation to predict site presence. The survey found that determining site frequency within survey quadrats was crucial. Quadrats that produced only a single site could be distinguished statistically from quadrats that produced no sites or that produced multiple sites, because single sites were limited activity sites located in unusual topographic settings. Such limited activity sites represent extractive activities (e.g., hunting, plant gathering, and lithic raw material procurement); therefore, their locations do not correlate well with environmental variables such as distance to water or percent vegetation cover. The second model used Landsat information to determine which strata would contain cultural material. The model failed to produce any real results because multiple site types were found in similar strata.

The presence of more substantial prehistoric occupations in the vicinity of White Canyon is suggested by the results of an earlier sampling survey undertaken in the nearby Beef Basin (Thompson 1979:151-154). There, a site density of 1 prehistoric site per 20 acres (32 sites per square mile) was documented. By vegetation zone, these frequencies were 1 site per 31 acres in piñon-juniper woodland, 1 site per 12 acres in brushland, and no sites in wasteland areas. Anasazi sites were concentrated in the area at a frequency of 1 site per 56 acres.

Since the 1988 survey, relatively little archaeological research has taken place in the southern STSAs. Linear surveys that tend to result in minor contributions to our understanding of prehistory have been the primary survey type in these areas. In 2002, BYU surveyed the 
locations of 30 abandoned uranium mines in the Circle Cliffs area (Baker et al. 2002). They identified the historical significance of such Cold War era sites in the context of the midtwentieth century arms race. A few compliance surveys have been conducted in advance of relatively small park improvements (e.g., kiosks, signage, and public camp sites), and several archaeological sites have been recorded, but none of that work has resulted in any notable contributions to the understanding of regional history or prehistory. The emphasis on recreational land use in Capitol Reef National Park, Glen Canyon National Recreation Area, and Canyonlands National Park has served to limit most mineral development and, therefore, the need for archaeological survey in the southern STSAs.

\subsubsection{General Observations}

3.5.2.2.1 Site Accessibility and Secondary Impacts. The surveys conducted in the southern STSAs focused on the area containing tar sands strata. Areas located adjacent to these locations contained flat lands that would have a greater potential for containing cultural resources. These areas were not surveyed as part of the past studies but would be open to indirect impacts resulting from tar sands development. It was noted in the surveys that the sites that were found were in generally very good condition unless they were located in proximity to a road. Most archaeological sites identified in the STSAs are clearly evident on the surface. Looting was noted in most locations that were accessible by the public, suggesting that looting issues would greatly increase in the event of development.

3.5.2.2.2 Limitations of Predictive Models. The results of sampling surveys in the STSAs have been highly variable. To a large degree, this can be attributed to the variation in terrain types found in each area. It can also be attributed to the wide geographic separation of the STSAs, practically spanning the length of eastern Utah and extending across prehistoric cultural areas that included highly organized agriculturalists in the south and thin populations of transient hunter-gatherers in the north. It was evident from the surveys that most sites represent short-term seasonal use, except in White Canyon, where the majority of sites are the remains of Anasazi agricultural endeavors. There, the sites tend to cluster in one relatively small area and reflect the seasonal aspect of the occupations. The sampling surveys provide a range of the site densities that can be expected in the region, but the models based on the surveys are not very useful for predicting site locations.

\subsection{RECORDED SITES}

\subsubsection{Uinta Basin}

There are 1,087 sites recorded in the Utah SHPO's database for the oil shale area in Utah (see Figure 3-3 and Appendix B, Table B-3). The SHPO's electronic database uses IMACS coding to identify site types and artifact types. The database contains information on artifact 


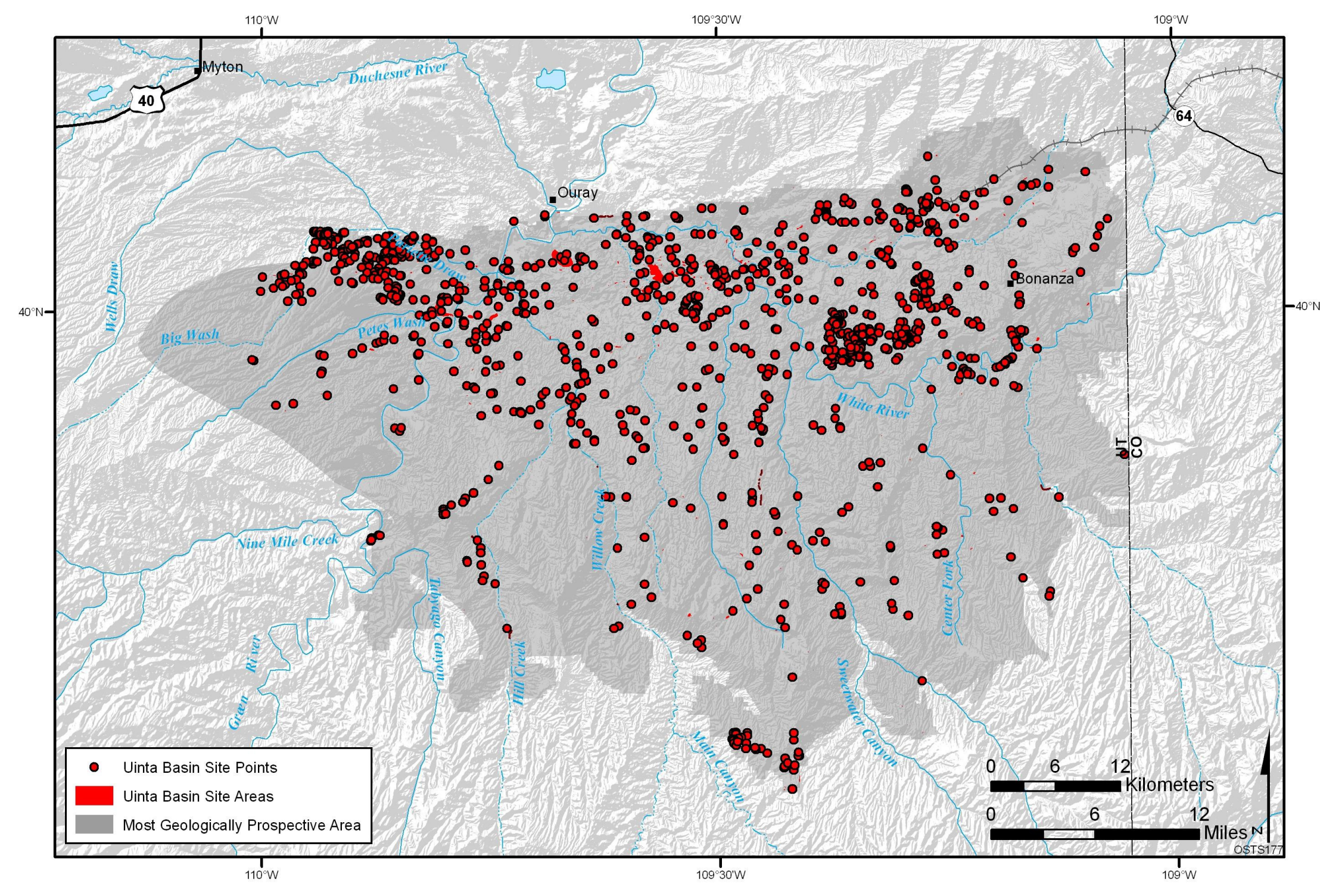


types and environmental factors such as elevation and vegetation. Unfortunately, this information has not been consistently entered for all sites. Sites are entered into the database as polygons, points, or lines. Polygons are sites that are larger than an acre. Points are sites that are less than an acre in size, and lines have some type of linear component such as a historic trail.

Most of the sites identified in the Uinta Basin are from the prehistoric time period. Within the database, there are 563 sites that have no information provided for cultural affiliation. An additional 408 sites are listed as having an unknown prehistoric cultural affiliation. Among the prehistoric sites that have been dated, the Archaic period is represented by 35 sites, with the Fremont period being the next in frequency $(n=27)$. Unfortunately, the database does not characterize sites by their type (i.e., lithic scatter, habitation, etc.). There are 394 historic sites identified in the geologically prospective oil shale area in the Uinta Basin. Of the historic sites, 384 have been designated a theme that is comparable with a site type. Farming and ranching is the most common historic site theme, with 279 sites; 36 sites are listed as having an unknown theme, and 26 are listed as mining themed sites. Other themes listed include railroad, cultural landscape, historic Native American, military, recreation, trail/road, communication, and architecture.

The NHPA requires that resources be evaluated for their potential significance. An archaeological site is considered significant when it has the potential to provide additional information on the history or prehistory of an area. Of the 1,087 sites, 264 have been evaluated as eligible for listing on the NRHP. An additional 606 have been determined ineligible for listing. This leaves 217 known sites that have yet to be considered for listing on the NRHP. Sites that have not been evaluated are protected until a determination is made of their eligibility (see Appendix B, Table B-4).

The cultural resource sensitivity map developed as part of this study for the Uinta Basin was based on the relationship between surveyed prehistoric sites and soil families. Our analysis considered the distribution of 1,089 sites across 13 soil families. The resulting chi-square analysis determined that sites are definitely not randomly distributed across most of the landscape. Areas with soil families mapped as Tipperary-Denco-Badland and Walknolls-Rock outcrop-Potts-Gaynor-Badland contain inordinately high numbers of sites. These areas correspond to the valley of the White River and uplands that compose most of the northeastern third of the Uinta Basin (see Figure D-1). Areas mapped with four other soil families (see Table D-1) contain roughly the number of sites that might be expected if sites were distributed at random across the landscape, and are thus considered areas of moderate site frequency. These areas correspond to higher elevations on the East Tavaputs Plateau south of the White River and westward from Two Water Creek. Areas mapped with five other soil families contain significantly fewer sites than expected. These areas correspond to high-elevation landscapes along the southwestern edge of the Uinta Basin, and also the bottomland soils on the floodplains of the Green and lower White Rivers.

The site frequency pattern is suggestive of overall prehistoric land use. Prehistoric subsistence activity in the Uinta Basin appears to have been concentrated along the White River and in the uplands to the northeast toward Brown's Park. Site frequency diminishes toward the west and south in the drier central part of the basin, despite the presence of the Green and lower 
White Rivers. Site density is inordinately low on the floodplains of these rivers, probably because little formal survey has occurred there, and because sites have been destroyed by stream channel migration and buried by alluvial deposition. Highlands along the southwestern edge of the basin appear to have held little attraction for prehistoric people, although, again, the lack of formal survey in this area may be the reason for the apparent lack of sites in this part of the landscape.

\subsubsection{Special Tar Sand Areas}

The Utah site database identifies 679 sites within the STSAs (see Figure 3-4 and Appendix B, Table B-5). The database uses the IMACS coding system for recording information about the sites. The same system of designating sites as points, polygons, and lines also applies to the STSA information as it did for the Unita Basin sites.

Of the 679 sites identified, 531 are recorded as prehistoric sites. There are 276 prehistoric sites that lack cultural affiliations. The range of prehistoric sites with identified cultural affiliation is topped by Fremont culture sites at 91, with 18 general Archaic sites, 9 Ute/Paiute sites, and 5 Late Prehistoric Sites. The remainder of the sites date to the Late Archaic, Middle Archaic, Numic, Pueblo, or Shoshone cultures. The distribution of prehistoric sites is not even among the various STSAs (see Appendix B, Table B-6). No sites are reported in the Argyle Canyon STSA. More than half of the prehistoric sites identified $(n=280)$ come from the P.R. Spring and Sunnyside STSAs. This is likely due to a combination of greater site densities and a greater amount of survey being undertaken in these areas. There are 80 recorded historic sites found in the STSAs (see Appendix B, Table B-5). Again, historic themes have been assigned to most of the historic sites, providing a sense of the activity types that took place in the STSAs. The most common historic theme applied to sites in the STSAs is farming and ranching $(n=47)$, mining is the second most common $(n=12)$, with historic Native American sites $(n=3)$, architectural sites $(n=2)$, and recreational sites $(n=2)$ being less common. Two other historic themes found in the STSAs are a Civilian Conservation Corps site and a commerce themed site.

NHRP eligibility has been evaluated on more than half of the sites found in the STSAs. There are 275 sites determined eligible for listing on the NRHP in the STSAs; 184 have been determined ineligible, and 219 have yet to be evaluated.

The cultural resource sensitivity map developed for the STSAs was based on the relationship between surveyed prehistoric sites and soil families. The analysis considered the distribution of surveyed sites across several soil families. The resulting $c h i$-square analyses produced variable results (Table D-4). At Argyle Canyon and San Rafael, only one soil family was present, so a statistical analysis was not feasible. Similarly, at Circle Cliffs, all formal surveys had been undertaken within one soil family, preventing valid statistical comparisons of site frequency between soil groups. At Asphalt Ridge and Pariette, chi-square analysis determined that site frequency was not statistically different than that expected for a random distribution. For those areas, statistically valid zones of higher or lower site probability could not be determined. 


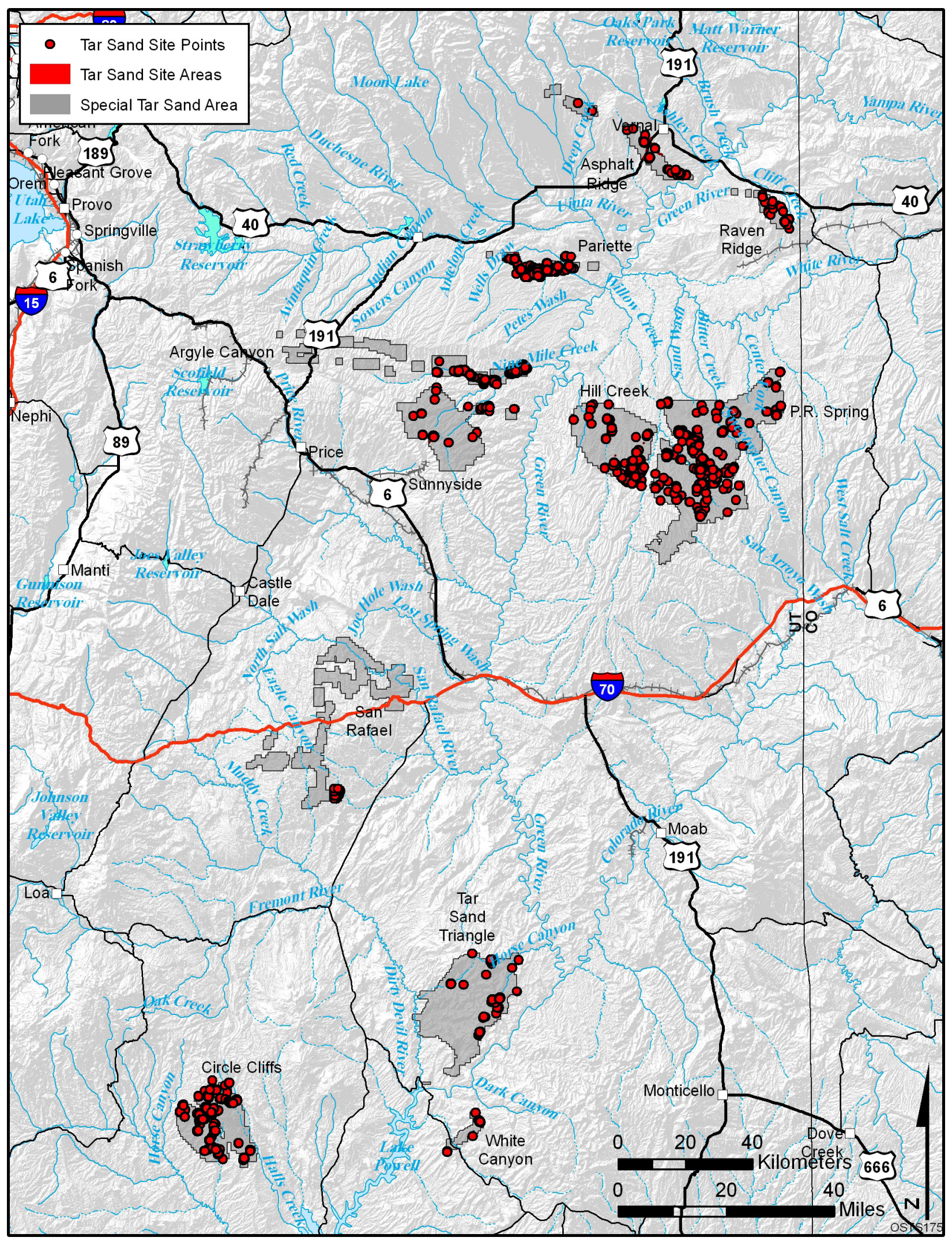

FIGURE 3-4 Cultural Resources in the Special Tar Sand Areas, Utah 
The other six STSAs all evidenced nonrandom soil associations with site frequency. At White Canyon, practically the entire area is in a high probability zone defined by the presence of the Skos-Rizno-Myton-Milok soil family. Statistical conclusions for White Canyon are based on only 43 acres of survey data, however, and should be viewed as suspect. Sites at Hill Creek were found to be overrepresented in two soil families-Rock outcrop-Mikim-Atchee and WalknollsCasmos-Badland. Oddly, the results obtained from the nearby P.R. Spring STSA diverged from those of Hill Creek, with the Rock outcrop-Mikim-Atchee soil family ranking as a medium site frequency zone along with the Winteridge-Towave-Castner-Atchee group, which was considered part of the low-probability zone at Hill Creek. At Raven Ridge, sites were concentrated in areas containing the Rock outcrop-Rentsac-Moyerson-Mikim-Atchee and Tipperary-Denco-Badland soil families. At Sunnyside, high site probability co-occurred with the Walknolls-CasmosBadland soil association. This high probability zone overlaps with a portion of Nine Mile Canyon, which is a known area of high site density. At Tar Sand Triangle, high site frequency occurred within the Wayneco-Moffat-Mido-Mellenthin-Begay-Arches soil family. 


\section{GREEN RIVER AND WASHAKIE BASINS, WYOMING}

\subsection{ENVIRONMENTAL SETTING}

\subsubsection{Physiography}

The Green River and Washakie Basins are located in the Wyoming Basin Physiographic Province of the Rocky Mountain Region. The oil shale areas are surrounded by the Wasatch, Green, Uintah, and Seminoe Mountains and by the Wind River and Medicine Bow Ranges. The overall basin has an area of about 6,700 $\mathrm{mi}^{2}$ (see Extent of Green River Formation labeled Green River and Washakie Basins in Figure 1-1).

The Green River Basin is mainly bounded by escarpments of the Green River and Wasatch Formations (Mason and Miller 2005). The Washakie Basin is a synclinal structure with faulting mainly along its southern and western edges. Its central portion has few faults (DOI 1973). The rim of the basin is formed by rock of the Green River Formation (Mason and Miller 2005).

\subsubsection{Geology, Soils, and Hydrology}

The Green River and the Washakie Basins are separated by the Rock Springs uplift. Each contains sedimentary rock with thicknesses more than $20,000 \mathrm{ft}$.

In the Green River Basin, the uppermost unit is the Bridger Formation of fluvial and paludal (marsh) origin. The underlying Green River Formation is mostly lacustrine basin-fill rock. The Wasatch Formation underlies the Green River Formation and is mostly fluvial and paludal material. The Green River Formation intertongues with both the overlying Bridger Formation and the underlying Wasatch Formation, and it is replaced by these formations, and, in some locations around the basin, by the fluvial Battle Spring Formation boundary (Roehler 1992).

In the Washakie Basin, the stratigraphy is similar; however, the uppermost unit is referred to as the Washakie Formation rather than the Bridger Formation (Roehler 1992). The Green River Formation here is composed of four units. The Laney Member is up to 1,300 ft thick and consists of sandstone, siltstone, and mudstone, with generally low-grade oil shale zones. The Wilkins Peak Member is about $400 \mathrm{ft}$ thick. Its upper portion is mudstone, siltstone, and sandstone, with minor amounts of oolitic and algal limestone and thin beds of low-grade oil shale. The lower portion is mainly low-grade to moderate-grade oil shale with algal limestone and siltstone. The Tipton Member is about $200 \mathrm{ft}$ thick and is made up of low- to moderate-grade oil shale with some algal limestone and siltstone. The Luman Tongue is about $300 \mathrm{ft}$ thick and is the lowermost unit of the Green River Formation. Its upper half is mainly low-grade oil shale with some limestone. The lower half is interbedded siltstone, sandstone, mudstone, low-grade oil shale, thin units of moderate-grade oil shale, limestone, shale, and coal. 
The central Green River Basin has economic deposits of trona and halite in the Wilkins Peak Member of the Green River Formation (Roehler 1992). Oil and natural gas are present in the Wasatch, Fort Union, and Mesaverde Formations and have been produced in commercial quantities at locations surrounding the Washakie Basin (DOI 1973). These formations underlie the basin at depths several thousand feet below the lowermost Green River Formation oil shales. Coal is also present below the oil shale in the Green River and Washakie Basins (DOI 1973; Mason and Miller 2005).

The soils of the Green River and Washakie Basins are developed on the Green River, Bridger, and Wasatch Formations (DOI 1973). The soils' textures range from sandy to loamy to clayey. The soil surfaces are mainly level or moderately sloping, though roughly $20 \%$ of the area has steep slopes. Sixty percent of the basin area has shallow soil, with the bedrock within 20 in. of the surface. Erosion rates are generally moderate to high. Because of the aridity, wind erosion is greater than water erosion.

The Green River Basin is part of the Colorado River Basin. Major tributaries of the Green River in the basin include the New Fork, Hams Fork, Big Sandy, Blacks Fork, and Henry's Fork Rivers, and Bitter Creek. The oil shale area in the Washakie Basin is drained by the tributaries of the Little Snake River. Alkali Creek and Vermillion Creek are two perennial rivers draining the basin. Most of the other creeks in the basin, such as Sand Creek, Shell Creek, and Barrow Spring Draw, are ephemeral.

\subsubsection{Climate, Flora, and Fauna}

The Green River Basin lies within the Wyoming Basin ecoregion (Chapman et al. 2004). The Wyoming Basin ecoregion occupies a broad arid basin with scattered hills and low mountains. The climate in the basin is influenced by the surrounding mountain ranges. The predominant vegetation types are grasslands and shrublands. The Rolling Sagebrush Steppe subregion is the predominant subregion within the Green River Basin, with large areas of the Salt Desert Shrub Basin subregion scattered throughout much of the basin. In addition, the Foothill Shrublands and Low Mountains subregion occurs in the southern and eastern portions of the basin. This region is characterized by isolated dry mountain ranges and foothill slopes and includes alluvial fans, hills, ridges, and valleys. Elevations in foothills range from 5,000 to $7,000 \mathrm{ft}$, and more than 9,000 ft in some mountain ranges. Local relief can be up to $800 \mathrm{ft}$. The average annual precipitation is about 14 to 20 in., and the growing season is short to moderate with 75 to 100 mean annual frost-free days. Fine-textured soils occur at lower elevations and primarily support sagebrush steppe and grassland with big sagebrush, rabbitbrush, prickly pear, bluebunch wheatgrass, and Idaho fescue, while rocky outcrops support woodlands of Rocky Mountain juniper, Utah juniper, and mountain mahogany. Higher elevations support Rocky Mountain juniper, lodgepole pine, limber pine, aspen, Douglas fir, and ponderosa pine forests.

The Washakie Basin also lies within the Wyoming Basin ecoregion. The Rolling Sagebrush Steppe is the predominant subregion within the Washakie Basin. This subregion is a wide semiarid area of rolling plains with hills, mesas, cuestas, and nearly level floodplains and terraces. Footslopes, ridges, rolling alluvial fans, and outwash fans occur near the mountains. 
The average annual precipitation is 6 to 16 in., and the area has a moderate growing season with 75 to 100 mean annual frost-free days. Elevations range from 4,900 to 7,200 ft. Local relief can be up to $400 \mathrm{ft}$. Sagebrush steppe shrubland is the predominant vegetation type, with mixed grass prairie predominating in the far eastern portions. The dominant shrub species is Wyoming big sagebrush. Silver and black sagebrush occur in the lowlands, and mountain big sagebrush occurs at higher elevations. Smaller areas of the Salt Desert Shrub Basin subregion are scattered throughout the Washakie Basin. This arid plains subregion is characterized by disjunct playas and sand dunes, nearly level floodplains and terraces, and rolling aluvial fans. Elevations range from 5,800 to 7,200 ft. These areas receive an average annual precipitation of 6 to $10 \mathrm{in}$. and have a moderate growing season with 75 to 100 mean annual frost-free days. Soils are more alkaline and less permeable than in the Rolling Sagebrush Steppe. Vegetation is sparse, consisting of desert shrublands with alkaline-tolerant shrubs and grasses. Shrubs include shadscale, greasewood, Gardner saltbush, bud sage, and big sagebrush. Stabilized sand dunes, which have greater moisture, higher permeability, and lower alkalinity, support a higher diversity of plant species, primarily alkali cordgrass, indian ricegrass, blowout grass, alkali wildrye, and needle-and-thread.

Large areas of the Green River and Washakie Basins lie within the Rolling Sagebrush Steppe subregion of the Wyoming Basin ecoregion. Within this subregion, streams and rivers with mountain headwaters have a moderate gradient with granite or limestone cobble substrates (Chapman et al. 2004). Streams with headwaters in the Wyoming Basin center have a low gradient with finer gravel substrates of shales and are more incised. Small streams in the subregion are weakly intermittent or ephemeral, with substrates of sand or platy shale. Within the Salt Desert Shrub Basin subregion, streams are ephemeral or weakly intermittent; many are incised and flow into playas, which are seasonal with high levels of soluble salts (Chapman et al. 2004). Substrate is typically fine-textured or platy shale gravels. Within the Foothill Shrublands and Low Mountains subregion, streams originate in the nearby Rocky Mountains or are spring-fed streams originating on the higher ranges of the basin (Chapman et al.. 2004). They generally have a steep gradient with riffle/run habitats and plunge pools. Streams generally have limestone or granite cobble or boulder substrates.

In the sand dunes area on the northeastern corner of the Green River Basin, ephemeral ponds fed by meltwater, or flockets, are ecologically important wetlands because of their early season production of invertebrates and nesting habitat for waterfowl (BLM 2004a). Seeps and springs occur within the Jack Morrow Hills Planning Area (BLM 2004a), which includes the northeastern corner of the Green River Basin.

Basin big sagebrush is found as a dominant species along valley bottoms, canyons, and ephemeral streams. Greasewood shrublands occur along playas, desert lakes, ponds, and desert streams, often on terraces above wetter areas of silver sagebrush or basin big sagebrush.

Wetland and riparian areas generally are herbaceous wetlands, herbaceous riparian areas, and shrub-dominated riparian areas. Sedges, rushes, cattails, and willows dominate wetter areas. In addition to margins of streams and bodies of open water, wetlands occur as open meadows that collect moisture in winter and spring. Many wetland areas are seasonally dry and infrequently inundated. Alkaline conditions can occur in areas of limited drainage. Riparian areas 
along major streams support woodlands of various species of cottonwood and willow. Areas of shallow soil along the riparian margin or in rocky areas support predominantly herbaceous communities composed of riparian woodland understory species. Riparian habitats in foothills and mountain areas generally have high moisture levels throughout the growing season. The dominant species are generally willows with an understory of sedges, rushes, spikerush, and grasses. Open meadows and marshes support communities composed of these understory species.

Big game species within the study area include elk, mule deer, pronghorn, bighorn sheep, moose, American black bear, and mountain lion. Presently, the elk and mule deer are generally the most abundant, widely distributed, and sought-after big game in the region (BLM 2004c). A number of the big game species make migrations when seasonal changes reduce food availability, when movement becomes difficult (e.g., because of snowpack), or where local conditions are not suitable for calving or fawning. Established migration corridors for these species provide an important transition range between seasonal ranges and provide food for the animals during migration (Feeney et al. 2004). Water availability is a major factor affecting the distribution of big game species (BLM 2004a).

Small mammals include small game, furbearers, and nongame species. Small game species that commonly occur within the Oil Shale and Tar Sands PEIS study area include blacktailed jackrabbit, desert cottontail, mountain cottontail, snowshoe hare, white-tailed jackrabbit, and yellow-bellied marmot. Common furbearers include American badger, American beaver, American marten, bobcat, common muskrat, coyote, red fox, striped skunk, and weasels. Nongame species include bats, shrews, mice, voles, chipmunks, and other rodent species.

Upland gamebirds that are native to the study area include blue grouse, ruffed grouse, greater sage-grouse, and mourning dove; introduced species include ring-necked pheasant, chukar, gray partridge, and wild turkey. All of the upland game bird species within the study area are year-round residents.

\subsection{REGIONAL PREHISTORY}

The prehistory of the Wyoming region of interest was largely defined by Metcalf (1987). Metcalf based most of his chronology on radiocarbon dates. Since that time, some changes and refinements have been proposed by various researchers to the region's cultural chronology (e.g., Thompson and Pastor 1995). These changes are based on evidence from numerous archaeological sites excavated after Metcalf developed his initial chronology.

\subsubsection{Paleoindian Period}

The Paleoindian Period refers to the era containing the first confirmed evidence of human activity in the Wyoming Basin. The Paleoindian Period begins in roughly 10,000 B.C. and continues to around 7,500 B.C. The Paleoindian Period covers the end of the Pleistocene and the beginning of the Holocene era of today. It was a period of retreating glaciers and abundant 
rainfall. Conditions in the Wyoming Basin were wetter than today and resulted in grasslands and savannah conditions. Evidence for Late Pleistocene megafauna is found in southwestern Wyoming. The animals associated with Paleoindian occupations include mammoths, bison, horse, and camel. With the end of the Pleistocene, the megafauna disappeared and were replaced by modern bison and antelope.

Artifacts associated with the Paleoindian Period are lanceolate points with fluting and basally ground hafts. Most of the evidence for Paleoindian occupation is derived from isolated tool finds or in association with later material rather than from single occupation contexts. The evidence suggests that Paleoindians relied on exploitation of megafauna, mainly bison and mammoth (Frison 1978). Several sites containing butchered mammoth have been found in Wyoming. It is speculated that Paleoindian peoples also relied on smaller animals and plants to augment their diets (Peebles et al. 1983a,b).

Thirteen complexes have been identified on the basis of changes in point manufacture in the Paleoindian Period: Clovis, Goshen, Folsom, Agate Basin, Hell Gap, Alberta, Cody, Frederick, Lusk, Pryor Stemmed, Lovell Constricted, James Allen, and Angostura. Changes in styles became more pronounced after 8,000 B.C. It is not known whether this array of point types resulted from adaptation to changing climates, new population influxes, changes in game, or a combination of these factors.

\subsubsection{Archaic Period}

The Archaic Period refers to the very long span of time from 6,500 B.C. to about A.D. 0 . During this period, there were significant changes in climate and in populations that inhabited southwestern Wyoming. The climate became much drier and the megafauna of the Late Pleistocene completely disappeared. The Archaic is considered a single period because of the continuity in subsistence strategies and relative homogeneity of the technologies being employed. The large lanceolate points of the Paleoindian Period were replaced with small dart points associated with the atlatl. The Archaic Period in Wyoming is divided into two distinct eras: Early and Late. These eras are further subdivided based on locally observed variations.

There is some debate as to the nature of subsistence in the Wyoming Basin during the Archaic Period. Metcalf suggested that on the basis of some discoveries associated with the McKean Technocomplex (tool types associated with the Great Plains), that subsistence in the Wyoming Basin was based on exploitation of bison as is found in the Great Plains (Metcalf 1987). Evidence discovered since the mid-1980s has not supported this theory. While bison were relied upon in some well-watered areas, most of the Wyoming Basin did not support bison herds (Johnson and Pastor 2003). Subsistence relied more on small game procurement and increasingly on vegetation use. This is supported by the discovery of grinding stones as well as pollen and faunal data. McKean Technocomplex material is found in the Washakie Basin but not in association with bison remains (Peebles et al. 1983a,b). The significance of this finding is that it suggests a unique adaptation to living conditions in the Wyoming Basin during the Early Archaic rather than pointing to the outer fringes of a Plains culture. 


\subsubsection{Early Archaic}

The Early Archaic period is subdivided into the Great Divide Phase (6,200 B.C. to 4,500 B.C.) and the Opal Phase (4,500 B.C. to 2,300 B.C.). The Great Divide Phase appears to be a time of low populations; however, very few sites have been excavated. Sites that date to this time period are found in the basin interiors, but there is also evidence of increased use of uplift areas and the foothills at this time. It is assumed that the climate became warmer and dryer in what is called the climatic Altithermal period. Side- and corner-notched projectile points are hallmarks of this period, and there is evidence of increased ground-stone use and plant processing (Creasman 1987). There is no evidence of bison use; there is, however, ample evidence of rabbit and ground squirrel associated with Great Divide sites. Only one pit-house from this period has been excavated (Stainbrook 1999).

By contrast, the Opal Phase demonstrates a proliferation of pit-houses, which has been associated with an increase in population. Many more Opal Phase sites have been identified than Great Divide Phase sites. Pit-houses from this period vary in size and often contain subfloor features such as hearths or storage pits. The varying size suggests differential functions for these structures. Slab-lined pits, a common feature associated with plant use are found at many Opal Phase sites and may be an indicator of increased plant use. Bison remains also appear in association with Opal Phase sites and may be associated with increased human population sizes during this period.

\subsubsection{Late Archaic}

During the Late Archaic period, there appears to be an increase of precipitation and warming, which increased the habitat available for bison. The Late Archaic is also divided into two subphases. The Pine Spring Phase (2,300 B.C. to 800 B.C.) is named for the Pine Spring site where much of the material associated with the period was first identified. The Deadman Wash Phase (800 B.C. to roughly A.D. 200) is characterized by an increase in plant use and more stable populations. There are no major changes to subsistence patterns from the Opal Phase to the Pine Spring Phase. Point types found during the Pine Spring Phase include corner-notched and stemmed projectile points. These points are somewhat similar to Elko and Pelican Lake points, which are found more in the Plains; these point types, however, occur over a long time period, which renders them poor indicators of any specific time period. Changes in technology and subsistence patterns during the Pine Spring Phase are not clearly defined. It is clear though that the pit-houses that were indicative of the Opal Phase are less prevalent in the Late Archaic.

McNees et al. (1992) suggest that an indigenous population with traditions descended from the Archaic populations, was being surrounded by groups tied to the Plains groups with ties to McKean traditions. The internal groups were slowly replaced by those groups with ties to the Plains. However, climatic conditions in southwestern Wyoming were not sufficient to support the bison herds associated with Plains McKean traditions. There is a general increase in bison use but not to the levels found on the Plains. Environmental conditions in the Wyoming Basin are not comparable with those found in the Plains; the Wyoming Basin is colder and drier. In 
general, a relative lack of evidence from across the Wyoming Basin for this period precludes any good understanding of the Pine Spring Phase.

During the Deadman Wash Phase, climatic conditions continued to improve.

Precipitation levels increased over time, which increased the variety of floral resources available. However, the frequency of radiocarbon dates for this period declines during the Deadman Wash Phase. Populations grew steadily during the Early Archaic period but appear to have leveled off or dropped during the Deadman Wash Phase. It is not clear what occurred in the Deadman Wash Phase to reduce the evidence of human habitation. It is clear that populations began to grow toward the end of this phase. Populations continued to grow into the Late Prehistoric Period.

\subsubsection{Late Prehistoric Period}

The two main technological advances that mark the Late Prehistoric Period are the bow and arrow and the introduction of pottery. The Late Prehistoric Period is marked by dramatic increases in population during the first part of this period and dramatic climatic and population changes in the latter part of the period. The bulk of the Late Prehistoric Period is called the Uinta Phase and extends from roughly A.D. 200 to A.D. 1350. The latter portion of the Late Prehistoric is called the Firehole Phase, which continues to the point of first contact with Europeans.

The Uinta Phase is marked by the use of small triangular Rose Spring-style projectile points in the Wyoming Basin. Pottery does not appear until roughly A.D. 650. Pottery associated with the Uinta Phase is called Black Butte Grey. There is considerable discussion among scholars concerning the influence of Fremont cultures from Colorado and Utah in southwestern Wyoming. Fremont cultures practiced horticulture, which is not possible in southwestern Wyoming; however, some clearly Fremont-influenced material is found in the region. It is not clear if the Fremont were actually residing in Wyoming or only influencing local populations. During the Uinta Phase, populations greatly increased. Housepits became a common dwelling type again. Much of the evidence for Uinta Phase pit-houses was discovered in the 1990s (Harrell et al. 1997; Larson 1997; Thompson and Pastor 1995). Toward the end of the Uinta Phase, there is evidence of migrations into southwestern Wyoming by neighboring Plains groups. It is possible that this represents a continuation of the interactions with Plains groups observed with the McKean Technocomplex (BLM 2004b).

The Firehole Phase is characterized by a dramatic drop in population and fluctuations in the climate. The early part of the Firehole Phase is marked by warmer and drier conditions that deteriorate to a colder and wetter climate. The Rose Spring points that were a hallmark of the Uinta Phase were replaced by tri-notched, Desert side-notched, and cottonwood triangular point types. Pit-houses were replaced by teepee rings and wikiups. Although some petroglyphs were found in the Uinta Phase, mainly in association with Fremont material, rock art became more common and widespread during the Firehole Phase. Pottery types found in this period include Boars Tusk and Skull Point Wares (Creasman et al. 1990). 


\subsubsection{Protohistoric Period}

Protohistoric refers to the period when European influence and artifacts first make an impact on native populations. The Shoshone were the main group living in the Wyoming Basin. There is evidence of Crow and Ute in the region as well, with the Northern Arapaho located predominantly to the north. A major change that occurred during this era was the introduction of the horse from Spanish settlements to the south. The horse radically altered native societies by allowing increased mobility and improved resource collection. Bison hunting was greatly improved, as the horse increased the success rate of hunts. Average group sizes also increased during the protohistoric period, possibly influenced by the adoption of the horse into their culture. There is also evidence of increased conflict with neighboring groups during the Firehole Phase. Burials show evidence of violence becoming more frequent.

\subsection{REGIONAL ETHNOHISTORY}

The following discussion is summarized from an ethnohistoric overview (Bengston 2007) completed for the Oil Shale and Tar Sands PEIS.

Eastern Shoshone territory covered most of present-day western Wyoming and possibly northeastern Utah. An even larger range of land was used for hunting buffalo. The Eastern Shoshone generally wintered along the Green River. Shimkin (1986) divided the Eastern Shoshone into two groups, the Buffalo Eaters and the Mountain Sheep Eaters. The Buffalo Eaters centered themselves in the Green and Wind River valleys but migrated over the entire Eastern Shoshone territories. The Mountain Sheep Eaters inhabited the central Rocky Mountain area, including the vicinity of Yellowstone Lake. The Eastern Shoshones tended to form larger, highly militaristic groups or bands (Shimkin 1986). This was likely because of their greater dependence on the buffalo and the more frequent occurrence of warfare with the other Plains tribes. It should be noted, however, that membership in the various bands was fluid and changeable as with other Shoshone bands (Shimkin 1947, 1986).

The lifeways of the Shoshone bands varied according to environment and whether they had horses. The bands that depended on the horse and buffalo hunting, like their Plains counterparts, generally lived in Plains-style tepees. Their subsistence lifeways depended more on hunting and fishing than on plant gathering. The Shoshone bands that had horses relied on buffalo; those bands living near major rivers subsisted primarily on salmon and other fish. The Eastern Shoshone depended mostly on faunal resources supplemented with berries, roots, and seeds.

The predominant territory of the Utes is in southeastern Colorado; however, by the mid-1600s they had acquired horses and had migrated into northern Colorado and Utah and possibly southwestern Wyoming according to Ute oral tradition. The Utes also moved eastward into the Great Plains and adopted a plains lifestyle of buffalo hunting and living in tepees. Northern Arapaho also may have made use of lands in the study area, but there is less documented evidence of this. The Northern Arapaho territory expanded into eastern and northern Wyoming and Kansas from eastern North Dakota and Minnesota after the Arapahos began using 
horses in the early 1700s. The Arapahos specialized in big game hunting and supplemented their diet with roots, berries, fruits, nuts, and tubers.

\subsection{REGIONAL HISTORY}

\subsubsection{Early Exploration and Fur Trading}

The earliest non-native peoples in southwestern Wyoming were fur trappers. The return of the Lewis and Clark expedition in 1806 marked the beginning of the fur trade in Upper Missouri country. The early fur trading companies established posts on the Bighorn and Yellowstone Rivers. They sent trappers like John Coulter roaming as far south as the Wind River valley and the foot of the Teton Range. In part because of the hostility of the Blackfeet, American fur trading shifted southward after 1810. In 1811, a party of trappers led by Wilson Hunt crossed from the Missouri River bound for Astoria, Oregon, by way of the upper Green River valley. These Astorians were probably the first group of Euroamericans to pass through southwestern Wyoming.

The War of 1812 and a crippled national economy effectively closed the expansion of fur trapping in the region until the early 1820s (BLM 2004b:4-5). In 1822, the Rocky Mountain Fur Company was formed in St. Louis. A post was established at the mouth of the Bighorn River in Montana, and parties of trappers were sent into the mountains and valleys to the southwest. They began arriving in the Green River valley in the autumn of 1823. They shortly began encountering British trappers from the Hudson Bay Company encroaching on the region from Canada.

Soon, the traditional method of operating from fixed trading posts was discarded. The fur company began instead to rely upon dispersed gangs of trappers (BLM 2004b:42). Individual trappers would bring in their furs and get resupplied by the company at a central meeting point each summer. The first of these annual rendezvous was held on Henry's Fork of the Green River in 1825. Subsequent rendezvous were located elsewhere in the Rocky Mountains but on the Green River in 1833, 1835 to 1837, and 1839 to 1840 (Zier et al. 1983:1-48). In 1834, the rendezvous was held on the Hams Fork, northwest of Granger.

By the 1830s, other fur trading outfits began competing in the region (BLM 2004b: 42-43). The American Fur Company moved its operations to the West in 1832. In 1833, Captain Benjamin Bonneville joined the competition and built a short-lived post on the Green River. By 1836, the annual rendezvous had swelled to around 300 Euroamerican trappers and hundreds of Native Americans. But the fur resource base was declining rapidly, and changing European fashion increasingly called for silk hats rather than felt made from beaver fur. The fur trade dwindled, and by the early 1840 s, the major companies had dissolved.

The fur trade left little trace on the Wyoming landscape. Remains of rendezvous sites have not been identified archaeologically and may be extremely difficult to locate because of modern development and recent alluvial deposition (Rosenberg 1984:5-6). Individual trapper camps are quite rare, although one site (48SW336) found in the Leucite Hills northeast of Rock 
Springs may be one of them (Rosenberg 1984:6-7). While there is little left to mark the fur trade era, fur traders did discover and relate to others the routes that would quickly become the main thoroughfares for the migration west.

The decline of the fur trade coincided with the beginning of the great westward migration in America. The Oregon Territory was the first major destination for emigrants (BLM 2004b:45). The first transcontinental settler crossed through South Pass in 1840 on his way to Oregon (Thompson and Pastor 1995). In 1842, Captain John Fremont led a party of surveyors from the U.S. Corps of Topographical Engineers to map known trails and explore possible routes through the central Rocky Mountains (BLM 2004b:43). They crossed South Pass and entered Green River Country, passing near what is now Granger and followed the valley of Hams Fork. Part of Fremont's route would eventually become a section of the Overland Trail.

Emigrants continued to move west on the Oregon Trail even as the first routes were being surveyed. Jim Bridger, a former fur trapper, cashed in on the immigrant experience by establishing a fortified supply post on the trail in 1842 (BLM 2004b:43). This fort was abandoned a year later but was relocated and enlarged at a nearby site on the Blacks Fork River in 1844. Fort Bridger had a blacksmith shop and stockyards where worn-out animals could be traded for fresh ones. The post was also a magnet for trade with the Native American tribes of the region, particularly the Shoshone and the Ute. It was the only place for hundreds of miles around where provisions could be obtained.

Fort Bridger later became an important outfitting point for military exploration and mapping parties in the 1840s and 1850s, even as it continued to serve as a resupply point for travelers on the Oregon Trail (BLM 2004b:43-44). In 1849, Jim Bridger guided Captain Howard Stansbury eastward from the fort, on a route that bypassed South Pass but which shortened the distance between Fort Laramie and Fort Bridger by some 60 mi. In 1856, Lieutenant F.T. Bryan surveyed a military wagon road along this route, which would later become part of the Overland Trail.

In 1855, the Mormon Church took control of Fort Bridger. This was one of several actions that led to the so-called "Mormon War" of 1857 in which President Buchanan sent an army under Colonel Albert Sydney Johnson to enforce U.S. laws and to replace Brigham Young, then Governor of Utah Territory (BLM 2004b:44-45). A small advance force from the U.S. Army camped near the confluence of the Hams Fork and the Blacks Fork. They were joined by eight infantry companies in early October of 1857, and the main force under Colonel Johnson in late November. The Mormons hindered their advance by burning all the buildings at Fort Bridger and by capturing and destroying the federal supply train at Simpson Hollow. Johnson established Camp Scott on the Blacks Fork, where his troops stayed through June of 1858 when fresh supplies arrived. The Army then moved into the ruins of Fort Bridger and established a permanent military post there.

Through the period of the American Civil War, raids by Native Americans-not Confederates-threatened the Green River Country (BLM 2004b:44). At the beginning of the Civil War in December 1861, regular troops were removed from Fort Bridger. A volunteer militia was organized to protect the post, but repeated attacks by Native Americans took place at 
stage and telegraph stations in southwestern Wyoming. Three hundred men from the "Mormon Battalion" out of Salt Lake City were sent to guard the stagecoach line. In December 1862, Fort Bridger was manned by a company of "Galvanized Yankees"-captured and paroled Confederate Army soldiers sent to serve the Union on the western frontier.

After the Civil War, regular U.S. Army troops again occupied Fort Bridger (BLM 2004b:44). A garrison operated there from 1866 to 1878. Following an uprising by the Ute in northwestern Colorado in 1879, the fort was again manned through 1890. During that time, a military road was built between Fort Bridger and the new Fort Thornburg in northwestern Colorado. Fort Bridger was permanently abandoned by the military after 1890. It is now a landmark that commemorates the era of frontier settlement in southwestern Wyoming.

\subsubsection{Settlement and Transportation}

The topography of southwestern Wyoming is such that the region became a natural conduit for east-west travel across the North American continent. South Pass, located just beyond the eastern edge of the Green River Basin, provided an easy grade for wagons to cross the Continental Divide in a part of the country that was well watered and plentiful with grazing land (BLM 2004b:45). The pass was commonly used by trappers in the early days. Supplies for trappers' rendezvous were hauled by wagon over South Pass, demonstrating the utility of the route for wheeled transport.

From just a trickle at first, traffic on the Oregon Trail grew steadily in the years that followed (BLM 2004b:47-48). The first handful of missionaries and emigrants straggled along the Oregon Trail from 1836 to 1842. In 1842, John Fremont traveled and mapped the route and prepared a guidebook for travelers. The first large party of emigrants left Missouri for the Oregon Territory in 1843, the year that is considered by many historians to be the real beginning of the great westward migration. Emigrants on the trail west numbered in the low thousands every year for the next five years.

In the Green River Basin, the main stem of the Oregon Trail runs from northeast to southwest. The trail enters the basin following the valley of the Little Sandy River and continues southwest along the Big Sandy River to the Green River. There, the route crosses the river and winds its way across country to the Blacks Fork. The route follows the Blacks Fork upstream to its confluence with the Hams Fork. There, the trail crosses the stream and continues southwest past Church Butte to Fort Bridger. A main shortcut, known as the Sublette Cutoff, passes through the north end of the basin. It branches off from the main trail about half-way between South Pass and Farson, at a point known as Parting of the Ways. There, parties that did not need rest and refitting at Fort Bridger saved many miles on their way to Oregon Territory by heading straight west toward what is now Cokeville, Wyoming, where they rejoined the main stem of the trail. Numerous minor cutoffs and shortcuts flanked the Sublette Cutoff east and west of the Green River. These include the Kinney Cutoff, Slate Creek Road, Baker and Davis Road, etc. A second major shortcut, known as the Lander Cutoff, broke from the main trail near South Pass and followed an even more northerly route westward. 
The Mormon migration to Utah, led by Brigham Young, began in 1847 (BLM 2004b:4748). From Missouri, the Mormons followed the main stem of the Oregon Trail through the Green River Basin, but they continued southwest from Fort Bridger to reach Salt Lake. Over the years, some 70,000 Mormons-many using handcarts rather than wagons-made the overland journey on the Oregon Trail. The Mormons continued to emigrate to Utah along this route until rail service was established in 1869. Unlike most other travelers, the Mormons improved the trail for those who would follow. They established mileposts, toll ferry crossings, and camping spots, and improved the road itself where necessary.

The discovery of gold in California created an enormous surge of traffic on the Oregon Trail, starting in 1849 (BLM 2004b:48). While some 12,000 emigrants had traveled the trail in all the years before 1849, numbers swelled to around 30,000 in 1849 and 55,000 in 1850. A cholera epidemic limited the numbers in 1851 , but by 1852 , another 50,000 emigrants were on the westward trail again. By that time, gold fever had subsided and most of the emigrants were once again farmers bound for Oregon Territory.

The number of emigrants on the Oregon Trail continued to dwindle even as alternate routes were sought and roadways were improved. In 1857, Congress authorized the construction of a number of wagon roads across the western territories (Rosenberg 1984:7-26; BLM 2004b:52-61). Frederick Lander was appointed chief engineer for trail segments that passed through the Green River Basin. He sent surveyors into the region to survey and examine all existing routes. They reported that the Sublette Cutoff was not worth improving because of its long stretch of waterless desert. They also reported numerous minor cutoffs and shortcuts running westward from the Big Sandy toward the Hams Fork. Most of these alternate trails were designed to avoid the so-called "Big Sandy Desert," while still striking in a westerly direction. The Hams Fork Cutoff followed the north side of the Hams Fork valley from the mouth of the stream northwesterly to the main stem of the Sublette Cutoff north of Kemmerer. The Blacks Fork Cutoff diverged from the Oregon Trail at Granger and headed northwesterly upstream to rejoin the main trail north of Fort Bridger. Wagon wheel ruts are still visible along many surviving segments of the Oregon Trail and its many cutoffs, and some of these trail sections have been assigned archaeological site numbers.

With the approach of the Civil War, the Pony Express was established. Previously, mail service to the West Coast had followed a southerly route, but the insurrection rendered that untenable. Regular cross-continental mail service was rerouted to the Oregon Trail through the Green River Basin. Stage stations were established at regular intervals along the route. Seven Pony Express stations were located in the Green River Basin. From northeast to southwest, these included stations at Little Sandy, Big Sandy, Big Timber, Green River Crossing, Michael Martins, Hams Fork (Granger), and Church Butte. The Oregon Trail/Pony Express route was considered circuitous for mail riders and subject to the depredations of the natives. It operated for little more than a year from April 1860 to October 1861.

The greater Oregon Trail system is considered to be of national historic significance. It has been added to the NRHP and is locally designated by the archaeological site numbers 48SW827 and 48UT261 (Thompson and Pastor 1995:115). The trail system's historic significance is due to its key role in the fur trade and the great nineteenth century westward 
migration (Rosenberg 1984: 26). The trail system is also of local and statewide historic significance because of its use in the settlement of western Wyoming and its use for local trade, travel, ranching, and military operations well into the twentieth century. Several of the cutoffs, former ferry locations, and isolated graves associated with the Oregon Trail have been identified as separate sites and have been assigned historic site numbers (Thompson and Pastor 1995).

A new, more southerly mail delivery and stage route, the Overland Trail, superceded the Pony Express route in 1861 (BLM 2004b:61-63). The Overland Trail passed from the vicinity of Laramie, Wyoming, on a more direct east-west line through the desert country of the Great Divide Basin, rejoining the Oregon Trail route near Granger. Stage stations were established along the route at 10- to 15-mi intervals, and a telegraph line linked the stations. Teams were changed at the stations, where fresh horses were stabled. There were 25 stations in Wyoming Territory, including 4 in the Green River Basin. From east to west, these were located at Green River, Lone Tree, Hams Fork (Granger), and Church Butte. Despite the relocation of the trail, the Overland Stage Stations became the focus of attacks by unfriendly tribes. Attacks were common through the 1860s, and many stations were burned to the ground, stock was run off, and personnel were killed. The 1867 Peace Commission negotiated an end to these raids.

The dream of a transcontinental railroad had been envisioned since the early nineteenth century, but the reality of it did not appear until much later (BLM 2004b:63-65). Early surveying expeditions identified several potential routes through the Rocky Mountains. After much debate, the U.S. Congress approved a charter for the first transcontinental line in 1861. It would run from Omaha, Nebraska, westward to California, roughly following the Overland Trail route through southern Wyoming. Construction was delayed by the Civil War, but in 1865, the Union Pacific Railroad began pushing west. The line reached the Green River Basin in 1868. A year later, the transcontinental line was complete. The Union Pacific main line, which is still in active use, is considered eligible for listing on the NRHP and has been assigned site number 48SW6357 (Thompson and Pastor 1995:124). Various sidings and other facilities along the Union Pacific line have been identified as separate historic sites. Among these is the Granger Railroad Station (48SW6364) (Thompson and Pastor 1995:127).

As the railroad construction moved west, temporary tent towns sprang up at the railhead. Some of these camps disappeared almost as soon as the railhead moved on. Some, such as the towns of Rock Springs and Green River, managed to grow and survive until the present day. Others persisted for only a few years before dwindling to obscurity. One of these towns was Bryan, located at the crossing of the Blacks Fork west of Green River. Railroad officials temporarily established their headquarters at Bryan until land became available at Green River. Bryan was one of the lawless "roaring towns" of the Old West and was estimated to have once had a population of 5,000. Today, the place is empty but for the old cemetery on a hill overlooking the town site.

The new rail service effectively shut down stagecoach and mail delivery on the old Overland Trail, but several side routes still operated (BLM 2004b:65-66). After gold was discovered at South Pass in 1867, freight and stagecoach routes were established running from various towns on the rail line northward to South Pass. These included routes from Rock Springs, Green River, Bryan, Granger, and Fort Bridger. The Bryan to South Pass City route was 
in heavy use for several years beginning in 1867, but by the late 1880s Bryan had largely disappeared and traffic shifted to Green River and Rock Springs. Lengthy segments of all these wagon roads to South Pass extend through the Green River Basin. Several other old wagon roads have been identified in the basin, including the Granger to Green River Road (48SW8660) and the Bryan to Browns Park Road (48SW8976).

In 1881, the Union Pacific Railroad began construction of a direct rail line to the Pacific Northwest. This venture was incorporated as the Oregon Short Line Railroad (Rosenberg 1984:27; BLM 2004b:65). The new line diverged from the main east-west line at Granger and ran northwest following the Hams Fork to Kemmerer. From there it continued northwest into Idaho and Oregon. The line was completed in 1884. Construction of the rail line spurred development of the coal fields around Kemmerer. The rail line is considered eligible for NRHP listing and has been assigned site number 48LN2327 (Thompson and Pastor 1995:125-126).

In southwestern Wyoming, the railroad provided the most reliable mode of travel through the early twentieth century, when the advent of the automobile sparked development of improved roadways (BLM 2004b:66-68). The first transcontinental automobile journeys in the early years of the twentieth century followed the old wagon trails through the Green River Basin. In 1913, the Lincoln Highway was laid out following the old route of the Overland Stage Trail between Rock Springs and Granger, and thence along the even older Oregon Trail route from Granger to Fort Bridger. The Lincoln Highway was developed through private contributions and state and federal funds. Improvements continued through the 1920s. In 1925, the section of the Lincoln Highway east of Granger became U.S. Highway 30. The Lincoln Highway route in the Green River Basin was later closely paralleled or directly overlain by Interstate 80.

\subsubsection{Oil and Coal Mining}

Pioneers and early settlers noted the presence of oil seeps at various spots throughout southwest Wyoming, but development and exploitation were slow in coming (Rosenberg 1984:46-55). In the early days, there was little demand for oil beyond its use in lubricating wagon wheels. Oil was discovered in 1907 in what would become the La Barge oil field in Sublette County, northwest of the Green River Basin. Significant production would not occur there until the early 1920s. Oil from the La Barge field was trucked to the rail line at Opal until a 4-in. pipeline was built in 1928. Drilling activity continued in the LaBarge field until 1952.

Coal deposits were identified in southwestern Wyoming from before the time the Overland Trail was established (Gardner and Flores 1989:6-8). In 1849, Howard Stansbury noted abundant coal outcrops at Green River and from Rock Springs eastward along Bitter Creek to Point of Rocks. When the Overland Trail was laid out, some stage stations along the route appear to have been sited near coal outcrops specifically so that fuel would have been available for the blacksmith shops and for general heating purposes. Later, the Union Pacific rail line was routed near these readily accessible coal seams, since the fuel was needed to power the locomotives. Commercial mining at Rock Springs began with the arrival of the railroad, which 
provided both the demand for and the means by which to haul away the coal. Coal mining in the vicinity of Rock Springs continued through the end of the nineteenth century, all of the twentieth century, and is ongoing today. Outlying prospecting pits, old mine shafts, and abandoned camps are some of the physical reminders of historic early coal mining operations in the area.

\subsubsection{Ranching}

Settlement across the landscape of southwestern Wyoming began with the first ranching operations established after 1867 (Rosenberg 1984:35-46; BLM 2004b:68-71). The railroad made ranching possible by providing a shipping point for livestock. From the main east-west rail line, ranches spread north and south, up and down the Green River and its tributaries. These ranches raised cattle or sheep and were situated on permanent streams roughly halfway between the summer range in the foothills and the winter range in the desert basins. The early ranches were fairly small family operations, but after 1880 , very large cattle operations were started up, some with the help of foreign investors. Livestock were kept on the open range until after the disastrous winter of 1889 to 1890, when cattle herds were decimated. Thereafter, ranchers began growing hay to serve as winter feed. Conflicts between cattle and sheep ranchers in the 1890s eventually were quelled as the open range was fenced, and later, as federal agencies regulated the use of public range lands.

Ranching is a historically significant industry in southwestern Wyoming (Rosenberg 1984:39-40, 45-46). Cattle raising provided the single greatest impetus to settlement away from the main line of the Union Pacific and continues to be economically significant to the state. Sheep raising was also an important factor in the settlement and economic development of Wyoming. Sheep ranching rendered semiarid land economically productive and served to broaden the economic base that led to the growth and development of regional towns. Numerous homesteads and ranches have been recognized as historic sites in the Green River Basin (Thompson and Pastor 1995:130). Several irrigation ditches in the Hams Fork and Green River valleys have been identified as potential historic engineering structures (Thompson and Pastor 1995:131-132).

\subsection{PREVIOUS RESEARCH}

\subsubsection{Surveys and Overviews}

A file search of the Wyoming SHPO Cultural Records Office (WYCRO) database showed that 4,850 archaeological investigations of discrete land parcels (not 4,850 reporting documents) have been conducted within the geologically prospective areas for oil shale development within the Green River and Washakie Basins in Wyoming between 1955 and 2005 (Figure 4-1). The earliest cultural resource surveys for this area were conducted by the University of Montana in 1955 for a CIG Pipeline project. The survey of six CIG linear segments predates the NHPA of 1966, which has been the main driver for conducting cultural resource 


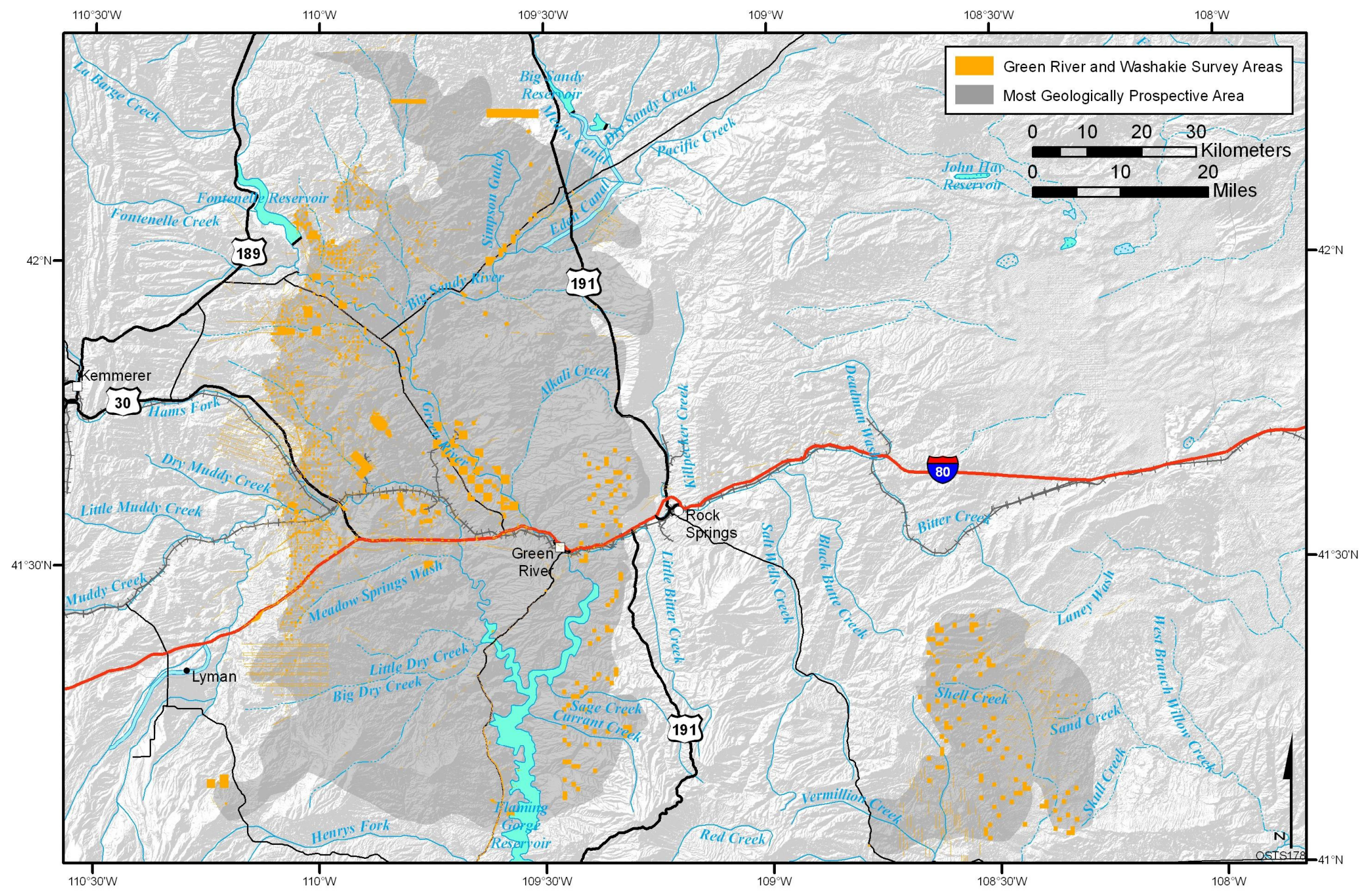

FIGURE 4-1 Cultural Resource Surveys in the Green River and Washakie Basins, Southwestern Wyoming 
investigations. Between 1975 and the end of 1979, 442 investigations were conducted in the study area, with more than half of those conducted in 1979. These investigations were in support of pipeline projects, drill holes, and railroad spurs. It is during this time (1975 and after) that cultural resource investigations become more standardized. Between 1980 and the end of 1989, 1,449 investigations were completed. The number of block (contiguous area) or linear investigations conducted in the 1990s increased to 2,319 surveys. Between 2000 and 2005, 634 investigations had been completed. No investigations have been reported for 2006.

Discussions for each basin follow in Sections 4.5.1.1 and 4.5.1.2. These discussions focus on the archaeological surveys that have been completed. Section 4.5.2 presents the general observations gleaned from the review of the survey information for the study area. Section 4.6 contains a discussion of the types and number of cultural resource sites found in the Wyoming study area.

\subsubsection{Green River Basin}

Past archaeological investigations in the most geologically prospective oil shale area of the Green River Basin study area total 4,315 according to the WYCRO database. These investigations, predominantly linear and block survey segments, are documented in 2,270 reports. Of these investigations, 6 linear segments were surveyed as early as 1955 . Between 1975 and 1979, 426 investigations were conducted. The number of investigations rose to 1,322 in the 1980 s. During the 1990 s, roughly 2,170 surveys were conducted in that 10 -year period. However, between 2000 and 2005, only 391 archaeological investigations had been completed, reflecting a significant drop in survey activity. These archaeological investigations include a Class I overview (a document that provides a summary of archaeological activity in an area), Class II sampling surveys that look at portions of a project area, Class III intensive surveys that look at a total project area, a data recovery and mitigation plan, mitigation/major excavations, monitoring, site testing/NRHP evaluation, snow monitoring, and an "other" category; several records have no project type data reported. The majority of the surveys conducted in the Green River Basin were Class III surveys $(2,109)$. Only 13 Class II surveys were performed in the Green River Basin; the last one was in 1986. The final 139 surveys fall into various other survey types. Appendix C, Table C-1, contains a listing of the archaeological investigations that have been conducted in the area determined to be the most geologically prospective for oil shale development within the Green River Basin. The investigations were conducted for a variety of projects, including pipelines, mine blocks, well pads, core holes, access roads, range management, seismic, snow fencing, telephone/buried cable, and other miscellaneous projects.

Although not yet added to the data file provided by the Wyoming SHPO, a Class I overview was recently prepared for the BLM Kemmerer Field Office Planning Area (BLM 2004b). Of relevance to this study is the easternmost portion of the planning area. This area is identified in the Kemmerer Class I Overview as the Green River Basin Subregion. Within the Kemmerer planning area, this subregion contains the greatest concentration of recorded sites. This is largely the result of 30 years of archaeological investigations for the Moxa Arch Natural Gas Field in an area of concentrated prehistoric land use. In addition, many significant historic 
transportation corridors go through this subregion, including the Oregon, Mormon, California, and Pony Express Trails; the Union Pacific Transcontinental Railroad; the Oregon Short Line Railroad; the Lincoln Highway; and the Opal Wagon Road. The Kemmerer Class I Overview provides a detailed cultural chronology and a mostly tabular account of sites and surveys, as well as monitoring efforts, site testing and evaluation projects, and major excavations, within each of the planning area's subregions. The main purpose of the Kemmerer Class I Overview is to provide useful information at a regional level to the BLM for managing cultural resources on lands for which it has stewardship responsibilities. The incorporation of information from this overview report into future archaeological investigations within or adjacent to this portion of the Kemmerer Field Office Planning Area is recommended. An additional Class I overview listed in the WYCRO database that covers a portion of the project area is the Whiskey Buttes 84 Pipeline Overview, prepared by Independent Archaeological Consultants in 1994.

In 1995, the Rock Springs District of the BLM requested that a summary report for cultural resource information be compiled as part of the Moxa Arch Environmental Impact Statement (Thompson and Pastor 1995). The report People of the Sage: 10,000 Years of Occupation in Southwestern Wyoming summarized much of the archaeological information gathered for the region and attempted to identify where further research was needed. The project area for the report is west of the Green River Basin in the Kemmerer Resource Area. The report provides methodological suggestions and research questions. Some of these findings are included in Section 5. A major recommendation of the report was to focus future research away from pure compliance archaeology where excavations only take place within the project area, and instead to conduct research on sites that date to periods for which information was lacking.

Class II surveys were conducted primarily during the 1980s when land managers were attempting to discover methods for managing cultural resources on very large land holdings. A focus of much of the Class II work performed during the 1980s was the development of models for predicting areas that are likely to contain cultural resources. The attempts met with mixed success.

A survey undertaken in 1991 tested a previously developed model for prehistoric site location near Seedskadee National Wildlife Refuge in the Green River (Wilde 1992). Researchers found their results at odds with an earlier predictive study, in that the lower terrace $\left(\mathrm{T}_{2}\right)$ of the Big Sandy River produced the highest density of sites (1 site per 45 acres). Alluvial flats produced 1 site per 77 acres and the upper terrace $\left(\mathrm{T}_{3}\right)$ produced 1 site per 1,000 acres. The mesa top zone was also ranked low, with 1 site per 333 acres, although investigators noted that this density increased with proximity to the Green River (Wilde 1992:85).

Of the Class II surveys, only one project examined both the Green River Basin and the Washakie Basin. The survey was conducted in 1981 to 1983 by Metcalf-Zier Archaeologists, Inc. (Peebles et al. 1983a,b). The survey was a 23,000-acre Class II survey conducted between 1981 and 1983 partly in the hope of developing a model for predicting archaeological site locations. The study area included a portion of the Green River Basin and a portion of the Washakie Basin. The results were presented in two separate reports (see the Washakie Basin discussion below for a summary of the Washakie report). The Metcalf-Zier study remains one of 
the largest ever undertaken in southwestern Wyoming. The combined survey represented a $10 \%$ sample of the 230,000 acres of BLM land that made up the project area.

The survey identified 194 sites in the Green River Basin and 173 isolates. The site types identified include 91 prehistoric multiple activity sites (habitations), 84 prehistoric limited activity sites (secondary reduction sites), and 19 historic sites. The Cherokee Trail also passed through the survey sampling area. The prehistoric sites cover the known range of human habitation in southwestern Wyoming from the Paleoindian to Late Prehistoric periods. Historic sites range in date from 1852 to the late twentieth century.

The model developed from the survey identified six key environmental variables important in predicting site location in the Green River Basin (Peebles et al. 1983a:164): (1) vertical distance to dependable water, (2) slope, (3) relief within a 0.25-mi radius, (4) quality of the view, (5) elevation, and (6) the presence of juniper. Multivariate discriminant analysis was used to statistically quantify the relative predictive power of these variables. The resulting discriminant functions predict site presence with $94.5 \%$ correctness of fit. Site absence is correctly predicted with a lesser accuracy of $78.5 \%$. Overall, the model's prediction rate is $88 \%$, which is extremely high for these types of predictive studies. Of course, the model has not been tested against an independently collected data set from within the Green River Basin (Peebles et al. 1983a:165).

\subsubsection{Washakie Basin}

On the basis of the GIS data obtained for this Class I overview, 535 different survey blocks (areas) or linear segments underwent archaeological investigation (predominantly Class II and Class III field surveys) in the Washakie Basin. These investigations are documented in 96 individual survey reports. The number of investigations has increased steadily over time. In the 1970s, only 12 blocks or linear segments were investigated. The number of areas investigated increased to 121 during the 1980s. There were 154 survey blocks or linear segment investigations completed in the 1990s, and, thus far, 236 investigations have been completed in the current decade. Appendix C, Table C-2, provides a complete listing of the archaeological investigations that have been conducted in the area that has been determined the most geologically prospective for oil shale development within the Washakie Basin.

Sixty-eight of the survey blocks within the geologically prospective footprint of the Washakie Basin were investigated during the Class II sampling survey of the Washakie Basin by principal investigator Michael Metcalf in the early 1980s (Peebles et al. 1983b). One additional block was investigated as part of a separate Class II sampling survey conducted by TRC/Mariah and Associates.

Of the 460 block and linear segments identified as Class III intensive surveys in the Washakie Basin, most were associated with seismic line, pipeline, well pad, and road access projects. Several of these investigations were identified as range management or miscellaneous. 
The remaining investigations within the Washakie Basin include one historic overview evaluation for a pipeline project; three monitoring investigations, one for a pipeline project and two for a road access project; and two site testing investigations/NRHP evaluations associated with a road access project.

As stated above, the Metcalf-Zier Class II inventory of the Washakie Basin was a $10 \%$ random sample survey of 230,000 acres of public land (i.e., 23,000 acres surveyed) for the BLM Rock Springs and Rawlins Districts (Peebles et al. 1983b). The project was designed to develop a predictive model for cultural resource site locations in the basin. Just less than $50 \%$ of the quadrats they investigated fall within the geologically prospective area (i.e., 68 of 144 total quarter section [160-acre] sample units).

A total of 279 sites and 306 isolated finds were recorded in the 144 sample units. Of this total number of sites, 273 are prehistoric and 6 are historic. In addition, the investigators noted that 6 prehistoric sites and 13 historic sites, including portions of the Cherokee and Overland Trails, had also been previously recorded in the study area. The types of sites encountered include prehistoric habitation sites $(n=69)$; short-term camps $(n=59)$; limited activity sites, such as lithic reduction and tool use sites $(n=70)$; sites of undetermined function $(n=30)$; and primary and secondary lithic procurement sites ( $n=5$ and $n=46$, respectively). Approximately $75 \%$ of these prehistoric sites lacked diagnostic artifacts and could not be classified temporally; the remaining 25\%, however, included sites representing the Paleoindian through Late Prehistoric Period occupations. Historic site types dated from the late nineteenth century and included (1) corrals, (2) other structures, and (3) trash scatters.

The predictive model developed from this Class II investigation delineates high and low site density on the basis of elevation. Areas within the Washakie Basin with elevations greater than 7,400 ft were identified as low site density and areas below 7,400 ft, where the sand dune fields occur, as high site density. Elevation and the presence/absence of sand dunes were identified as the "most potent predictors" of sites (Peebles et al. 1983b:146). The presence of sites (from all time periods) is predicted at $84 \%$ accuracy.

\subsubsection{General Observations}

\subsubsection{More Surveys, Smaller Surveys}

Many of the investigations listed in the inventory data were conducted in response to development, although some investigations were undertaken by the BLM pursuant to its Section 110 stewardship responsibilities under the NHPA. Most of the development in the project area relates to the oil and gas industry. As energy prices rise, the level of development also rises. As a result, years where more surveys are conducted correlate with increased development. These points appear to be the late 1970s and early 1980s and the mid-1990s. Another trend is that the number of acres examined per survey is, in general, decreasing. During the 1980s, numerous block surveys were undertaken that examined 160 acres or more at a time. The majority of the surveys conducted in the late twentieth century and early twenty-first century 
examine areas less than 10 acres in size. This is at least partially an indicator of a reduction in large-scale Section 110 activities and increases in the development of smaller areas for more targeted activities (such as those associated with oil and gas well development). The net result is that more surveys are being performed of smaller areas, and thus less acreage is being examined for cultural resources.

\subsubsection{Effectiveness of Existing Predictive Models}

Predictive modeling efforts undertaken to date in southwestern Wyoming are adequate for current management practices. Relative to the Piceance Basin, few predictive models have been developed for the Green River and Washakie Basins. The results of these models have been quite successful, with high predictive power (on the order of 78 to $94 \%$ accuracy) assigned to estimates of both site and nonsite locations (Peebles et al. 1983a,b). The success of these models may be attributed to the homogenous environmental conditions found within the topographic zones selected as variables in the two basins. There seems to be little room for improvement in the existing models, although on-the-ground survey would be in order if tests of the models are desired.

\subsection{RECORDED SITES}

The total number of recorded sites within the geologically prospective oil shale areas of the Green River and Washakie Basins based on GIS data provided by the Wyoming SHPO in 2006 is 7,466 sites (Figure 4-2). This total includes 6,522 sites in the Green River Basin and 944 sites in the Washakie Basin (Appendix C, Tables C-3 and C-4). Because of the programmatic nature of the oil shale and tar sands project, which broadly considers potential development over a 20-year period, a detailed description of sites, as is common in many Class I overviews, is not warranted here. Project-specific investigations and file searches pertaining to specific project locations would be needed prior to specific development activities to satisfy Section 106 requirements. Although this Class I document can serve as a general overview of previous investigations and offer some recommendations for future investigations in the region, any attempt to rely on this document to enumerate sites and surveys for a project-specific evaluation in a portion of the study area would not meet Section 106 requirements. Because of the amount of development occurring in the region, the GIS data used in this analysis are expected to be outdated relatively quickly and especially by the time commercial development is projected to begin in Wyoming in 2012; this assumption is based on the historical numbers of investigations per decade provided in Sections 4.5.1 and 4.5.2.

The cultural resource sensitivity map developed as part of this study for the Green River and Washakie Basins was based on the relationship between surveyed archaeological (mostly prehistoric) sites and soil families (see Appendix D). In the Green River Basin, our analysis considered the distribution of 9,991 sites across 15 soil families, one of which was actually the now-inundated floodplain of the Green River beneath Flaming Gorge Reservoir. In the Washakie Basin, the analysis considered 1,169 sites within 4 soil families. The resulting $c h i$-square analyses determined that sites are definitely not randomly distributed across the landscapes in 


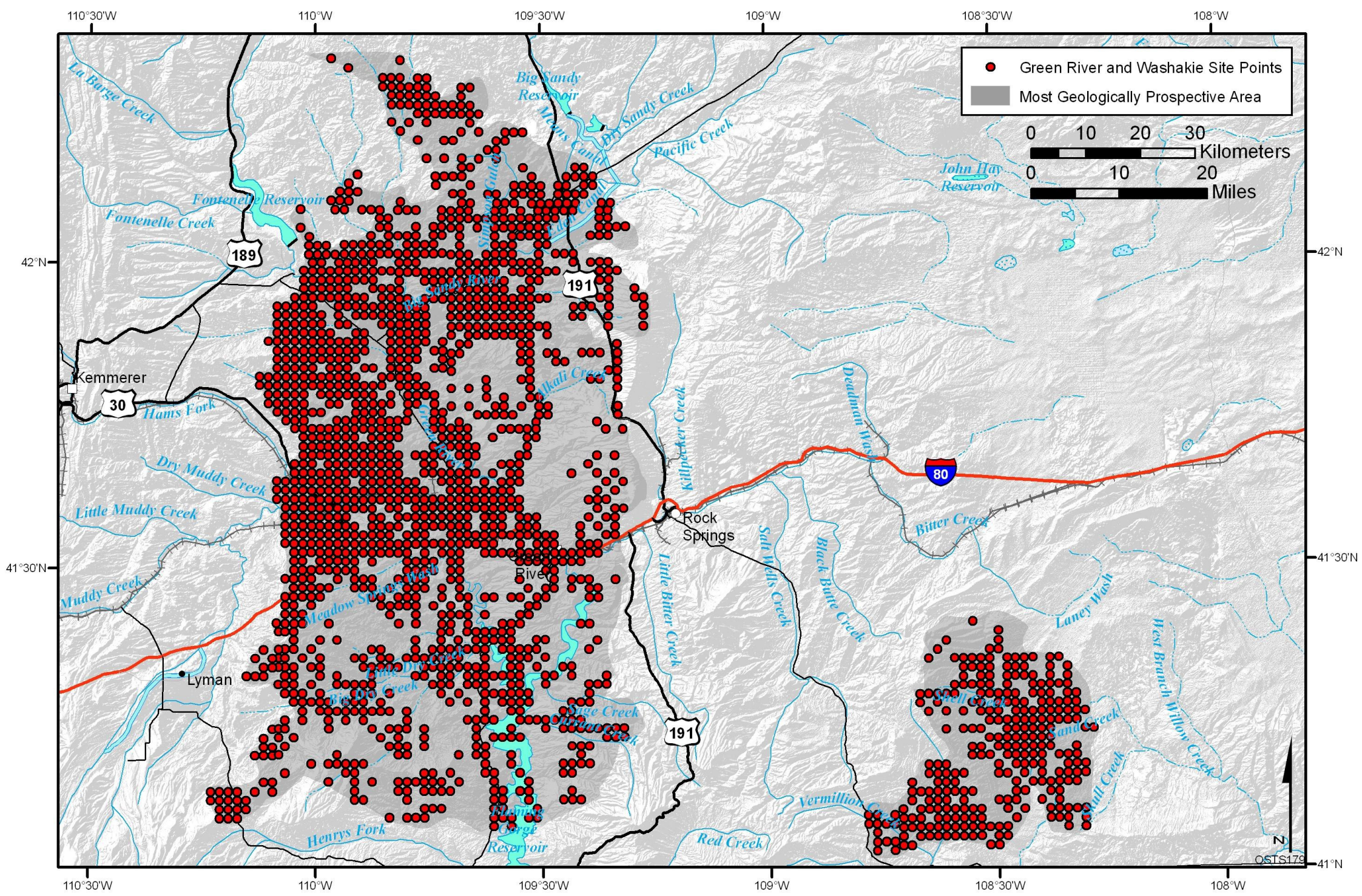

FIGURE 4-2 Cultural Resources in the Green River and Washakie Basins, Southwestern Wyoming 
either basin. In the Green River Basin, high site frequency is correlated with 10 different soil families. A direct relationship between soil type and prehistoric land use is difficult to readily determine since many different environmental factors were obviously in play. One obvious correlation is with the area now covered by Flaming Gorge Reservoir, which contains many sites that had been recorded prior to the damming of the Green River. This area, mapped as a single soil unit, actually is composed of many soil families, all of which have been inundated by the reservoir. Other soil families appear to be correlated with high site densities in open or somewhat broken terrain where sand dunes are present. Perhaps counterintuitive, high site density does not conform to permanent stream valley (except along the Green River). Instead, higher site densities correlate with the soils of dissected plains and low, broken country.

Low site density in the Green River Basin correlates with only two soil families (PepalGarita-Cambarge and Rentsac-Moyerson-Langspring-Delphill-Blazon-Blackhall). These soil families correspond to some of the most highly elevated terrain in the basin, suggesting relatively little prehistoric use of these areas. Most of these elevated areas are located in the eastern part of the Green River Basin, where similarities to environmental factors at play in the Washakie Basin are probable.

In the Washakie Basin, site frequency is polarized between two groups of soil families. Sites are overrepresented in areas with the Wint-Westvaco-Teagulf-Tasselman-RogrubeHuguston-Haterton and Youjay-Westvaco-Monte-Kandaly-Haterton soil families, and underrepresented in all other soil families. The high frequency zone corresponds directly to soil families located in lower elevations. The low site frequency zone occurs with soils located on the elevated ridge and dissected plateau in the central part of the Washakie Basin area. These results directly confirm and support the results of the previously developed predictive model for the basin (Peebles 1983b).

The majority of the archaeological sites found in the WYCRO database for the Green River and Washakie Basins date to prehistoric time periods (Appendix C, Tables C-5 and C-6). This is not surprising given that there are roughly 12,000 years of prehistoric use of the area as compared with 250 years of historic use. The most common site type for both basins is identified as a prehistoric habitation site with hearths and fire-cracked rock, which is evidence of fire use and potentially food preparation (2,602 sites of this type occur in the Green River Basin and 148 sites occur in the Washakie Basin). The range of prehistoric sites includes general lithic scatters, burial sites, and prehistoric activity areas that have some subsurface features (i.e., hearths). There are also several site types associated with certain artifacts or features, including stone rings, cairns, petroglyphs, ground-stone tools, and locations where prehistoric pottery was found. Historic era sites include ranching sites, homesteads, open camps, cabins, mining, stage coach stations, and trash dumps. There are also linear features associated with the historic period such as historic trails, stagecoach lines, canals, and a freight road.

A site type in southwestern Wyoming that requires special mention is the secondary lithic procurement site. These sites cover large areas but have little to no subsurface manifestation. They occur as part of vast areas of desert pavement covered by residual lag cobbles of windpolished quartzite and chert. These materials are mostly poor quality toolstone, which was apparently suitable for use for some types of expedient tools. Debitage (mostly early stage core 
reduction debris) occurs among the fields of lag deposits, on the order of 1 artifact per 200 to $1,300 \mathrm{~m}^{2}$. Finished projectile points and features dateable by radiocarbon assay are not found within these secondary lithic procurement sites. Period of use typically cannot be established but is generally considered to have been occasional throughout the entire span of prehistory. In the combined Green River and Washakie Basins, there are roughly 700 sites of this type recorded, although many of these are parts of the same expansive cobble fields recorded separately by different investigators. In 2002, the Shute Creek-Whiskey Basin Archaeological Landscape was proposed in a portion of Lincoln County (48LN2444 IMAC Site Form 2002). This represents one of the first attempts to specifically address the secondary lithic procurement site type. BLM archaeologists in southwestern Wyoming have since defined at least two more "archaeological landscapes" to account for this site type. Identification and acknowledgement of this site type are to some degree important toward furthering an understanding of southwestern Wyoming prehistory, but the "landscapes" themselves are not considered eligible for NRHP listing. They are entirely surface manifestations without stratigraphic depth. They exhibit extremely thin artifact densities and cannot be dated. These sites provide evidence for the persistent, sporadic use of low-quality toolstone sources in local areas of desert pavement, but not much beyond that.

The NHPA only requires consideration of cultural resources that are eligible for listing on the NRHP. A determination of eligibility certifies that a resource has the potential to contribute to our understanding of the past. Determining whether an archaeological site is eligible usually requires limited excavations to determine if subsurface features are present. According to the WYCRO database within the Green River Basin, 1,795 sites have been determined eligible for listing, 3,212 sites have been determined ineligible, and 1,140 have yet to be evaluated (see Appendix C, Table C-7). In the Washakie Basin project area, there are 339 sites considered eligible, 319 considered ineligible, and 282 are unevaluated (see Appendix C, Table C-8).

A relatively small percentage of the known sites in southwestern Wyoming have undergone large-scale excavation. Archaeologists largely rely on the information from these excavated sites for their knowledge of specific cultural periods or phases. Many of these excavated sites have been mentioned above in the discussion on cultural chronology within the prehistoric context. Excavation is the best way to extract the information contained in these sites. The Blue Point site was a recent excavation that provided a considerable amount of information to the cultural chronology presented in Section 4.2.

The Blue Point site is a multicomponent site located in Sweetwater County in the Green River Basin. The site contains evidence of numerous cultural periods, including Paleoindian Alberta, terminal Paleoindian/Early Archaic, Early Archaic Great Divide, Late Archaic, and Late Prehistoric (Johnson and Pastor 2003). The site was found in 1983 as part of the Tg Soda Ash, Inc., Playa Project Tailing Pond \#3 Expansion project by Western Research Archaeology. The site was reexamined in 1996. Limited excavations took place in 1998, with more extensive excavations occurring in 1999 and 2000. The report from the 1999 and 2000 excavations was completed in 2004. The report and its finding serve as the most recent complete excavation record for the project area. The excavations shed light on the nature of Paleoindian lifeways in the Green River Basin and aid in understanding the climatic fluctuations and human adaptations during the late Paleoindian/Early Archaic period. 


\section{DATA GAPS, RESEARCH QUESTIONS AND PRIORITIES, AND MANAGEMENT RECOMMENDATIONS}

\subsection{COLORADO}

\subsubsection{Gaps in the Archaeological Record}

There are major gaps in the early prehistoric record of the Piceance Basin region. Very few sites from the Paleoindian Period have been identified in the region, and none have been excavated (Reed and Horn 1992:24). Simply stated, more Paleoindian sites need to be located before questions regarding subsistence, settlement, technology, and other aspects of early culture can be adequately addressed. Archaic Period sites are much better represented on the landscape, where they have been identified via projectile point styles and the occasional radiocarbon date from a surface-exposed feature. Beyond that, little information has been acquired from local Archaic sites, and empirical data regarding even basic subsistence practices are inadequate (Reed and Metcalf 1999:172).

The later part of prehistory in the Piceance Basin region is not much better known than the Paleoindian and Archaic Periods. Earlier hypotheses posited that Fremont-like horticulturalists avoided the Piceance Basin entirely (Spangler 2002:167). That supposition was based on the absence of Fremont rock art, rock/adobe architecture, and evidence for pit-houses. Instead, it was argued, Formative peoples continued an Archaic pattern of seasonal transhumance in which groups moved from winter camps in the lowlands to summer camps at higher elevations. The discovery of Fremont-like pottery at lowland sites on Piceance Creek required alteration of this settlement-subsistence model (Grady 1980). Subsequent work has confirmed some sort of Fremont presence in the Piceance Basin, but how that presence relates to existing regional Fremont variants (Uinta, San Rafael)—or whether it comprises some other cultural entity entirely—is still an open question (Reed and Horn 1992:26).

Most recently, Reed and Metcalf (1999:140-145) defined the Aspen Tradition. The definition accommodates the Formative hunter-gatherers in western Colorado who used pottery and the bow, and who grew corn, but who lacked other key characteristics of Fremont culture. It remains to be seen whether or not this new taxonomic construct will stand up under the scrutiny of other archaeologists working in the region.

Just to the west of the Piceance Basin, excavations of Fremont residential structures at Pedestal House, the Sandshadow site, and at other sites in the adjacent Douglas Creek drainage suggest the possibility of a somewhat different lifestyle on the margins of the Fremont cultural core area (Spangler 2002:181-182). The use of residences built of brush — rather than pit-houses or more substantial structures-indicates more ephemeral occupations. Residences on Douglas Creek appear to have been occupied by nuclear family households on a seasonal (summer-fall) basis and were mostly the setting for female-related activities. 
Evidence from Rimrock Hamlet in the Douglas Creek drainage shows a strong correlation between climatic changes and prehistoric subsistence adaptations (Spangler 2002:180-181). Horticulture at the site was practiced during a wet climatic cycle dating from A.D. 890 to 920 to A.D. 925 to 930 . Horticulture was then abandoned during a century-long dry period until about A.D. 1050 to 1065, when conditions improved again.

Back in the Piceance Basin, settlement modelers (Grady 1980:244-249; Newkirk and Roper 1983:157) argue that Fremont peoples could have left the lowlands in the spring after planting, then spent the summer and fall at higher elevations hunting deer and gathering piñon nuts before returning to the lowlands to harvest the corn crop and settle in for the winter. Such a pattern could still account for the site distribution pattern detected by recent survey work. On the Roan Plateau, other investigators argue that the few Fremont-like pottery sites are not Fremont and should be assigned to hunter-gatherers of the Aspen Tradition (Hoefer et al. 2002:92). Clearly, archaeological excavations need to be undertaken at valley bottom pottery-bearing sites in order to identify just exactly what Fremont peoples were doing in and around the Piceance Basin (Newkirk and Roper 1983:159).

Apparent differences between prehistoric cultural expressions at upland versus lowland camp sites on and around the Roan Plateau may be artificial. Hoefer et al. $(2002: 88,97)$ identify three factors that are involved. First, thick vegetation cover in upland areas may be limiting the discovery of features and artifacts that might otherwise be exposed at drier, less-vegetated lowland sites. This concern seems untenable for most upland areas in the Piceance Basin, where ground surface visibility is good despite the presence of piñon-juniper woodland where isolated artifacts and small lithic scatters are regularly detected and recorded. Second, lowland sites are located much closer to modern towns and ranches than are the more inaccessible upland sites. Hoefer et al. (2002) assert that collecting by artifact hunters and amateur archaeologists has, therefore, occurred more at lowland sites, and such activity can alter the composition of artifact assemblages. This may be true, but artifact predation has been documented at many upland sites as well. Third, most lowland areas are held under private ownership. Hoefer et al. (2002) note that this has resulted in disproportionately less survey coverage for those parts of the landscape and fewer reported sites. All these concerns may be immaterial when a fourth issue is considered, that is, the alluviation of lowland sites. Archaeologists in the Piceance Basin continue to assert that alluvial cutting and filling has either destroyed valley bottom sites or rendered them invisible to surface survey (Conner et al. 2004a:12), but such assertions have yet to be confirmed by any dedicated geomorphological studies.

Some researchers have noted the "old wood" problem associated with certain radiocarbon dates acquired from the region (Spangler 2002:183). Juniper trees are long-lived and may stand dead for centuries before being used as firewood. Once burned, such "old wood" will produce radiocarbon dates that are as much as 200 to 300 years older than the cultural features with which they are associated. This is a problem that cannot be ignored, and some studies are underway that are attempting to quantify corrections that may need to be applied (Reed and Metcalf 1999:151-152). In the meantime, it is vitally important that archeologists collect radiocarbon samples from the burnt remains of short-lived woody plants, such as sagebrush and greasewood, or attempt assays based on bone collagen. 


\subsubsection{Research Questions and Priorities}

The main thrust of problem-oriented archaeological research in the Piceance Basin has been directed toward an understanding of prehistoric economics. Since the peoples of the basin have apparently been hunter-gatherers throughout prehistory, research necessarily focuses upon identifying patterns of plant and animal resource exploitation, seasonal transhumance, food acquisition and processing technology, and so forth. Explanations for changes in these patterns are sought mainly in paleoclimatic fluctuations, which would have had major consequences for people tied so closely to the limited resources of a marginal environment.

In recent years, a partial explanation for prehistoric demographics in the Piceance Basin has been linked to toolstone resources (Conner et al. 2004a:13). Cryptocrystalline quartz materials (chert, chalcedony) occur rarely in the local bedrock deposits. In fact, no quarry sites have been identified in the Piceance Creek basin. These materials, however, still account for the vast quantity of all lithic assemblages found at basin sites. This indicates that prehistoric people in the Piceance Basin imported nearly all of their toolstone. Import of exotic toolstone has been documented in regard to obsidian (obtained from Wyoming and Idaho), "pumpkin" chert (from bedrock sources on the Yampa River), and other chert types originating from outside the basin. Some researchers have posited that the ephemeral occupations characteristic of most prehistoric sites in the Piceance Basin are, in part, due to the lack of local toolstone sources (Conner et al. 2004a:13).

The seminal survey work in the Piceance Basin region attempted to identify environmental factors responsible for the patterning of prehistoric site locations. Models developed by Hurlbett (1976) and Grady (1980) have had some success in this regard. These studies linked site locations with critical variables such as elevation, slope, aspect, and proximity to water and certain seasonally available plant and animal resources. Later modeling by Newkirk and Roper (1983) and Hoefer et al. (2002) confirmed the importance of these variables and refined earlier conclusions.

At least one later survey expanded upon earlier predictive models by positing specific research questions for prehistoric sites. Reed and Horn (1992) employed a broad, pan-regional perspective in developing research questions and criteria for site significance. For the most part, research questions were explicitly based upon an ecological approach that focused on human adaptation to the physical environment. Significant prehistoric sites with high research value were characterized as those that possessed physical integrity (i.e., intact, undisturbed cultural deposits), contained features (e.g., hearths, storage or habitation structures, and living surfaces), and that produced temporally or culturally diagnostic artifacts. Single-component prehistoric sites were also regarded as important cultural resources. Reed and Horn (1992:33-34) hypothesized that prehistoric sites found at elevations of 7,500 ft and above would produce more evidence of hunting and butchering activity than would lowland sites. As a corollary to this, they hypothesized that site size and complexity would decrease with increased elevation. They further hypothesized that sites would occur with higher than expected frequencies within $1 \mathrm{mi}$ of vegetation zone boundaries, noting the attraction generally attributed to ecotonal transition zones (Reed and Horn 1992:37). Addressing specific chronological questions, Reed and Horn (1992:36) posited that early and middle Paleoindian sites would be found exclusively along 
major river valleys or near the mouths of major tributary valleys. Numic sites in particular were hypothesized to decrease in size and complexity with increased elevation and would be characterized by higher than expected frequencies of obsidian artifacts (Reed and Horn 1992:39, 45).

Adopting a multiregional perspective, Pennefather-O'Brien et al. (1992:35-38) presented a series of less specific research topics for prehistoric sites. They considered the local prehistoric chronology inadequate, citing several unanswered questions, including (1) the date of the shift from Paleoindian to Archaic lifeways, (2) the presence or absence of Archaic pit-houses, (3) the nature of local paleoenvironmental conditions during the early and mid-Holocene, (4) the character of a McKean Complex cultural intrusion during the Middle Archaic, (5) the nature of the Archaic-Late Prehistoric transition, (6) the extent of Formative Fremont influence, (7) the viability of attributing most later Late Prehistoric components to Numic language speakers, (8) testing and refinement of the proposed historic Ute chronology, and (9) the identification of any historic period Indian sites at all. They stressed a need to employ detailed study of lithic assemblages to interpret site function and to trace lithic source areas, both of which are identified as critical research objectives. In addition, they identified subsistence analyses and inter- and intra-site patterning studies as important ways to determine site function and test models of prehistoric settlement systems.

The research design for the multicounty Entrega Gas pipeline laid out specific criteria to be considered in evaluating the contextual integrity of prehistoric and protohistoric sites (Redman and Chandler 2004:89). Sites with good integrity were identified as those that (1) occur on level or gently sloping ground, or on the lee side of a topographic rise; (2) include portions that occur outside of an erosional feature; (3) occur in a low-energy depositional environment with fine-grained sediments; (4) have at least 4 in. of sediment over bedrock; (5) have artifacts in association with features; (6) contain portions that are not disturbed by construction; and (7) possess either a single component or spatially segregated multiple components.

Larger and better-prepared survey reports through the 1990s (e.g., McPherson 1983; Reust 1993) continued to reference the earlier modeling efforts by Newkirk and Roper (1983) and Grady (1980). But increasingly, survey reports from the late 1990s to the present do not recognize previous models and make little effort to develop contexts for the evaluation of sites (e.g., Conner and Davenport 2001b). Most recent survey reports attach a boilerplate "criteria for evaluation" section that generically summarizes NRHP criteria and the evaluation process, but that rarely addresses specific regional research questions (e.g., Brown and Selle 2001). This practice occurs despite the well-developed earlier models and plentiful, occasionally updated mass of research questions presented in a few, larger survey reports (e.g., Pennefather-O'Brien et al. 1992; Redman and Chandler 2004; Reed and Horn 1992). Many of the smaller survey reports do happen upon sites with clear NRHP potential, but that are simply "field evaluated" without reference to existing research priorities.

In northwestern Colorado, this situation may be the result, to a large degree, of de facto historic preservation policy as implemented by local federal agency land managers. For example, a 1998 survey by Grand River Institute (1998b) for a transmission line in Rio Blanco County recorded two ridgetop prehistoric sites. The Grand River Institute archaeologists recommended 
evaluative testing at one of the sites (5RB3955) since it contained two surface-exposed hearths; a small scatter of burnt bone, lithics, and fire-cracked rock; and the remains of a wickiup (Grand River Institute 1998b:6). The other site (5RB3954) was composed of a small lithic scatter in an area of shallow soils disturbed by wind erosion, with no visible features and little potential for subsurface deposits. That site was field evaluated as "not eligible." However, Grand River Institute archaeologists stated that their recommendations meant little because "it is BLM policy to avoid all cultural resources despite their field evaluations and it is their clear intention to avoid all sites recorded by this project (Grand River Institute 1998b:9)." Thus it appears, in northwestern Colorado at least, that implementation of the NHPA by the BLM is resulting in the recording of previously undiscovered archaeological site locations, but little else beyond that. All archaeological sites are avoided, if possible. Sites rarely get test-excavated; those that do are the ones that cannot be avoided by development projects. As a result, understanding of regional prehistory remains perpetually stunted.

In a similar vein, recent site evaluation efforts have been cursory investigations not worthy of the resources represented (e.g., Conner and Davenport 2000; Harrison and Conner 2000). Evaluation efforts seem minimalist in nature, this despite a trend elsewhere in the region toward the use of larger excavation blocks (Reed and Metcalf 1999:169). Since 1980, no single site in the Piceance Basin has seen more than $3 \mathrm{~m}^{2}$ of excavation (see Table 2-1). Of the 11 sites test-excavated in the last 25 years, a total of less than $19 \mathrm{~m}^{2}$ has been opened up. Most field labor is concentrated upon simple mapping of surface finds. Excavation-when there is any-is focused on surface-exposed features, which are invariably shallow fire pits. These features almost always produce radiocarbon samples, paleobotanical samples, and faunal remains. Despite occasional disturbances, preservation of organic material is still extremely good (e.g., Harrison and Conner 2000:24). This fact has been repeatedly overlooked by investigators who equate shallow deposits, limited surface disturbance, or artifact predation with lack of physical integrity, and, therefore, write off a site as not eligible (Reed and Metcalf 1999: 178-179). Intrasite activity area patterning (i.e., camp layout) and its implications for duration and frequency of habitation; estimates of group size, sex, and age composition; and the character of domestic and other on-site activities is typically ignored. Large excavation blocks are necessary to fully expose shallowly buried sites with limited surface manifestations, small artifact assemblages, and lightly used activity areas. For decades, such plaza-style excavation units have been employed by archeologists working at shallow sites in other parts of the Intermountain West. This practice should be extended to include sites in northwestern Colorado.

Despite the rather intensive modeling effort over the last 30 years, the models have remained untested beyond simple comparisons between observed versus expected site frequency. No prehistoric site in the Piceance Basin has been intensively investigated. The floral, faunal, and chronological data needed to evaluate the models are certainly present, as evidenced by the few surface-exposed hearth features that have been sampled. But comprehensive data have not been collected and synthesized. Highland summer hunting camps have been posited, but whether these were base camps containing entire families, or ephemeral camps occupied solely by hunters is not known. Likewise, the function of upland camps, as compared with camps found in lowland settings, has not been empirically established, despite a dichotomy specifically proposed by the models. The kinds of animal and plant resources that were being exploited by people who lived in these camps has been hypothesized but not clearly demonstrated. Similarly, a seasonal 
round of subsistence has been suggested but still remains to be confirmed and dated on the basis of archaeological evidence (Hoefer et al. 2002:93-94).

The model developed by Grady (1980), especially, produced the picture of a culturally stagnant people inhabiting the Piceance Basin on a pan-millennial time scale. While the validity of the statistics and methods employed in that model cannot be seriously questioned, problems remain. Foremost of these is that sites from all time periods were lumped together in the analysis. As with most large-scale surveys, many sites could not be assigned to specific prehistoric periods because of the absence of diagnostic artifacts. The resulting analysis, however, ignores any temporal variation that might be present in the data. Undated prehistoric sites in the Piceance Basin-especially those used to develop Grady's model—need to be investigated more thoroughly to glean whatever chronological information they might contain. This is not unrealistic considering the excellent preservation of charcoal and other organic materials amenable to radiocarbon dating, even at open sites in this semiarid region.

Linked to the flawed synchronic perspective is the lack of consideration for paleoenvironmental change. Grady's model rather hopefully assumes that existing vegetation patterns extended well back into most of prehistory. It seems unrealistic to think that the boundaries and composition of vegetational ecozones did not change in response to the dramatic changes in climate that have accrued since the end of the Pleistocene. The absence of paleoclimatic studies from the Piceance Basin is cited as justification for making such an unfounded assumption. Clearly, paleoenvironmental reconstructions-based upon geomorphology, pollen, and/or phytolith sequences from stratified sites, and pack rat middens from paleontological contexts-need to generate the data by which ancient vegetation patterns may be better described (Newkirk and Roper 1983:159).

Another aspect of paleoenvironmental change involves landscape modification over time. Variability in erosion and alluviation is linked to climate change and has important ramifications for local archeology. In the Piceance Basin region, all surveys conducted to date, and the settlement models derived from them, are based upon the identification of artifacts exposed on the ground surface. The numbers and types of archaeological deposits buried in sand dunes, at the base of slopes, and in stream valley bottoms are completely unknown. This problem has direct implications for the study of the local Fremont presence, since Fremont settlements farther west in the Douglas Creek valley and Uinta Basin are known to be concentrated in valley bottoms. Researchers have also considered that the low number of Paleoindian and earlier Archaic sites found in the region may in part be due to deep burial of such sites in alluviated valley bottoms (Hoefer et al. 2002:27). Systematic geomorphological studies need to be undertaken in the larger Piceance Basin to address these problems (Hoefer et al. 2002:107; Newkirk and Roper 1983:159).

The absence of a good prehistoric chronology remains an important problem in the Piceance Basin region (Hofer et al. 2002:89, 92, 96). Despite a conscious effort to assign dates to sites in their modeling effort, Newkirk and Roper (1983:158-159) found this to be "extremely difficult" because of the "large mass of sites" that could not be dated. They complained that chronological data for the basin are "almost non-existent," and that any attempts to consider diachronic change would be hamstrung until a more adequate chronological framework becomes 
available. The situation has not changed much in the quarter-century that has gone by since that observation was made. Much of the problem rests with the Great Basin projectile point chronology itself, wherein stylistic types appear to have persisted unchanged for many thousands of years. Such conservative behavior speaks to the glacial pace of prehistoric cultural and technological change in the region, but does little to satisfy archaeologists' needs for succinct chronological markers.

The Formative in northwestern Colorado hardly differs from the preceding Archaic or subsequent Protohistoric Periods (Spangler 2002:186). Site locations, site frequency, artifact density, subsistence orientation, material culture, and so forth, are practically the same throughout. The nature of the Archaic-Formative transition is still poorly understood (Reed and Metcalf 1999:166). Evidence suggests that the main difference is the addition of pottery and changes in projectile point styles. The appearance of Rose Spring arrow points diagnostic of Fremont culture may not necessarily mark the introduction of bow and arrow hunting technology, and in any case, resulted in no discernable changes in the hunting practices of Archaic peoples in northwestern Colorado. Pottery presumably accompanied the introduction of horticulture. Fremont-like peoples apparently gave up horticulture during periods of climatic deterioration, retaining a dependence upon hunting and gathering. How the addition of corn may have affected an otherwise Archaic hunter-gatherer diet is not fully understood and needs to be researched (Reed and Metcalf 1999:166).

Archaeologists are still grappling with the problem of distinguishing Formative cultural expressions from the material culture of historic Ute peoples. Whether the Ute developed from local late prehistoric cultures or migrated into northwestern Colorado, supplanting earlier peoples, is still an open question. How Ute sites can be distinguished from the occupation sites of contemporaneous Shoshonean people is yet another problem that has not been resolved (Reed and Metcalf 1999:166-167). Conversely, the problem of distinguishing between briefly occupied historic Ute camps and later sheepherder, hunter, or cowboy camps has also been noted (Reed and Horn 1992:31). Did settlement systems change in protohistoric times after the adoption of the horse in the mid-1600s? Such questions are the subject of ongoing research in this region (Hoefer et al. 2002:93).

Resource Protection Planning Process documents developed for western Colorado help to identify significant cultural resources and provide a basis for generating research objectives for historic sites (Reed and Horn 1992:59). These documents are organized by theme, and sites that can be ascribed to a particular historic theme are generally regarded as possessing more research value than sites that cannot. The problem is that:

so little archaeological work has been conducted in Colorado . . . that no particular historic theme or subtheme from any historic period can be considered adequately investigated from an archaeological perspective. In fact, the majority of historic themes can be considered unexplored or, at best, in their infancy of investigation archaeologically (Reed and Horn 1992:59).

The upshot is that important historic archaeological sites in the Piceance Basin should be considered to be any sites that (1) are relatively undisturbed, (2) can be attributed to a specific 
theme, and (3) retain sufficient artifacts and features to permit further study (Reed and Horn 1992:59).

Exceptions to these criteria are the few, rare and unique historic sites that might be found in the basin. Examples include Cold War Era sites such as Site 5RB2307, the Rio Blanco Gas Stimulation Test Site (Reust 1993). This site is the last of three locations where the experimental use of underground nuclear blasts was employed to improve extraction of natural gas through Operation Plowshare in 1973. The program was one of the few peaceful uses of atomic bombs ever actually undertaken. The blast was marginally successful in causing natural gas to collect in the cavity and fissures produced by the bomb blasts; however, the gas was too radioactive to be sold commercially. The test site location is marked with a plaque and small monument.

Reed and Horn (1992:47-51) outline several specific research topics relevant to the study of historic period sites in the Piceance Basin. Their hypotheses include (1) ethnic affiliation of the inhabitants could be determined from the features and artifacts found at historic sites, (2) homesteading of marginal areas should date from circa 1890 to circa 1910, (3) the use of marginal agricultural areas and small mining operations should evidence a period of resurgence dating to the Great Depression era, (4) wagon roads were primitive roads or trails that should not evidence elaborate improvements or ancillary facilities, and (5) sites related to cattle ranching can be distinguished from those related to sheep ranching.

Hoefer et al. (2002:94-95) identify outstanding research questions regarding historic cultural resources in the Roan Plateau, and these can be extended to the larger Piceance Basin region as well. They stress that a basic chronology covering early Euroamerican settlement needs to be established. Research needs to examine how the physical isolation of the region affected economic conditions at local ranches and homesteads. How did this change with the arrival of the railroads? What is the evidence for early oil shale mining in the region? What can cabins and ranching sites tell us about the regional development of cattle and sheep raising over time, the ethnicity of ranchers and herders, socioeconomic conditions of ranching, and conflict between the cattle and sheep industries?

\subsection{UTAH}

\subsubsection{Gaps in the Archaeological Record}

Numerous gaps exist in the understanding of prehistory in the Uinta Basin. No comprehensive subsistence or settlement models have been developed for the Uinta Basin region as a whole (Spangler 2002:101). The prehistoric chronology is still considered inadequate. This problem has led to erroneous and speculative conclusions regarding the temporal and spatial range of prehistoric cultures (Spangler 2002:101). Multidisciplinary studies have been rare (Spangler 2002:101). Generally, institutional projects have failed to incorporate broader theoretical perspectives that attempt to explain the how and why of prehistoric adaptations (Spangler 2002:101). There is an apparent paucity of prehistoric sites on the south slope of the 
Uinta Mountains. This is perplexing since hunting-related sites are relatively common on the northern slope of the Uintas (Spangler 2002:142).

\subsubsection{Research Questions and Priorities}

Parts of the Circle Cliffs, White Canyon, and Tar Sand Triangle areas have not been wellstudied archaeologically; consequently, outstanding research questions are vast and range from general issues to specific problems. General questions involve basic chronology, the paleoenvironmental setting, and prehistoric subsistence, technology, settlement patterning, demographics, and cultural interactions. These and other, more specific research questions are presented in detail in the archaeological research plan for the Glen Canyon National Recreation Area (Geib et al. 1986:29-46).

Certain aspects of Archaic cultures have been well-documented but others have not. Excavations in local cave sites and rockshelters have produced good chronological information and excellent subsistence-related data. However, enclosed sites represent only a part of a presumed subsistence round. Data from open sites in a variety of topographic settings are also needed in order to acquire a fuller understanding of Archaic subsistence practices (Tipps 1988:18).

Basketmaker II sites appear to be absent from the Circle Cliffs and San Rafael Swell (Tipps 1988:19-23, 136). The reason for this is not readily apparent. Answers have not been generated by previous archaeological work in these regions.

The affiliation of Anasazi groups in White Canyon is currently a topic of debate (Tipps 1988:20,136). Research demonstrates that the canyon and its environs were intermittently occupied from the Basketmaker II through Pueblo III periods. Pueblo I and early Pueblo II sites are rare, but all sites dating to this time span appear to have been occupied by people possessing characteristics of both the Mesa Verde and Kayenta Anasazi. This problem of cultural overlap has not been resolved.

In the southern end of the San Rafael Swell and farther south into the Circle Cliffs area, archaeologists may have found evidence for Anasazi-Fremont interactions, but this has yet to be fully delineated because the cultural affiliation of specific sites has not been firmly established. There has been debate between researchers who assign sites to the Virgin or Kayenta Anasazi in the late Pueblo II/early Pueblo III period and those who assign these sites to Fremont occupations of the same time period (Tipps 1988:21-23, 136). This sort of situation is to be expected since the Circle Cliffs are located at the boundary between the San Rafael Fremont and Virgin and Kayenta Anasazi culture areas. 


\subsection{WYOMING}

\subsubsection{Southwestern Wyoming Archaeological Community}

Because of the extensive natural resources located in southwestern Wyoming and the preponderance of public lands, a considerable amount of archaeology has been undertaken in this region. The large amount of development has spawned a very active archaeological community. Most researchers have openly acknowledged the limitations in the current level of understanding of the prehistoric and historical processes operating in southwestern Wyoming. Most archaeological reports written for this area contain recommendations for future research. Other reports have been generated with the express purpose of identifying archaeological research issues for the region. For example, a 1995 technical report printed by the Department of Anthropology at the University of Wyoming specifically outlined the archaeological research issues for southwestern Wyoming (Larson 1996). The following sections summarize the primary research issues identified for the region as well as some of the key recommendations for the future of archaeology in southwestern Wyoming.

\subsubsection{Gaps in the Archaeological Record}

Sites recorded in southwestern Wyoming provide sufficient information for the basic chronology presented in Section 4.2. The major cultural time periods have been identified archaeologically; however, the processes that led to the changes between the various cultural periods are still being determined. Several key sites in Wyoming, such as the Wardell Site, Deluge Shelter, Deadman Wash, and Pine Spring, have yielded good stratified chronologies. These sites have been extrapolated as representative of the various cultural time periods. A considerable amount of evidence exists for some time periods, while evidence of others is extremely scarce. The reasons for this are unknown. To fill this gap, data recovery from components dating to the Paleoindian Period, and to the Great Divide, Pine Spring, Deadman Wash, and Firehole Phases should be prioritized (Thompson and Pastor 1995:145).

Data gaps for Paleoindian Period studies have been identified by Thompson and Pastor (1995:26-28). Evidence for pre-Clovis occupations in North and South America is beginning to become accepted among New World archaeologists. A pre-Clovis radiocarbon date has been confirmed for the deep component at Site 48SW5757 northwest of Green River (Reust et al. 1984:15). Strata that date between 23,000 and 10,000 B.C. need to be investigated for further evidence. Paleoindian components associated with the Clovis, Goshen, and Folsom complexes have not yet been investigated in the region, and are a definite research priority. Current understanding of Paleoindian subsistence may have been biased by the limited number and types of excavated Paleoindian sites reported in the region. More excavation and analysis need to be completed at other sites with known, but less intensively excavated Paleoindian components - most of which are habitations rather than kill/butchering sites. Synthetic studies of Paleoindian artifact styles, lithic reduction strategies, and toolstone use should be undertaken in an effort to better define Paleoindian cultural complexes and to identify cultural subgroupings, trade networks, and patterns of transhumance. 
Data gaps also exist for the Archaic Period (Thompson and Pastor 1995:40,46,50-51). The Great Divide Phase needs to be better-defined through data acquisition from the time period 6,500 to 4,300 B.C. The sort of habitation structures, diagnostic stone tools, and other technological attributes from this phase need to be more firmly established. Data regarding plant resource exploitation (macrofossils, pollen washes, and phytolith studies) need to be collected for the Opal and Pine Spring Phases. Existing models of Archaic settlement patterning need to be tested. More paleoclimatic reconstruction needs to be undertaken to confirm or modify earlier work that was based almost entirely on sediment analysis. Dated pollen sequences are especially needed.

Adequate methods for discovering deeply buried prehistoric sites in southwestern Wyoming need to be developed. Such sites include Archaic pit-houses, which have typically been exposed accidentally during machine excavations at previously investigated sites thought to contain only surface or shallow cultural deposits in sand dunes (Larson 1997:354). Deeply buried sites are also known in alluvial settings. For example, the Ten Mile Draw Site contains two stratified cultural horizons buried under more than $3 \mathrm{~m}$ of alluvium, and was only discovered because these horizons were exposed in an eroded cutbank on an arroyo wall (Sall et al. 1983). Colluvial deposits can bury archaeological sites as well. The Deadman Wash Site contained more than $2 \mathrm{~m}$ of stratified deposits buried in mixed eolian and colluvial deposits near the base of a sloping valley wall. The site would not have been found if the most recent Late Prehistoric component had not been partially exposed on the site surface (Armitage et al. 1982).

Methods for site discovery via deep sampling are part of standard archaeological practice elsewhere in North America and should be employed in Wyoming. Archeologists should not only be trained in these techniques, but should be able to recognize landscape settings where such techniques need to be employed (Larson 1996:75-76). Shovel testing routinely samples sediments up to $28 \mathrm{in}$. below ground surface, and the use of a posthole digger extends this to $1 \mathrm{~m}$. Hand-operated 6 to 8 -in. diameter bucket augers are routinely employed to sample deposits up to $2 \mathrm{~m}$ below ground surface. These hand-operated tools enable exploration of most dunal and colluvial deposits. Exploration in deeper deposits, especially in alluvial settings, may require the use of hydraulic coring machines that can obtain sediment cores to depths of $5 \mathrm{~m}$ or more. Typically, deep coring is undertaken as part of a structured investigation designed to locate buried surfaces where human habitation could have been possible. Small-diameter cores typically reveal humic-stained culturally altered sediments rather than individual artifacts, although the recovery of debitage, pottery, shell, and bone is not unknown. Use of these methods should be required in all areas where deeply buried archaeological deposits are possible. Reconstructions of prehistoric settlement systems will remain flawed as long as the data from deeply buried sites is incomplete.

\subsubsection{Research Questions and Recommendations}

The following are several research questions and recommendations for the southwestern Wyoming area. The discussion presents issues that have been identified by several researchers from the region. 


\subsubsection{Research Questions and Priorities}

Future research questions relate to clarifying the cultural chronologies and examining how and why the aspects that define the various cultural periods developed (Larson 1996:21). Chronological subdivisions on the "complex" and "phase" level need to be refined. A synthesis needs to be undertaken linking material culture traits to these temporal-cultural subdivisions. Results from radiocarbon assays and other absolute dating methods (thermoluminescence, dendrochronology, tephrachronology, etc.) need to be corrected, standardized, and synthesized on a regional scale. The relationship between prehistoric population dynamics and climatic change is not well understood. Do cultural periods correlate with climatic changes or periods of climatic stability? Several models have been proposed to explain these changes, but the relative lack of excavation at good stratified sites makes understanding difficult.

A host of research questions revolves around the topic of lithic technology (Larson 1996:61-62). Where are the source locations for specific toolstone types within the region? Outside the region? How do relative frequencies of exotic toolstone types vary over time? What types of stone tools are being reused and what types are used expediently? Aside from projectile points, are there other kinds of stone tools that can be employed as chronological indicators? Were ground-stone tools used for purposes other than seed grinding?

Specific to the Late Prehistoric period are questions related to ceramic technology (Larson 1996:49). What is the origin of pottery in southwestern Wyoming? How did the use of ceramics spread across the region over time? Were vessels imported or manufactured locally? Do ceramic types found in southwestern Wyoming fit within known categories from outside the region, or is a local typology necessary?

Research questions should focus on the transition periods and whether continuity in populations can be determined for southwestern Wyoming (Peebles et al. 1983a:166). McKean culture groups from the northwestern High Plains have been tentatively identified in the Wyoming Basin during the Middle Archaic. Groups using projectile point styles and subsistence technology typical of the Great Basin are thought to have been in southwestern Wyoming during arid periods (Larson 1996:30). It is not known if the cultures identified in the region are the result of sole occupation of the area or if they were groups that utilized the region seasonally or on a longer-term basis as climate change would allow. Studies involving ceramics should examine whether the evidence of the Fremont culture in southwestern Wyoming is the result of population relocation or technological diffusion. It is currently not known what mechanism was at work during this period.

While sampling surveys undertaken in southwestern Wyoming have been able to predict prehistoric site locations with some degree of accuracy, the meaning of site distribution has yet to be explained. Settlement pattern models have been developed, but need to be tested (Peebles et al. 1983a:166). Models need to explain patterns of site clustering in certain topographic locales in addition to relating subsistence orientation, seasonality, and site function. Such models, of course, need to be framed using a diachronic perspective. 
The body of data on prehistoric subsistence needs to be augmented and synthesized (Larson 1996:25,27,52,55). When and to what extent does an increased dependence on floral resources in subsistence occur? This change in resource use is thought to begin with the Archaic Period, but the timing and correlation with environmental and cultural change is not well defined. Is the increased use of ground-stone tools in later periods evidence of increased reliance on seed and other floral resources? Similarly, how did the process work during the transition from big game hunting in Paleoindian times, to the reliance on small game animals and seed /root collecting in the Early Archaic (Johnson and Pastor 2003)?

Feature functions should also be examined (Larson 1996:58). Slab-lined hearths are a feature type that is poorly understood. Most date to the Archaic, but the spatial distribution (on a regional scale) and functions of this feature type (on all scales) are not well defined (Larson1996:27; Thompson and Pastor 1995). These pits seem to be related to wild plant food processing but this is not entirely clear.

Pit-houses are a common feature from the Opal Phase of the Early Archaic, and others are known from the Late Prehistoric. The function of these features is still not clearly understood, nor is it known with certainty during what seasons they were used (Harrelet al. 1997; Larson 1996:43-44; Larson 1997; Waitkus and Eckles 1997). How pit-houses figured into the subsistence-settlement systems of supposed highly mobile Archaic hunter-gatherers is a question that needs to be answered. The technological and cultural relationships that may have existed between Archaic pit-house forms and later ones from the Late Prehistoric Uinta Phase are also not known (Larson 1996:31; Johnson and Pastor 2003).

Paleodemographic changes are still poorly documented for southwestern Wyoming, despite a growing body of data (Larson 1996; Peebles et al. 1983a:166,b:146). Changes along the scale from high mobility to more sedentism are often assumed or quantified in general terms, but need to be linked to specific evidence for subsistence, seasonality, and site layout. Radiocarbon date totals have been employed as a proxy to suggest relative population fluctuations (e.g., Thompson and Pastor 1995:30-32), but sequenced data from stratified sites have not been forthcoming. Some stratified sites contain gaps in occupational sequences, but whether these can be attributed to real population changes, depletion of local resources, changing cultural factors involved in site selection, or other reasons has yet to be fully investigated.

Rock art sites are poorly understood in southwestern Wyoming, and many questions regarding them remain to be answered (Larson 1996:72). Most of these questions require synthesis rather than additional fieldwork. For example, how do rock art locations correlate with topographic features? How do local rock art traditions relate to stylistic traditions defined elsewhere in the Rocky Mountain region? How can input from Native Americans be used to interpret the meaning of rock art images? How old is rock art in southwestern Wyoming?

More intensive investigation is needed at historic sites in southwestern Wyoming (Peebles et al. 1983a:165-166,b:147). In this regard, documentary research, informant interviews, and artifact analyses are considered more necessary than excavations per se. The recent assessment of the Cherokee Trail and the Bryan to Browns Park Wagon Road in the vicinity of Flaming Gorge Reservoir by Gardner et al. (2006) is an excellent example of the type of valuable 
contribution that basic documentary research can provide. However, the exact routes of various historic trails through the Green River Basin need to be defined through field inspections. Functional differences among, and ethnic associations of, livestock surveillance camps, cairns, and other remains of ranching-related features need to be clarified. Types, dates, and locations of historic mining activities need to be systematically documented.

The Wyoming SHPO has outlined several historic context priorities for the state (Wyoming SHPO 2004). The themes for these contexts relate to cultural resources that are considered most at risk because of conflicts with development, demolition, and other land uses. Four of these themes are relevant to historic cultural resources in the Green River and Washakie Basins and can be considered priorities for historical archaeology in these areas. The Southern Wyoming Transportation Corridor Context stresses the importance of trails, wagon roads, stage stations, abandoned railroad grades and bridges, railroad section and labor camps, and segments of the Lincoln Highway. The Wyoming Hardrock and Softrock Mining Context identifies abandoned coal, trona, and uranium mines as significant historic sites, as well as associated features such as mining towns, mills, rail spurs, etc. The Oil Industry Historic Context identifies important early oil extraction sites and facilities such as hand-dug wells, drill sites (including tool hearths and springpole, cable tool, rotary, and portable rigs), jack pumps and beam-pumps, gas plants and gas processing sites, electrification systems, oil and gas storage sites, squatter camps, field camps, and company towns (Massey 1992). The Homesteading, Ranching, and Stock Grazing in Southwest Wyoming Context focuses on the remnants of homesteads and ranch houses, along with all related facilities. These facilities include structures like outbuildings, windmills and stock tanks, fences, corrals, and cairns; and features such as graves and cemeteries, and line camps and sheepherder camps.

\subsubsection{Recommendations}

Past archaeological research suggests that deep trenching could be a more effective means of identifying sites. The amount of erosion experienced in the Wyoming Basin has buried many sites deeper than is effectively detected through surface surveys or shovel testing (Thompson and Pastor 1995).

Site mapping should focus on landforms more so than just the site components. Site reports should continue to describe the environmental setting, including the landforms present.

The locations of sand dunes have been found to overlap to a great extent with prehistoric site locations. This is especially true in the Washakie Basin (Peebles et al. 1983b:146). But the presence of sand dunes in any given tract, however, is not always readily discernable from standard topographic maps. The locations of dune fields should be identified from existing satellite imagery and/or stereo air photographs. Dune locations should be digitized from these sources and transferred as overlays onto digitized USGS quadrangle maps to provide highresolution "at a glance" sensitivity maps (Peebles et al. 1983b:140-150).

More consistent terminology is needed to ensure that everyone is referring to the same cultural materials to facilitate comparisons and possible modeling. Typical approaches are strict 
encoding and standardized report formats; however, these approaches have their own set of issues.

Testing should not necessarily be confined to the area of potential effect (APE). If the main part of a significant site that is being impacted by a project is outside of the APE, there are circumstances when the entire site should be tested (Thompson and Pastor 1995).

\subsection{MANAGEMENT RECOMMENDATIONS}

Throughout this document, recommendations have been made regarding changes needed in current practices and for consideration in the development of Resource Management Plans for the study area. These recommendations were derived from background research in compliance reports, other Class I Overviews, predictive modeling efforts, and published summaries of regional archeology. Other recommendations have been developed subsequent to conversations with BLM and SHPO archaeologists. A summary of these recommendations follows. No specific criteria were identified through this study to better evaluate site significance; however, implementation of several of the recommendations identified below could potentially lead to an improved set of criteria. The following discussion also touches on appropriate management actions for certain types of known sites.

\subsubsection{Regional Synthesis of CRM Data}

The foremost need across the study area is for synthesis of the archaeological work that has been conducted in the last several decades. This is especially true in the Piceance Basin, where known deeply stratified sites are rare, and archaeological work at such sites is even rarer. In the Piceance Basin — and to some extent in the Uinta and Washakie Basins as well — the nature and timing of prehistoric cultural developments will need to be pieced together after numerous small, single component sites are investigated. Unless a special research project is undertaken, such sites will necessarily be investigated individually over the course of several years as the result of development-related compliance work. Synthesis will be needed to fit data from these small sites into the larger picture.

Limited attempts at data synthesis appear occasionally in the larger Class III survey reports. These reports, however, have been mostly prepared for large pipeline projects that cross several subregions; therefore, conclusions have been fairly superficial and more like summaries of previous work rather than true synthetic works. Existing Class I reports tend to stress CRM concerns and summarize previous work rather than synthesize it. One exception is the recent publication by Spangler (2002) covering the Uinta Basin and northeastern Utah in general. Another is People of the Sage, a very useful BLM-sponsored synthetic study for the western Wyoming Basin (Thompson and Pastor 1995). The Context for the Northern Colorado River Basin, funded by the Colorado Historical Society and produced by the Colorado Council of Professional Archaeologists (Reed and Metcalf 1999), also contains good synthetic work, but its inclusion of the entire western third of Colorado necessarily reduces the focus on the Piceance Basin. The BLM should periodically sponsor and publish works of this nature for all regions 
within its purvey, otherwise the data generated by day-to-day archaeological compliance work accumulate but do not get synthesized and disseminated. Up-to-date syntheses of the results of prehistoric and historic archaeological work in northwestern Colorado and southwestern Wyoming are overdue.

The scope of the current project is too wide to allow for a detailed analysis of the data from the Piceance Basin. In order to conduct the current study, surveys from the three basins were only sampled in order to meet project constraints. A focused study of an individual basin would be more appropriate for conducting a comprehensive regional synthesis.

\subsubsection{Significance of Small Sites}

Small sites represent the overwhelming mass of prehistoric archeological remains across the study area. Typically, such sites contain evidence for short-term habitation and localized subsistence activity by small groups of people. Owing to dry conditions, such sites will typically produce preserved organic material suitable for radiocarbon dating and faunal and floral analysis. Individually, such sites may not seem imposing, but collectively small sites contain a wealth of archaeological data. This fact must always be considered when the NRHP status of small sites is being assessed.

A program of excavations at selected small sites should be undertaken to develop locally derived data on prehistoric lifeways. This is most needed in the Piceance Basin, but knowledge of prehistory in the Uinta and Washakie Basins could also benefit from such a program. This work could be undertaken in the context of a program of assessing NRHP eligibility of the many sites that "need data," or that have been casually "field recommended" as NRHP eligible.

\subsubsection{Paleoenvironmental Reconstruction of Prehistoric Climate Change}

Paleoenvironmental research (pollen, phytolith, macrobotanical, and sediment analysis) needs to be undertaken in the Uinta and Piceance Basins, and to a lesser degree in southwestern Wyoming. Numerous reports and research designs outline the critical need for such studies. The BLM should sponsor laboratory analysis of existing, unexamined samples from stratified sites. Such studies should be required for all future data recovery work at prehistoric sites where there is good potential for deep, dated, stratified profiles.

\subsubsection{Geomorphological Context and Deeply Buried Site Discovery}

More geomorphological work needs to be undertaken in conjunction with archaeological investigations. The archaeological community in southwestern Wyoming has already acknowledged and to some degree addressed this need. Except for a few large pipeline projects, however, little such work has appeared in CRM reports from northeastern Utah and northwestern Colorado. This is unfortunate, since so many sites in those regions are buried in sand dunes, the stratigraphic development of which has received little study. Likewise, despite continued 
assertions that large prehistoric sites may be buried in valley bottoms, practically no geomorphological work has been undertaken in alluvial settings in these regions. The BLM should sponsor comprehensive programs of geomorphological investigations designed to address these issues in the Uinta and Piceance Basins.

In a related vein, standard techniques for locating buried archaeological sites need to be regularly employed by archaeologists working in the entire study area. While many or most sites will be at least partially visible on the ground surface because of erosion, some will still be completely buried and therefore undetectable via pedestrian reconnaissance. The BLM should require that (1) shovel testing be undertaken in locations where the potential exists for cultural deposits to be buried up to 28 in. below surface, (2) hand augering be undertaken in locations where deposits may be buried up to $2 \mathrm{~m}$; and (3) a program of coring be undertaken where a more deeply buried potential exists. Deeply buried cultural deposits almost always retain their physical integrity and are, therefore, more likely to be eligible for listing on the NRHP. Such sites should not be overlooked.

\subsubsection{Site Management Priorities}

Of the several site types present across the study area, rock shelters and wickiup camps require the most management by the BLM in the form of monitoring and protective measures. Human burials, although rarely exposed or discovered, may require mitigation or protective measures. Such work will necessitate consultation with particular tribes to determine affiliation and appropriate treatment. All other types of sites will continue to require careful documentation. Most will need to be protected from erosion, wildfire, and human impacts, but the appropriate management will need to be determined for each site on an individual basis.

Sites with the remains of wickiup structures are threatened by a variety of factors (mostly human). Current management practices should be altered to protect the resource. Consideration should be given to (1) adequately inventorying all wickiup sites, (2) rerouting or closing roads and trails that pass near these sites, (3) posting signage, (4) monitoring known sites, and (5) suspending the practice of "chaining" in the vicinity of these sites.

\subsubsection{Use Categories}

The BLM requested that this report contain recommended use categories for known sites. The information examined in this study does not support the development of use categories. 


\section{REFERENCES}

Agenbroad, L.D., 1990, "Before the Anasazi: Early Man on the Colorado Plateau," Plateau 61(2), Museum of Northern Arizona, Flagstaff, Ariz.

Aikens, C.M., 1983, “The Far West,” in Ancient North Americans, 2nd ed., W.H. Freeman and Company, New York, N.Y.

Aikens, C.M., and D.B. Madsen, 1986, "Prehistory of the Eastern Area," in Handbook of North American Indians, Vol. 11, Great Basin, W.L. d'Azevedo (editor), W.C. Sturtevant (general editor), Smithsonian Institution, Washington, D.C.

Ambler, J.R., 1970, "Fremont Culture: Restatement of Some Problems," American Antiquity 37(1):61-66.

Armitage, C.L., et al., 1982, The Deadman Wash Site, Cultural Resource Management Report 6, Archaeological Services-Western Wyoming College, Rock Springs, Wyo.

Athearn, F.J., 1982, An Isolated Empire: A History of Northwestern Colorado, Cultural Resources Series No. 2, Colorado State Office of the Bureau of Land Management, U.S. Department of the Interior, Denver, Colo.

Baker, S., et al., 2002, Archaeological Inventory of Abandoned Mines in the Circle Cliffs Area, Garfield County, Utah, Brigham Young University Museum of Peoples and Cultures Technical Series 02-07, Office of Public Archaeology, Brigham Young University, Provo, Utah.

Bengston, G., 2007, Argonne National Laboratory, unpublished information.

Berry, M.S., and C.F. Berry, 1975, An Inventory and Evaluation of Cultural Resources in and around Oil-Shale Lease Areas $U-a$ and $U-b$, Antiquities Section, Division of State History, Salt Lake City, Utah.

BLM (Bureau of Land Management), 1983, Final Supplemental Environmental Impact Statement for the Prototype Oil Shale Leasing Program, Colorado State Office, Denver, Colo., Jan.

BLM, 1984, Utah Combined Hydrocarbon Leasing Regional Final EIS: Volume I: Regional Analyses, Richfield District Office, Richfield, Utah, June.

BLM, 1987, Grand Junction Resource Area, Resource Management Plan and Record of Decision, Grand Junction District, Colo., Jan.

BLM, 1988, Record of Decision and Resource Management Plan, Glenwood Springs Resource Area, Grand Junction District, Colo., June. 
BLM, 2004a, Final Environmental Impact Statement for the Jack Morrow Hills Coordinated Activity Plan/Proposed Green River Resource Management Plan Amendment, Wyoming State Office, Rock Springs Field Office, Wyo., July.

BLM 2004b, Cultural Resources Class I Regional Overview for the Kemmerer Planning Area, Wyoming, Kemmerer Field Office, Wyo., Aug.

BLM, 2004c, Draft Roan Plateau Resource Management Plan Amendment and Environmental Impact Statement, Colorado State Office, Glenwood Springs Field Office, Colo., Nov.

BLM, 2006, Roan Plateau Planning Area, Including Former Naval Oil Shale Reserves Numbers 1 \& 3, Resource Management Plan Amendment \& Environmental Impact Statement, Colorado State Office, Aug.

BLM, 2007, Oil Shale and Tar Sands Resource Management Plan Amendments to Address Land Use Allocations in Colorado, Utah, and Wyoming and Programmatic Environmental Impact Statement, Draft, prepared by Argonne National Laboratory, Argonne, Ill., Dec.

Brown, J., and M. Selle, 2001, A Cultural Resource Inventory of Selected Areas in the Piceance Basin: A Sample Inventory of 1207 Acres in Rio Blanco County, Colorado, Bureau of Land Management, White River Field Office, Meeker, Colo.

Callaway, D. et al., 1986, "Ute," pp. 336-367 in Handbook of North American Indians, Vol. 11, Great Basin, W.L. d'Azevedo (editor), W.C. Sturtevant (general editor), Smithsonian Institution, Washington, D.C.

Cashion, W.B., 1967, Geology and Fuel Resources of the Green River Formation, Southeastern Uinta Basin, Utah and Colorado, U.S. Geological Survey, Professional Paper 548.

Chapman, S.S., et al., 2004, Ecoregions of Wyoming, U.S. Geological Survey, Reston, Va.

Chapman, S.S., et al., 2006, Ecoregions of Colorado, U.S. Geological Survey, Reston, Va.

Coltrain, J., 1994, “The Steinaker Gap Burials and Their Implications for Farming along the Basin/Plateau Rim: A Stable Carbon and Radio-Isotope Study," pp. 138-148 in Steinaker Gap; An Early Fremont Agricultural Farmstead, R.K. Talbot and Lane D. Richens, Museum of Peoples and Cultures Technical Series No. 94-18, Brigham Young University, Provo, Utah.

Conetah, F.A., 1982, A History of the Northern Ute People, K.L. MacKay and F.A. O'Neil (editors), Uintah-Ouray Tribe, Salt Lake City, Utah.

Conner, C.E., 2006a, Class III Cultural Resource Inventory of a 160-Acre Block Area for the Chevron Research, Development, and Demonstration Oil Shale Project in Rio Blanco County, Colorado, prepared by Grand River Institute, Grand Junction, Colo., for Bureau of Land Management, White River Field Office. 
Conner, C.E., 2006b, Class III Cultural Resource Inventory of a Linear ROW (7150) for the Chevron Research, Development, and Demonstration Oil Shale Project in Rio Blanco County, Colorado, prepared by Grand River Institute, Grand Junction, Colo., for Bureau of Land Management, White River Field Office.

Conner, C.E., and B.J. Davenport, 2000, Report of Evaluative Test Excavations at Site $5 R$ RB51 in Rio Blanco County, Colorado, GRI Project No. 2005, Grand River Institute, Grand Junction, Colo.

Conner, C.E., and B.J. Davenport, 2001a, Class III Cultural Resource Inventory Report for the Proposed Land Exchange in Rio Blanco County, Colorado, for Shell Frontier Oil and Gas, Inc., GRI Project No. 2060, Grand River Institute, Grand Junction, Colo.

Conner, C.E., and B.J. Davenport, 2001b, Class III Cultural Resource Inventory Report for the Privately Held Portions of a Proposed Land Exchange in Rio Blanco County, Colorado, for Shell Oil and Gas, Inc., prepared by Grand River Institute, Grand Junction, Colo., for Bureau of Land Management, White River Field Office.

Conner, C.E., and B.J. Davenport, 2001c, Addendum, Class III Cultural Resource Inventory Report for the BLM Portions of a Proposed Land Exchange in Rio Blanco County, Colorado, for Shell Oil and Gas, Inc., prepared by Grand River Institute, Grand Junction, Colo., for Bureau of Land Management, White River Field Office.

Conner, C.E., and B.J. Davenport, 2005, Class III Cultural Resource Inventory Report for Six Proposed Reroutes of the EnCana Meeker Pipeline in Rio Blanco County, Colorado, for Trigon EPC, GRI Project No. 2518, Grand River Institute, Grand Junction, Colo.

Conner, C.E., and D.L. Langdon, 1983, Union Oil Parachute Creek Shale Oil Program, Phase I -Cultural Resources Study, prepared by Grand River Institute, Grand Junction, Colo., for Union Oil Company of California.

Conner, C.E., et al., 1998, Class III Cultural Resource Inventory Report for the Yankee Gulch Sodium Minerals Project Lease Area West of Piceance Creek in Rio Blanco County, Colorado, for American Soda, L.L.P, GRI Project No. 9815, Grand River Institute, Grand Junction, Colo.

Conner, C.E., et al., 2004a, A Class III Cultural Resources Inventory for the Proposed Ryan Gulch Gathering System and Compressor Station in Rio Blanco County, Colorado, for Williams Production RMT Company, GRI Project No. 2449, Grand River Institute, Grand Junction, Colo.

Conner, C.E., et al., 2004b, 2004 Experimental Project Site: A Class III Cultural Resources Inventory Report for a 920-Acre Block in Rio Blanco County, Colorado, for Shell Oil and Gas, prepared by Grand River Institute, Grand Junction, Colo., for Bureau of Land Management, White River Field Office. 
Conner, C.E., et al., 2005a, 2005 Experimental Project Site: A Class III Cultural Resources Inventory Report for 448 Block Acres in Rio Blanco County, Colorado, for Shell Oil and Gas, prepared by Grand River Institute, Grand Junction, Colo., for Bureau of Land Management, White River Field Office.

Conner, C.E., et al., 2005b, Piceance Basin Study: A Class III Cultural Resources Inventory of Six Proposed Drill Holes and Related Access Routes in Rio Blanco County, Colorado, prepared by Grand River Institute, Grand Junction, Colo., for Shell Frontier Oil and Gas and the White River Resource Area - Craig District, Bureau of Land Management, U.S. Department of Interior, Meeker, Colo.

Cordell, L.S., 1995, Ancient Pueblo Peoples: Exploring the Ancient World, Smithsonian Books, Washington, D.C.

Cordell, L.S., 1997, Archaeology of the Southwest, Academic Press, New York, N.Y.

Creasman, S.D., 1987, "The Altithermal: Paleoenvironmental Reconstruction and Subsistence Change in Southwestern Wyoming," pp. 283-297 in Perspectives on Archaeological Resources Management in the Great Plains, A.J. Osborn and R.C. Hassler (editors), I \& O Publishing, Omaha, Nebr.

Creasman, S.D., et al., 1990, "Prehistoric Pottery of Southwest Wyoming: A Preliminary Assessment," paper presented at the 48th Annual Plains Anthropological Conference, Oklahoma City, Okla.

Crouse, H.Y., 1954, “A Folsom Point from the Uinta Basin, Utah,” Masterkey 28(1):50-51.

Darnell, N., 2006, Class III Cultural Resource Inventory Report of a 160-Acre Block Area for the 2nd Generation ICP Site in Rio Blanco County, Colorado, for Shell Frontier Oil and Gas, prepared by Grand River Institute, Grand Junction, Colo., Bureau of Land Management, White River Field Office.

DOI (U.S. Department of the Interior), 1973, Final Environmental Statement for the Prototype Oil Shale Leasing Program, Volume IV of VI, Consultation and Coordination with Others, Washington, D.C.

Duncan, C., 2000, “The Northern Utes of Utah," pp. 167-224 in A History of Utah's American Indians, F.S. Cuch, (editor), Utah State Division of Indian Affairs/Utah State Division of History, Salt Lake City, Utah.

Feeney, D., et al., 2004, Big Game Migration Corridors in Wyoming, University of Wyoming, Wyoming Open Spaces Initiative, Laramie, Wyo. Available at http://www.uwyo.edu/ openspaces/docs/MigrationCorridors.pdf. Accessed April 24, 2006. 
Ferguson, T.J., 1997, "Hopi Reconnaissance of the Carlota Copper Project: Ethnohistoric Overview and Cultural Concerns," manuscript on file at SWCA, Inc., Environmental Consultants, Salt Lake City, Utah.

Ferguson, T.J., 2003, Ethnographic Study of Ten Tribes: Cultural Affiliation of the Uinta and Great Salt Lake Variant of Fremont in Utah. Anthropological Research, L.L.C., Tucson, Arizona.

Frison, G.C., 1978, Prehistoric Hunters of the High Plains, 1st ed., Academic Press, New York, N.Y.

Frison, G.C., 1991, Prehistoric Hunters of the High Plains, 2nd ed., Academic Press, New York, N.Y.

Frison, G.C., and M. Kornfeld, 1995, Interim Report on the 1994 Testing, Data Recovery, and Analysis at Three Paleoindian Sites in Grand County, Colorado, and Summary of Current Investigations, Technical Report No. 6b, Department of Anthropology, University of Wyoming, Laramie, Wyo.

Gardner, A.D., and V.R. Flores, 1989, Forgotten Frontier: A History of Wyoming Coal Mining, Westview Press, Inc., Boulder, Colo.

Gardner, A.D., et al., 2006, Historical Assessment of the Cherokee Trail and Bryan to Browns Park Road in Sweetwater County, Western Archaeological Services, Rock Springs, Wyo.

Geib, P.R., et al., 1986, Archaeological Research Plan for the Glen Canyon National Recreation Area, Northern Arizona University Archaeological Report 998, prepared by the Archaeology Laboratory, Department of Anthropology, Northern Arizona University, Flagstaff, Ariz., for the National Park Service, Rocky Mountain Regional Office, Denver, Colo.

Grady, J., 1980, Environmental Factors in Archaeological Site Locations, Piceance Basin, Colorado, Cultural Resource Series 9, Bureau of Land Management, Colorado State Office, Denver, Colo.

Grady, J., 1984, Northwest Colorado Prehistoric Context, Colorado Historical Society, Denver, Colo.

Grand River Institute, 1994, Class III Cultural Resource Inventory Report on the Proposed Piceance-to-Parachute Pipeline in Garfield and Rio Blanco Counties, Colorado, prepared by Grand River Institute, Grand Junction, Colo., for Barrett Resources, Inc., Parachute, Colo.

Grand River Institute, 1998a, Report on the Class III Cultural Resources Inventory of the UNOCAL/BLM \& N.O.S.R. Land Exchange in Garfield County, Colorado, for UNOCAL Corporation Diversified Business Group, prepared by Grand River Institute, Grand Junction, Colo., for Bureau of Land Management, Craig District Office, 
Grand River Institute, 1998b, Class III Cultural Resource Inventory Report for Phase I of a Proposed 138-kV Transmission Line in Piceance Creek Area of Rio Blanco County, Colorado for White River Electric Association, GRI Project No. 9816, Grand River Institute, Grand Junction, Colo.

Greenberg, M.E., 2006, EGL Oil Shale Tract Powerline, Class III Inventory, Rio Blanco County, Colorado, prepared by Cultural Resource Analysts, Inc., Longmont, Colo., for O\&G Environmental Consulting, Englewood, Colo.

Harrell, L.L., et al., 1997, "Archaic Housepits in the Wyoming Basin," pp. 334-366 in Changing Perspectives of the Archaic on the Northwest Plains and Rocky Mountains, M.L. Larson and J.E. Francis (editors), University of South Dakota Press, Vermillion, S.D.

Harrison, C., and C. Conner, 2000, Evaluative Test Excavations at Sites 5RB446, 5RB3955, 5RB3956, and 5RB3989 in Rio Blanco County, Colorado, GRI Project No. 9952, Grand River Institute, Grand Junction, Colo.

Hauck, F.R., et al., 1979, Final Report of the Natural Buttes Cultural Mitigation Study, Archeological-Environmental Research Corporation Paper 13, Salt Lake City, Utah.

Hoefer, T., and M.E. Greenberg, 2006, A Class III Cultural Resource Inventory of the Proposed EGL Oil Shale Development Tract, Rio Blanco County, Colorado, prepared by Cultural Resource Analysts, Inc., Longmont, Colo., for O\&G Environmental Consulting, Englewood, Colo.

Hoefer, T., et al., 2002, Class I Cultural Resource Overview of the Roan Plateau Management Area, Garfield County, Colorado, prepared by RMC Consultants, Inc., Lakewood, Colo., for Bureau of Land Management, Colorado State Office and Glenwood Springs Field Office.

Hurlbett, R.E., 1976, Environmental Constraint and Settlement Predictability, Northwestern Colorado, Cultural Resource Series 3, Bureau of Land Management, Colorado State Office, Denver, Colo.

Husband, M.B., 1984, Colorado Plateau Country Historic Context, Colorado Historical Society, Office of Archaeology and Historic Preservation, Denver, Colo.

Irwin, H.T., 1971, "Developments in Early Man Studies in Western North America, 1969-1970," in Papers from a Symposium on Early Man in North America, New Developments: 1960-1970, R. Shutler Jr. (editor), Arctic Anthropology 8(2), Madison, Wisc.

Irwin-Williams, C., and C.V. Haynes, 1970, "Climatic Change and Early Population Dynamics in the Southwestern United States," Quaternary Research 1:59-71.

Jennings, J.D., 1956, “The American Southwest: A Problem in Cultural Isolation,” pp. 59-127 in Seminars in Archaeology: 1955, R. Wauchope (editor), Memoirs of the Society for American Archaeology No. 11, Washington, D.C. 
Jennings, J.D., 1978, Prehistory of Utah and the Eastern Great Basin, University of Utah Anthropological Papers No. 98, University of Utah Press, Salt Lake City, Utah.

Jennings, J.D., 1986, "Prehistory: Introduction," pp. 113-119 in Handbook of North American Indians, Vol. 11, Great Basin, W.L. d'Azevedo (editor), W.C. Sturtevant (general editor), Smithsonian Institution, Washington, D.C.

Jennings, J.D., 1989, Prehistory of North America, Mayfield Publishing Company, Mountain View, Calif.

Johnson, D., and J. Pastor, 2003, The Blue Point Site: Paleo-Indian/Archaic Transition in Southwest Wyoming, prepared for FMC Corporation, Western Archaeological Services, Rock Springs, Wyo.

Kelly, I.T., and C.S. Fowler, 1986, "Southern Paiute," pp. 368-397 in Handbook of North American Indians, Vol. 11, Great Basin, W.L. d'Azevedo (editor), W.C. Sturtevant (general editor), Smithsonian Institution, Washington, D.C.

Lamb, S.M., 1958, "Linguistic Prehistory of the Great Basin,” International Journal of Linguistics 24(2):95-100.

LaPoint, H.J., et al., 1981, Archaeological Investigations in the Canyon Pintado Historic District, Rio Blanco County, Colorado, Phase I-Inventory and Test Excavations, Reports of the Laboratory of Public Archaeology 53, Colorado State University, Fort Collins, Colo.

Larralde, S.L., and S.M. Chandler, 1981, Archaeological Inventory in the Seep Ridge Cultural Study Tract, Uintah County, Utah, Cultural Resource Series 11, Bureau of Land Management, Utah State Office, Salt Lake City, Utah.

Larralde, S.L., and P.R. Nickens, 1980, "Archaeological Inventory in the Red Wash Study Tract, Uintah County, Utah," in Sample Inventories of Oil \& Gas Fields in Eastern Utah 1978-1979, P.R. Nickens (editor), Cultural Resource Series 5, Bureau of Land Management, Utah State Office, Salt Lake City, Utah.

Larson, M.L., 1996, Archaeological Research Issues in Southwestern Wyoming, Technical Report No.12, Department of Anthropology, University of Wyoming.

Larson, M.L., 1997, "Housepits and Mobile Hunter-Gatherers: A Consideration of the Wyoming Evidence," Plains Anthropologist 42-161:353-369.

Leach, L.L., 1970, “Archaeological Investigations at Deluge Shelter in Dinosaur Monument," Ph.D. dissertation, Department of Anthropology, University of Colorado, Boulder, Colo.

Lindsay, L.W., 1976, "Unusual or Enigmatic Stone Artifacts: Pots, Pipes, Points and Pendants from Utah," Antiquities Section Selected Papers 2(8):107-117. 
Lipe, W.D., 1980, "The Southwest," in Ancient North Americans, J.D. Jennings (editor), W.H. Freeman Company, New York, N.Y.

Madsen, D.B., 1979, "The Fremont and the Sevier: Defining Prehistoric Agriculturalists North of the Anasazi," American Antiquity 44(4):711-722.

Madsen, D.B., and S.R. Simms, 1998, "The Fremont Complex: A Behavioral Perspective," Journal of World Prehistory 12(3):255-336.

Marwitt, J.P., 1970, Median Village and Fremont Culture Regional Variation, University of Utah Anthropological Papers No. 95, Salt Lake City, Utah.

Marwitt, J.P., 1986, "Fremont Cultures," pp. 161-172 in Handbook of North American Indians, Vol. 11, Great Basin, W.L. d'Azevedo (editor), W.C. Sturtevant (general editor), Smithsonian Institution, Washington, D.C.

Mason, J.P., and K.A. Miller, 2005, Water Resources of Sweetwater County, Wyoming, Report 2004-5214, U.S. Department of the Interior, U.S. Geological Survey, Scientific Investigations, Reston, Va.

Massey, R., 1992, Oil Industry: Historic and Historic Archeological Context, Wyoming State Historic Preservation Office, Cheyenne, Wyo.

McKibbin, A., 1992, The Questar North-South Pipeline: Final Report on Archaeological Investigations, manuscript on file, Bureau of Land Management, Vernal, Utah.

McNees, L.M., et al., 1992, Class III Cultural Resource Inventory and Test Excavations for the Northwest Pipeline System Expansion Project, Segments 21, 22, and 23, Lincoln County, Wyoming, prepared for Northwest Pipeline Company, Salt Lake City, Utah, report submitted to the Wyoming Bureau of Land Management, Mariah Associates, Laramie, Wyo.

McPherson, P.J., 1983, Piceance Basin Archaeology: A Class III Cultural Resource Inventory of Federal Oil Shale Lease Tract C-A, Rio Blanco County, Colorado, U.S. Department of the Interior, Bureau of Land Management.

Mehls, S.F., 1982, The Valley of Opportunity: A History of West-Central Colorado, Cultural Resources Series No. 12, Colorado State Office of the Bureau of Land Management, U.S. Department of the Interior, Denver, Colo.

Metcalf, M.D., 1987, "Contributions to the Prehistoric Chronology of the Wyoming Basin," pp. 233-261 in Perspectives on Archaeological Resources Management in the Great Plains, A.J. Osborn and R.C. Hassler (editors), I \& O Publishing Company, Omaha, Nebr.

Metcalf, M.D., et al., 1989, A Class III Cultural Resource Inventory of the Proposed Questar North-South Pipeline, Daggett and Uintah Counties, Utah, prepared by Metcalf Archaeological Consultants, Inc., Eagle, Colo., for Questar Pipeline Company, Salt Lake City, Utah, Jan. 
Montgomery, K.R., and M.S. Wolfe, 2000, Cultural Resource Inventory of Coastal Oil and Gas Corporation's Yellow Creek Four Well Locations, Rio Blanco County, Colorado, prepared by Montgomery Archaeological Consultants, Moab, Utah, for Bureau of Land Management, White River Resource Area, Craig District.

Morss, N., 1931, "The Ancient Culture of the Fremont River in Utah," Peabody Museum of American Archaeology and Ethnology 12(3), Cambridge, Mass.

Murphey, P.C., and D. Daitch, 2007, Paleontological Overview of Oil Shale and Tar Sands Areas in Colorado, Utah, and Wyoming, Feb.

Murphy, R.F., and Y. Murphy, 1986, "Southern Shoshone and Bannock,” pp. 284-307 in Handbook of North American Indians, Vol. 11, Great Basin, W.L. d'Azevedo (editor), W.C. Sturtevant (general editor), Smithsonian Institution, Washington, D.C.

Newkirk, J.A., and D.C. Roper, 1983, Predictive Modeling in the Piceance Basin, Northwest Colorado. Prepared by Gilbert/Commonwealth, Englewood, Colo., for U.S. Department of the Interior, Bureau of Land Management, Craig District, White River Resource Area.

Newkirk, J.A., and L.H. Bambrey, 1983, A Cultural Resources Survey for the Pacific Shale Project Environmental Baseline Study, prepared by Gilbert/Commonwealth Englewood, Colo., for Camp Dresser and McKee, Inc., Wheat Ridge, Colo.

Norman, V.G., and F.R. Hauck, 1980, Final Report on the MAPCO River Bend Cultural Mitigation Study, Archeological-Environmental Research Corporation Paper 18, Salt Lake City, Utah.

Peebles, T.C., et al., 1983a, A Class II Cultural Resource Survey of the Green River Study Area, Sweetwater County, Wyoming, prepared for U.S. Department of Interior, Bureau of Land Management.

Peebles, T.C., et al., 1983b, A Class II Cultural Resource Survey of the Washakie Basin Study Area, Sweetwater County, Wyoming, prepared for U.S. Department of Interior, Bureau of Land Management.

Pennefather-O'Brien, E., et al., 1992, Colorado Interstate Gas Company Uinta Basin Lateral 20" Pipeline: Class III Cultural Resource Final Report, Utah, Colorado, and Wyoming, Metcalf Archaeological Consultants, Inc., Eagle, Colo.

Pitblado, B.L., 1994, "Paleoindian Presence in Southwest Colorado," Southwestern Lore 60 (4) 1-20.

Price, P.J., 1978, Archaeological Reconnaissance of the Proposed Superior Oil Company Land Exchange, Rio Blanco County, Colorado, Reports of the Laboratory of Public Archaeology, No. 21, Laboratory of Public Archaeology, Colorado State University, Fort Collins, Colo. 
Redman, K., and S.M. Chandler, 2004, Class III Cultural Resource Inventory of the Colorado Segments of the Planned Entrega Gas Pipeline, Rio Blanco, Moffat, Larimer and Weld Counties, Colorado, Alpine Archaeological Consultants, Inc., Montrose, Colo.

Reed, A.D., 1988, Ute Cultural Chronology, Archaeology of the Eastern Ute: A Symposium, P.R. Nickens (editor), Colorado Council of Professional Archaeologists Occasional Papers No. 1, Mesa College, Grand Junction, Colo.

Reed, A.D., and J.C. Horn, 1992, Cultural Resource Inventory of the Planned Transcolorado Natural Gas Pipeline, Western Colorado and Northwestern New Mexico: A Report of the 1991 Field Season, Alpine Archaeological Consultants, Inc., Montrose, Colo.

Reed, A.D., and M.D. Metcalf, 1999, Colorado Prehistory: A Context for the Northern Colorado River Basin, Colorado Council of Professional Archaeologists, Denver, Colo.

Reed, A.D., and P.R. Nickens, 1980, The Cisco Cultural Resource Study: a Sample-Oriented Inventory, East-Central Utah, in Sample Inventories of Oil \& Gas Fields in Eastern Utah 1978-1979, P.R. Nickens (editor), Cultural Resource Series 5, Bureau of Land Management, Utah State Office, Salt Lake City, Utah.

Reust, T., et al., 1984, Archeological Site Testing of the Texasgulf Playa No. 3 Tailings Pond Expansion Project, Western Research Archeology, Rock Springs, Wyo.

Reust, T.P., 1993, A Class III Cultural Resources Survey of the U.S. Department of Energy Rio Blanco Gas Stimulation Test Site, Rio Blanco County, Colorado, Mariah Associates, Inc., Albuquerque, N.M.

Roehler, H.W., 1992, Description and Correlation of Eocene Rocks in Stratigraphic Reference Sections for the Green River and Washakie Basins, Southwest Wyoming, U.S. Geological Survey, Professional Paper 1506.

Roessel, R.A., 1983, Dinétah: Navajo History, Vol. II. Navajo Curriculum Center and Title IV-B Materials Development Project, Rough Rock Demonstration School, Rough Rock, Arizona.

Rosenberg, R.G., 1984, Historic Overview and Trail Evaluation for the Exxon-Larbarge Project, Lincoln and Sublette Counties, Wyoming, Cultural Research and Management, Inc. Cheyenne, Wyo.

Sall, J.E., et al., 1983, "Recent Excavations in the Northwestern Plains and Northeastern Great Basin," Western Prehistoric Research Archeological Monograph 3:91-94.

Schirer, D.L., 1994, "Fort Duchesne," in Utah History Encyclopedia, A.K. Powell (editor), University of Utah Press, Salt Lake City, Utah. 
Shimkin, D.B., 1947, "Wind River Shoshone Ethnogeograph,” University of California Anthropological Records 5(4), Berkeley, Calif.

Shimkin, D.B., 1986, "Eastern Shoshone," pp. 308-335 in Handbook of North American Indians, Vol. 11, Great Basin, W.L. d'Azevedo (editor), W.C. Sturtevant (general editor), Smithsonian Institution, Washington, D.C.

Spangler, J., 2002, Paradigms and Perspectives Revisited, prepared by Uinta Research for the Bureau of Land Management, Vernal District, Vernal, Utah.

Spangler, J.D., 1993, "Site Distribution and Settlement Patterns in Lower Nine Mile Canyon: The Brigham Young University Surveys of 1989-91," Master's thesis, Brigham Young University, Provo, Utah.

Stainbrook, 1999, Open Trench Inspection and Testing Results for the Mountain Gas Resources, Lizardhead 3-28 Pipeline, Sublette County, Wyoming, Archaeological Services, Western Wyoming College, Rock Springs, Wyo.

Steigers Corporation, 1999, Cultural Resources Treatment Plan for the Yankee Gulch Sodium Minerals Project, Steigers Corporation, Englewood, Colo.

Steward, J.H., 1997, Basin-Plateau Aboriginal Sociopolitical Groups, reprint, University of Utah Press, Salt Lake City, Utah, originally printed in 1938, Smithsonian Institution Bureau of American Ethnology Bulletin 120, United States Government Printing Office, Washington, D.C.

Thompson, K.W., and J.V. Pastor, 1995, People of the Sage: 10,000 Years of Occupation in Southwest Wyoming, Archaeological Services, Western Wyoming Community College.

Thompson, P.J., 1993, "Excavations in Nine Mile Canyon from 1892-1990: A Study in Cultural Diversity," Master's thesis, Brigham Young University, Provo, Utah.

Thompson, R.A., 1979, A Stratified Random Sample of the Cultural Resources in the Canyonlands Section of the Moab District, Cultural Resource Series 1, Bureau of Land Management, Utah State Office, Salt Lake City, Utah.

Tickner, P.A., et al., 1996, Final Report of the Cultural Resource Inventory of Naval Oil Shale Reserve Lands, Garfield County, Colorado, prepared by Alpine Archaeological Consultants, Inc., Montrose, Colo., for U.S. Department of Energy.

Tipps, B.L., 1988, The Tar Sands Project: An Inventory and Predictive Model for Central and Southern Utah, Cultural Resource Series 22, Bureau of Land Management, Utah State Office, Salt Lake City, Utah.

Tom, G., and R. Holt, 2000, “The Paiute Tribe of Utah,” pp. 225-263 in A History of Utah's American Indians, F.S. Cuch (editor), Utah State Division of Indian Affairs/Utah State Division of History, Salt Lake City, Utah. 
Topper, R., et al., 2003, Ground Water Atlas of Colorado, Colorado Geological Survey, Special Publication 53, Denver, Colo.

Tripp, G.W., 1966, “A Clovis Point from Central Utah,” American Antiquity 31(3):435-436.

Truesdale, J.A., 1989, "Archaeological Investigations along the Echo Park Road, Dinosaur National Monument, Moffat County, Colorado," manuscript on file, Dinosaur National Monument, Dinosaur, Colo.

Truesdale, J.A., 1990, “Archaeological Investigations of the Uinta Basin Fremont in Dinosaur National Monument (1988-1990)," paper presented at the 48th Plains Anthropological Conference, Norman, Okla.

Waitkus, B., and D.G. Eckles, 1997, "Semi-subterranean Pithouse Structures in Wyoming," pp. 307-334 in Changing Perspectives of the Archaic on the Northwest Plains and Rocky Mountains, M.L. Larson and J.E. Francis (editors), University of South Dakota Press, Vermillion, S.D.

Weber, D.A., et al., 1977, Archaeological Reconnaissance of Nine In Situ Oil Shale Lease Tracts, Colorado-Utah, Reports of the Laboratory of Public Archaeology No. 3, Laboratory of Public Archaeology, Colorado State University, Fort Collins, Colo.

Wilde, J.D., 1992, A Class III Cultural Resource Inventory of Bureau of Reclamation Lands Adjacent to the Seedskadee National Wildlife Refuge, Sweetwater County, Wyoming, Brigham Young University Museum of Peoples and Cultures Technical Series 91-16, Brigham Young University, Provo, Utah.

Woods, A.J., et al., 2001, Ecoregions of Utah, U.S. Geological Survey, Reston, Va.

Wormington, H.M., 1955, "A Reappraisal of the Fremont Culture," in Proceedings of the Denver Museum of Natural History No. 1, Denver, Colo.

Wyoming SHPO, 2004, Historic Context Development Plan for Wyoming, Wyoming State Historic Preservation Office, Cheyenne, Wyo. Available at http://wyoshpo.state.wy.us.

Young, R.K., 1997, The Ute Indians of Colorado in the Twentieth Century, University of Oklahoma Press, Norman, Okla.

Zier, C.J., et al., 1983, Cultural Resources Technical Report for the Riley Ridge Environmental Impact Statement, prepared by Metcalf-Zier Archaeologists, Inc., Eagle, Colo., for U.S. Department of the Interior, Bureau of Land Management, and U.S. Department of Agriculture, Forest Service.

Zier, C. J., and D.A. Jepson, 1991, Test Excavation of Three Prehistoric Sites in the Marathon Land Exchange, Lower Piceance Creek Area, Rio Blanco County, Colo., prepared for Colorado Division of Wildlife, Denver, Colo. 